This document was prepared in conjunction with work accomplished under Contract No. DE-AC09-96SR18500 with the U. S. Department of Energy.

\title{
DISCLAIMER
}

This report was prepared as an account of work sponsored by an agency of the United States Government. Neither the United States Government nor any agency thereof, nor any of their employees, nor any of their contractors, subcontractors or their employees, makes any warranty, express or implied, or assumes any legal liability or responsibility for the accuracy, completeness, or any third party's use or the results of such use of any information, apparatus, product, or process disclosed, or represents that its use would not infringe privately owned rights. Reference herein to any specific commercial product, process, or service by trade name, trademark, manufacturer, or otherwise, does not necessarily constitute or imply its endorsement, recommendation, or favoring by the United States Government or any agency thereof or its contractors or subcontractors. The views and opinions of authors expressed herein do not necessarily state or reflect those of the United States Government or any agency thereof. 


\section{REVIEW OF CATALYTIC HYDROGEN GENERATION IN THE DEFENSE WASTE PROCESSING FACILITY (DWPF) CHEMICAL PROCESSING CELL (U)}

D. C. Koopman

December 2004

Immobilization Technology Section Savannah River National Laboratory Aiken, SC 29808

Prepared for the U.S. Department of Energy Under Contract Number DEAC09-96SR18500

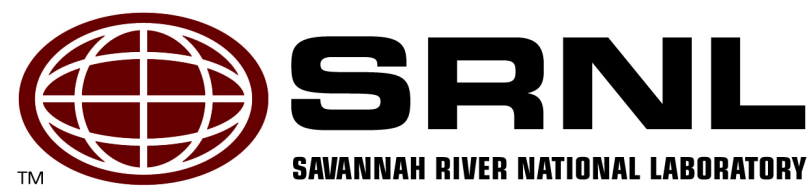




\section{DISCLAIMER}

This report was prepared by Westinghouse Savannah River Company (WSRC) for the United States Department of Energy under Contract No. DE-AC09-96SR18500 and is an account of work performed under that contract. Neither the United States Department of Energy, nor WSRC, nor any of their employees makes any warranty, expressed or implied, or assumes any legal liability or responsibility for the accuracy, completeness, or usefulness, of any information, apparatus, or product or process disclosed herein or represents that its use will not infringe privately owned rights. Reference herein to any specific commercial product, process, or service by trademark, name, manufacturer or otherwise does not necessarily constitute or imply endorsement, recommendation, or favoring of same by WSRC or by the United States Government or any agency thereof. The views and opinions of the authors expressed herein do not necessarily state or reflect those of the United States Government or any agency thereof.

\section{Printed in the United States of America}

Prepared For

U.S. Department of Energy 
Key Words: $D W P F, C P C$, sludge, hydrogen, noble metals, SRAT, SME, simulant, Shielded Cells

Retention: Permanent

\section{REVIEW OF CATALYTIC HYDROGEN GENERATION IN THE DEFENSE WASTE PROCESSING FACILITY (DWPF) CHEMICAL PROCESSING CELL (U)}

D. C. Koopman

December 2004

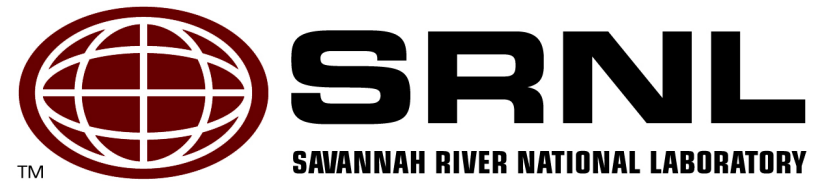




\section{REVIEWS AND APPROVALS}

\section{AUTHOR:}

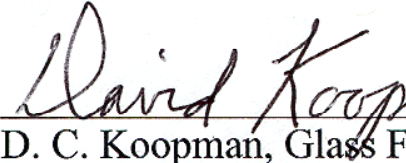

D. C. Koopman, Glass Formulation \& Process Development

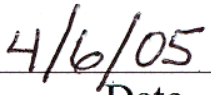

\section{TECHNICAL REVIEWERS:}

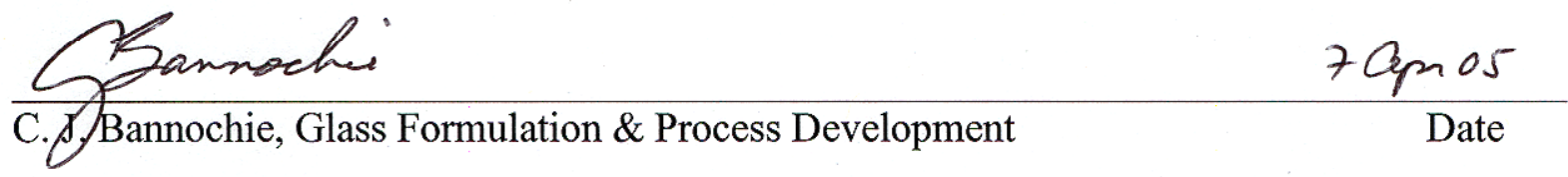

\section{APPROVERS:}

En freetzhen

E. W. Holtzscheiter, Manager, Immobilization Technology Section

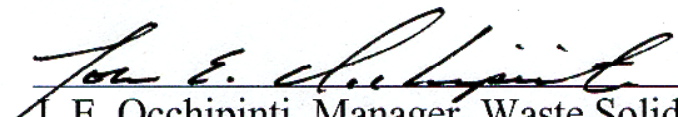




\section{EXECUTIVE SUMMARY}

This report was prepared to fulfill the Phase I deliverable for HLW/DWPF/TTR-98-0018, Rev. 2, "Hydrogen Generation in the DWPF Chemical Processing Cell", 6/4/2001. The primary objective for the preliminary phase of the hydrogen generation study was to complete a review of past data on hydrogen generation and to prepare a summary of the findings. The understanding was that the focus should be on catalytic hydrogen generation, not on hydrogen generation by radiolysis. The secondary objective was to develop scope for follow-up experimental and analytical work.

The majority of this report provides a summary of past hydrogen generation work with radioactive and simulated Savannah River Site (SRS) waste sludges. The report also includes some work done with Hanford waste sludges and simulants. The review extends to idealized systems containing no sludge, such as solutions of sodium formate and formic acid doped with a noble metal catalyst. This includes general information from the literature, as well as the focused study done by the University of Georgia for the SRS.

The various studies had a number of points of universal agreement. For example, noble metals, such as $\mathrm{Pd}, \mathrm{Rh}$, and $\mathrm{Ru}$, catalyze hydrogen generation from formic acid and formate ions, and more acid leads to more hydrogen generation. There were also some points of disagreement between different sources on a few topics such as the impact of mercury on the noble metal catalysts and the identity of the most active catalyst species. Finally, there were some issues of potential interest to SRS that apparently have not been systematically studied, e.g. the role of nitrite ion in catalyst activation and reactivity.

The review includes studies covering the period from about 1924-2002, or from before the discovery of hydrogen generation during simulant sludge processing in 1988 through the Shielded Cells qualification testing for Sludge Batch 2. The review of prior studies is followed by a discussion of proposed experimental work, additional data analysis, and future modeling programs. These proposals have led to recent investigations into the mercury issue and the effect of co-precipitating noble metals which will be documented in two separate reports. SRS hydrogen generation work since 2002 will also be collected and summarized in a future report on the effect of noble metal-sludge matrix interactions on hydrogen generation. Other potential factors for experimental investigation include sludge composition variations related to both the washing process and to the insoluble species with particular attention given to the role of silver and to improving the understanding of the interaction of nitrite ion with the noble metals. 
WSRC-TR-2002-00034

Revision 0

This page intentionally left blank. 


\section{TABLE OF CONTENTS}

EXECUTIVE SUMMARY

iii

LIST OF TABLES

vii

LIST OF ACRONYMS

viii

1.0 Introduction

2.0 Review of Past Work

2.1 Off-site Studies on General Systems

2.1.1 Bond, G. C. [1962]

2.1.2 Müller and Loerpabel [1929]

2.1.3 Ruthven and Upadhye [1971]

2.1.4 Smith and Ortman [1984]

2.1.5 Hill and Winterbottom [1988]

2.1.6 Wiemers [1988]

2.1.7 Langowski et al. [1996]

2.1.8 Wiemers, Langowski, et al. [1996]

2.1.9 Wet Oxidation of Formic Acid

SRTC Work Reviewed (Next Five Sections)

2.3 Simulant Work by C.W. Hsu et al.

2.3.1 WSRC-RP-90-664

2.3.2 SRL-PTD-90-0082

2.3.3 WSRC-MS-92-270

2.3.3.1 Commentary on 2.3.1 and 2.3.2 and 2.3.3 11

2.3.4 WSRC-RP-92-1194

2.3.5 WSRC-RP-92-1213

2.3.6 WSRC-RP-92-1236

2.3.7 WSRC-TR-94-0513

2.3.7.1 Commentary on 2.3.4, 2.3.5, 2.3.6 and 2.3.7 17

2.4 Work at the University of Georgia by King et al. 17

2.4.1 Report 1 - March $1991 \quad 18$

2.4.2 Report 2 - April $1991 \quad 18$

2.4.3 Report 3 - May $1991 \quad 18$

2.4.4 Report 4 - June 1991, Rev. 0 and Rev. 1

2.4.5 Report 5 - July $1991 \quad 19$

2.4.6 Report 6 - August $1991 \quad 20$

2.4.7 Report 7 - September $1991 \quad 20$

2.4.8 Report 8 - October $1991 \quad 20$

2.4.9 Report 9 - November $1991 \quad 21$

2.4.10 Report 10 - December $1991 \quad 21$

2.4.11 Report 11 - January $1992 \quad 21$

2.4.12 PNL Slide Presentation - July 7, 1992

2.4.13 Chemical Pretreatment of Nuclear Waste, (King et al.) 22

2.4.14 Inorganica Chimica Acta, 237, 1995 (King and Bhattacharyya) 22

2.4.15 Env. Sci. and Tech., 30, 1996 (King, Bhattacharyya, and Wiemers) 22

2.4.16 Env. Sci. and Tech., 31, 1997 (King, Bhattacharyya, Smith, and Wiemers) 23 
2.4.17 Env. Sci. and Tech., 32, 1998 (King, Bhattacharyya, Smith, and Wiemers) 23

2.4.17.1 Commentary on Relevant UGa Findings 23

2.5 Simulant Work in IDMS 24

2.5.1 Commentary on IDMS Hydrogen Data 28

2.6 Shielded Cells Testing 28

2.6.1 Program One, $1991 \quad 29$

2.6.2 Program Two, 1992

2.6.3 Interim Tests 36

2.6.4 Sludge Batch 1A (Macrobatch One) 36

2.6.5 Sludge Batch 1B (Macrobatch Two) 37

2.6.6 Sludge Batch 2 (Macrobatch Three) 37

2.6.7 Commentary on Shielded Cells Testing 38

2.7 Sludge Batch Supporting Simulant Studies 39

2.7.1 Sludge Batch 1A 39

2.7.2 Sludge Batch 1B $\quad 40$

2.7.3 Lambert and Boley - unpublished 41

2.7.4 WSRC-TR-99-00111 41

2.7.5 Preparation of Melter Feed Containing CST 42

2.7.6 Sludge Batch $2 \quad 43$

2.7.7 Commentary on Sludge Batch Simulant Tests 46

3.0 Conclusions 47

4.0 Recommendations/Path Forward 51

$\begin{array}{ll}5.0 \text { References } & 56\end{array}$ 


\section{LIST OF TABLES}

Table 1 - Mercury and Noble Metal Bases for DWPF Sludges ............................................ 8

Table 2 - Noble Metal Basis for 1990 Hsu Scoping Work ................................................ 9

Table 3 - Revised Noble Metal Basis for Hsu Simulant Tests ........................................... 10

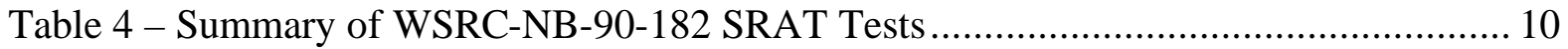

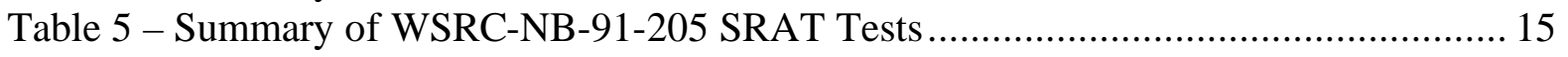

Table 6 - Summary of WSRC-NB-92-99 SRAT Tests........................................................ 16

Table 7 - IDMS Run Summary ................................................................................. 25

Table 8 - Changing Noble Metal Bases During IDMS Campaigns, wt. \% Dry ..................... 26

Table 9 - Noble Metals, Mercury, and Nitrite in Selected IDMS Runs................................ 26

Table 10 - Peak Hydrogen, Nitrite, and Acid Additions ...................................................... 27

Table 11 - Sludge Compositions for Two of the Sludges Used in 1991 Tests...................... 30

Table 12 - Small Scale SRAT Tests With Simulants in 773-A, 1991 .................................... 31

Table 13 - Small Scale SRAT Tests With Real Waste in 773-A, 1991 ................................ 32

Table 14 - Sludge Compositions for the Sludges Used in 1992 Tests.................................. 33

Table 15 - Small Scale SRAT Tests of the Late Wash/Nitric Acid Flowsheet ...................... 34

Table 16 - Noble Metals in Macrobatch Confirmation Tests............................................... 38

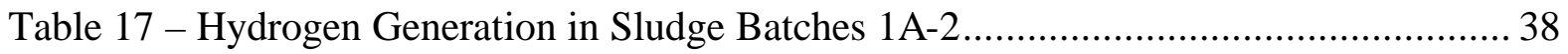

Table 18 - Mercury and Noble Metals in Tank 51 Tests ...................................................... 39

Table 19 - Tank 42 Sludge-Only Process Development Noble Metals .................................. 40

Table 20 - Tank 42 Simulant Bench-Scale Hydrogen Generation Data ................................ 41

Table 21 - Large Batch Run Summary at DWPF Scale ................................................... 42

Table 22 - SRAT/SME Hydrogen Generation Rates for Tank 42 ..................................... 42

Table 23 - SRAT/SME Simulations for the CST Salt Alternative ..................................... 43

Table 24 - Alternative Salt Process Simulations at Baseline Conditions............................... 43

Table 25 - Noble Metals in Sludge Batch 2 Simulant Tests ................................................ 44

Table 26 - Hydrogen Generation for Tank 40 SRAT Tests ................................................ 44

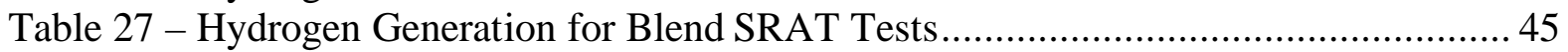

Table 28 - Macrobatch 3 SME Cycle Hydrogen Generation .............................................. 45 


\section{LIST OF ACRONYMS}

$\begin{array}{ll}\text { amu } & \text { Atomic mass unit } \\ \text { BL } & \text { Blended sludge run in IDMS } \\ \text { CPC } & \text { Chemical Processing Cell } \\ \text { CST } & \text { Crystalline silico titanate } \\ \text { DWPF } & \text { Defense Waste Processing Facility } \\ \text { EDTA } & \text { Ethylenediaminetetraacetic acid } \\ \text { FA } & \text { Formic Acid } \\ \text { FAVC } & \text { Formic Acid Vent Condenser } \\ \text { GC } & \text { Gas Chromatograph/Gas Chromatography } \\ \text { GFPS } & \text { Glass Feed Preparation System 1/240 }{ }^{\text {th }} \text { scale pilot plant } \\ \text { HAN } & \text { Hydroxyl Amine Nitrate } \\ \text { HAN/FA } & \text { HAN/Formic Acid flowsheet } \\ \text { HG } & \text { Mercury test run in IDMS } \\ \text { HM } & \text { IDMS run with HM simulant (H-modified Purex process) } \\ \text { HWVP } & \text { IDMS run for the Hanford Waste Vitrification Plant } \\ \text { IDMS } & \text { Integrated DWPF Melter System } \\ \text { LEL } & \text { Lower explosive limit } \\ \text { LFL } & \text { Lower flammability limit } \\ \text { MWWT } & \text { Mercury Water Wash Tank } \\ \text { NA/LW } & \text { Nitric Acid/Late Wash flowsheet } \\ \text { NCAW } & \text { Neutralized Current Acid Waste } \\ \text { NTA } & \text { Nitrilotriacetic acid } \\ \text { PHA } & \text { Precipitate Hydrolysis Aqueous process } \\ \text { PHA } & \text { IDMS run with PHA addition (HAN/Formic Acid flowsheet) } \\ \text { PNNL } & \text { Pacific Northwest National Lab } \\ \text { PX } & \text { IDMS run with Purex simulant } \\ \text { SB } & \text { Sludge Batch } \\ \text { SEM } & \text { Scanning electron microscopy } \\ \text { SME } & \text { Slurry Mix Evaporator } \\ \text { SRAT } & \text { Sludge Receipt and Adjustment Tank } \\ \text { SRNL } & \text { Savannah River National Laboratory } \\ \text { SRS } & \text { Savannah River Site } \\ \text { SRTC } & \text { Savannah River Technology Center (predecessor to the national lab) } \\ \text { UGa } & \text { University of Georgia (Athens) } \\ \text { WSRC } & \text { Westinghouse Savannah River Company } \\ & \end{array}$




\subsection{INTRODUCTION}

Hydrogen is generated during processing of radioactive waste sludge in the Defense Waste Processing Facility (DWPF) Chemical Processing Cell (CPC). The two main process vessels in the CPC are the Sludge Receipt and Adjustment Tank (SRAT) and the Slurry Mix Evaporator (SME). Hydrogen is generated during both SRAT and SME vessel operations.

The current safety strategy mitigates the hazards associated with hydrogen-air mixtures by diluting the vessel off-gases with a large air purge flow. The vessels are operated at a slight negative pressure. Additional air is drawn into the SRAT and SME through any available opening above the sludge level. Credit is not taken for this additional air flow, however, in the safety basis calculations.

The current qualification strategy for new sludge batch compositions in DWPF is designed to assess the likelihood of significant hydrogen generation. Process simulations using non-radioactive simulants are used to investigate the range of acid additions that avoid the region of excessive hydrogen generation while meeting other processing goals. This defines an acid addition window. A single simulation is performed with a sample of radioactive waste to confirm the suitability of a point inside the acid addition window established by the simulant tests.

The historical, nominal DWPF SRAT and SME air purge flows were 188 and 66 std. $\mathrm{ft}^{3}$ per minute, scfm, respectively. (The DWPF air purges are now taken to be $230 \mathrm{cfm}$ and $70 \mathrm{cfm}$ at $70^{\circ} \mathrm{F}$ and $1 \mathrm{~atm}$, but this doesn't impact the time period reviewed.) The design basis maximum hydrogen flows are 0.65 and 0.23 $\mathrm{lb} / \mathrm{hr}$ in the SRAT and SME respectively. These correspond to 2.0 and $0.72 \mathrm{scfm}$ (basis $1 \mathrm{lb}-\mathrm{mole}=379.5$ std. $\mathrm{ft}^{3}$ at $60^{\circ} \mathrm{F}$ and $\left.1 \mathrm{~atm}\right)$. Hydrogen would be present at about 1.09 volume $\%$ at the design basis hydrogen flow rate in the historical, nominal air purge for both vessels. The hydrogen concentration at the design basis maximum hydrogen flow is approximately one-fourth of the concentration for the lower flammability limit, LFL, of hydrogen in air (used synonymously with lower explosive limit for the purpose of this review). The presence of other gases, such as $\mathrm{N}_{2} \mathrm{O}$, in the system can alter the LFL for hydrogen. Methods for handling this were proposed in SRT-PTD-90-0066, R. A. Jacobs, LEL Control of the IDMS SRAT (U).

The primary source of hydrogen has been identified as the decomposition of formic acid added in the SRAT cycle as a reducing agent. Significantly smaller amounts of formic acid have generally been used to promote the transfer of glass frit-water slurries in the SME cycle as well. The main source of hydrogen is not radiolytic decomposition of water, though radiolysis does contribute some hydrogen. The formic acid decomposition reaction is catalyzed by noble metals, e.g. palladium, rhodium, and ruthenium. The noble metals formed as the final fission products of the ${ }^{235} \mathrm{U}$ decay chain. $\mathrm{Pd}, \mathrm{Rh}$, and $\mathrm{Ru}$ have been identified as critical to catalytic formic acid decomposition.

\subsection{REVIEW OF PAST WORK}

Past on- and off-site work was collected on the catalytic decomposition of formic acid to produce hydrogen. A comprehensive review of work through 2001 follows. The review has been organized into six broad sections. The information within each section is generally similar, e.g. data collected in the Shielded Cells or data collected prior to DWPF start-up. The first section includes:

- General off-site studies on formic acid decomposition including Pacific Northwest National Laboratory (PNNL) work 
The remaining five sections include work performed at or for the former Savannah River Technology Center (SRTC):

- Early SRTC bench-scale studies with simulants (C.W. Hsu et al.)

- The specific University of Georgia study for SRTC (King et al.)

- Integrated DWPF Melter System (IDMS) pilot plant hydrogen findings

- Shielded Cells experiments

- Various Sludge Batch (Macrobatch) studies with simulants

Please note the following:

- This organization is not chronological, since some of the above studies occurred in parallel.

- Discussion within each section, however, is essentially chronological, starting with the oldest work.

- Shielded Cells experiments have been made throughout the period of interest, but were all collected into a single section. The other four sections contain simulant experiments only.

- Parenthetical comments within the review are typically fresh perspectives on the findings presented here for the first time based on the entire body of work.

A summary of findings, contradictions, and open issues follows the review and serves as an introduction to the recommendations for future work.

\subsection{Off-site Studies on General Systems}

\subsubsection{Bond, G. C. [1962]}

G.C. Bond summarized the following findings on formic acid decomposition (pure formic acid) caused by various metals, i.e. not limited to noble metals:

1) Hydrogen and carbon dioxide are the primary products, but not the only products.

2) Water and carbon monoxide are also found in the decomposition products in amounts varying from traces to substantial fractions; the observed quantities have fallen on either side of the equilibrium yield of roughly $6 \% \mathrm{CO}, 94 \% \mathrm{CO}_{2}$. The two species can work toward equilibrium from either side using the water gas shift reaction:

$$
\mathrm{H}_{2}+\mathrm{CO}_{2} \leftrightarrow \mathrm{H}_{2} \mathrm{O}+\mathrm{CO}
$$

3) Chemisorption of formic acid on metals is associated with the loss of the acidic hydrogen atom.

4) The HCOO species may or may not exist in an ionized state on the surface.

5) Tests with deuterated formic acid indicate that the decomposition is not intramolecular. (Tests produced molecular hydrogen species that could not be formed by intramolecular reactions of the starting molecules, e.g. if starting with HCOOD, there was production of $\mathrm{D}_{2}$. $\mathrm{D}$ is an abbreviation for deuterium, ${ }^{2} \mathrm{H}$.)

6) The products of the decomposition inhibit the rate of decomposition for some of the metals, although copper and silver are potential exceptions, and there may be others. For nickel metal the sequence is reported as $\mathrm{CO}_{2}>\mathrm{H}_{2} \mathrm{O}>\mathrm{H}_{2}>\mathrm{CO}$. (Note that in a metal catalyzed gas phase 
reaction, any competition for adsorption sites can inhibit the rate of reaction. The preferred adsorption of the products over formic acid may be what has been observed.)

7) A ranking of relative activities of various metals gives:

$$
\mathrm{Ru}>\mathrm{Pd}>\mathrm{Rh}>\mathrm{Ni}>\mathrm{Ag}>\mathrm{Fe}
$$

Platinum and iridium were more reactive than any of the above metals. (These are absent from SRS sludge, and there was no corresponding data for copper.)

8) The rate limiting step in the decomposition kinetics has not been unambiguously determined (or perhaps varies from metal to metal). Two are given here. One mechanism has the HCOO radical species, adsorbed on one surface site, spread to cover two additional adjacent sites forming a doubly adsorbed $\mathrm{O}-\mathrm{C}-\mathrm{O}$ and an adsorbed hydrogen atom. A competing mechanism has a formic acid molecule adsorb onto two sites producing adsorbed neutral HCOO and adsorbed hydrogen as the rate limiting step.

SRS observations related to this data would note that there was no nitrite ion, so there was no possibility of forming noble metal nitrite complexes. The two mechanisms in 8) both detach a hydrogen atom and are consistent with the observation in 5) that the reaction is not intramolecular. The implication is that both formate (HCOO as either radical or ion) as well as molecular formic acid can be decomposed to hydrogen and carbon dioxide through an electron transfer reaction.

\subsubsection{Müller and Loerpabel [1929]}

Müller and Loerpabel studied the decomposition of aqueous solutions of formic acid in the presence of the platinum group metals at $100^{\circ} \mathrm{C}$. Among their findings:

1) Only carbon dioxide and hydrogen were formed as decomposition products (not what was reported in Bond, 2.1.1).

2) Activity ranked as: $\mathrm{Pd}>\mathrm{Ir}>\mathrm{Rh}>\mathrm{Pt}>\mathrm{Os}>\mathrm{Ru}$ (not the same order as Bond).

3) Some metals, e.g. Os and $\mathrm{Ru}$ had an induction period, which was the time for formic acid to reduce the metal to a catalytically active form.

4) Shorter induction periods correlated to higher maximum hydrogen generation rates.

5) Metals that activated quickly and had high maximum hydrogen generation rates also tended to deactivate more quickly. (The mechanism of deactivation is not well understood.)

In Müller [1924] it was noted that the coagulation of colloidal ruthenium was not nearly as rapid as for platinum and osmium. In Müller [1925] it was noted that metallic powders of $\mathrm{Ru}$ and $\mathrm{Pd}$, as well as metals formed by reduction of metal hydroxides were less reactive than metals formed from metal salts added to formic acid/sodium formate solutions. (Some anions may promote an equilibrium between the cation and the reduced form.) The abstracts from these two earlier papers by Müller were given in SRLPTD-90-0082.

SRS observations indicate a role for $\mathrm{Ru}$ that has been hard to quantify. This may relate to the induction and coagulation period issues. Simulant tests start with $\mathrm{Rh}$ and $\mathrm{Pd}$ nitrates and $\mathrm{RuCl}_{3}$ as trim chemicals. The nitrates are in solution, but presumably convert to metal hydroxides in the basic sludge simulant. 
Nevertheless, it is not likely that any soluble $\mathrm{Pd}$ or $\mathrm{Rh}$ salt would behave differently. The catalytic activities of the noble metals used in process simulations with simulants are probably conservative, i.e. likely to produce as much or more hydrogen compared to those in real waste.

\subsubsection{Ruthven and Upadhye [1971]}

Ruthven and Upadhye also studied aqueous phase formic acid decomposition for palladium. Among their findings:

1) Only carbon dioxide and hydrogen were formed (in agreement with Müller and Loerpabel, 2.1.2).

2) Heat of adsorption (probably of $\mathrm{HCOOH}$ ) was comparable to vapor phase studies, suggesting a similar surface intermediate species may be formed. (This could imply a similar reaction mechanism.)

3) Palladium deactivated continuously during the course of the decomposition. (This seems to imply zero induction time.)

4) They attributed deactivation to hydrogen adsorption by palladium. (Palladium is well known for its ability to store hydrogen in the spaces between palladium atoms in the solid phase.)

5) The kinetics were approximately one-half order in formic acid concentration. (Note: any solid catalyzed system that behaves between zero and first order suggests that one of the LangmuirHinshelwood kinetic models for reactions occurring at surface sites might be more suitable.)

SRS has not definitively linked catalytic hydrogen generation to palladium, section 2.3.

\subsubsection{Smith and Ortman [1984]}

Smith and Ortman studied the effect of mercury on the reaction between hydrogen and palladium. Palladium and hydrogen undergo a rapid, reversible reaction at room temperature to form a palladium hydride. Mercury at 0.017 grams/gram palladium poisoned this reaction. This may or may not relate to the activity, or lack of activity, of palladium in site waste and site waste simulants.

\subsubsection{Hill and Winterbottom [1988]}

Hill and Winterbottom studied palladium catalyzed decomposition of aqueous phase formic acid in the presence of sodium formate.

1) The apparent reaction rate dependence on total formate concentration varied between 0.33 and 1.07 order, depending on which species was predominantly present.

2) Two reaction mechanisms were proposed, one for high formate ion concentration and one for low formate ion concentration.

3) The optimum $\mathrm{pH}$ range was 3.8-6.5.

4) Hydrogen evolution could not be sustained over time if the palladium concentration fell below a threshold value.

5) Pretreating the catalyst surface with formaldehyde caused catalyst poisoning.

6) Addition of methyl formate led to a reduced hydrogen yield. 
7) Palladium hydride was cited as a possible poison.

Note that the varying reaction order is typical of heterogeneous catalysis that can be modeled by Langmuir-Hinshelwood type rate expressions. The optimum $\mathrm{pH}$ range is not in contradiction with data from SRS process simulations.

\subsubsection{Wiemers [1988]}

The actual discovery that hydrogen was being produced during the formating of simulated waste sludges was made by Karen Wiemers at Pacific Northwest Laboratory, PNL-SA-15965, [1988]. Hanford "NCAW" (neutralized current acid waste) sludge simulant was doped with rhodium and ruthenium, but not with palladium. The simulant was very rich in zirconium and contained more sodium than a Purex simulant. Test batches contained two liters of sludge. The SRAT was purged at about 100 standard cubic centimeters per minute, $\mathrm{sccm}$, (or $22 \%$ of a $188 \mathrm{scfm}$ purge). Hydrogen peaked at $1.6 \%(\sim 0.3 \%$ if diluted to $22 \%$ ). Rh was at about $0.15 \mathrm{wt}$. \% and Ru was at about $0.5 \mathrm{wt}$. \% on a dry solids basis.

This study was closer to DWPF processing conditions than the other studies reviewed so far. The Rh and $\mathrm{Ru}$ concentrations were higher than have been seen in the first three sludge batches in DWPF.

\subsubsection{Langowski et al. [1996]}

Langowski et al., PNL-11043, characterized off-gas from Hanford Waste Vitrification Plant (HWVP) feed pretreatment of simulant and of an AZ-102 core sample. Simulant tests were at both $1500 \mathrm{~mL}$ and $80 \mathrm{~mL}$ sludge volumes. Radioactive tests were at up to $80 \mathrm{ml}$ volumes. Formic acid was added at $95^{\circ} \mathrm{C}$, the SRAT was refluxed for four hours, recycle waste was added, and then the SRAT was refluxed for two hours. Their observations and findings included:

1) The core sample had fully dried out before testing and was reslurried with deionized water.

2) Hydrogen generation did not match between simulant and the core sample.

3) Repeatability of tests was $\pm 25 \%$.

4) Increasing the feed carbonate concentration delayed the initiation of hydrogen production.

5) The peak hydrogen production rate increased as the slurry $\mathrm{pH}$ (at the time of hydrogen initiation) fell.

6) In one pair of runs, a $20 \%$ increase in acid added led to $40 \%$ less total hydrogen produced.

7) One simulant test was repeated on the cold bench top and in the hot cell. Total hydrogen produced was $50 \%$ higher in the cold test.

8) In one simulant test, Pd was increased by $22.4 \mathrm{x}, \mathrm{Rh}$ by $9.3 \mathrm{x}$, and Ru by $3.1 \mathrm{x}$, while acid was reduced to 0.75 of the base run. Additional carbonate was added. 2.2x as much hydrogen was produced as in the base run.

9) In a second test, $\mathrm{Pd}$ was increased by $2.2 \mathrm{x}$, $\mathrm{Rh}$ by $2.8 \mathrm{x}$, and $\mathrm{Ru}$ by $3.1 \mathrm{x}$, while acid was reduced to 0.75 of the base run. $1.9 \mathrm{x}$ as much hydrogen was produced as in the base run. 
10) A matching hot sample test produced only $1 / 3$ as much hydrogen. Reducing the acid by $20 \%$ in a second hot sample test also produced about $1 / 3$ as much hydrogen.

11) Hydrogen at small levels was detected in simulant runs with no added noble metals.

12) The hydrogen generation rate in simulant sludge often peaked before the end of formic acid addition, or peaked during reflux, and then decayed.

13) The hydrogen generation rate in radioactive sludge did not peak early.

14) SEM testing on simulant found metallic $\mathrm{Ag}$ with $\mathrm{Ru}, \mathrm{Rh}$, and $\mathrm{Pd}$ mixed in. $\mathrm{Ag}$ was detected by SEM in the core sample, but not the other noble metals.

The observation that hydrogen did not peak as early in radioactive runs as in simulant runs suggests that noble metals in real waste may be harder to activate compared to those in simulants. It is possible that the simulant formed a silver-noble metal alloy with altered catalytic activity. The influence of silver on the SRS noble metals has not been studied. The findings on how noble metal concentration and acid addition enhance hydrogen generation are consistent with SRS experience.

\subsubsection{Wiemers, Langowski, et al. [1996]}

Wiemers, Langowski, et al., PNNL-11029, gave an analysis of data obtained on HWVP off-gas testing in March 1996. These were simulant tests. Test scale was $1.5 \mathrm{~L}$ of sludge slurry at 125 grams waste oxides/liter. Six selected conclusions include:

1) $40 \%$ of the formic acid added was consumed, i.e. the formate portion was destroyed. The acidic proton may have been consumed in other reactions prior to the destruction of the formate portion. This was almost independent of the test variables and conditions.

2) Ammonia was primarily found after significant hydrogen generation, and it was proposed that it was formed from nitrate ion.

3) Significant (second) hydrogen releases were limited to runs where the ratio of $\mathrm{HCOOH}$ to $\mathrm{NO}_{2}{ }^{-}$ reached or exceeded a critical threshold value. Hydrogen generation peaks in runs below this threshold were a factor of ten lower in magnitude. (Unfortunately, there was only raw data to really support this at 0.65 initial moles nitrite. There were only three other tests with significant hydrogen releases in the data set: A second hydrogen release was seen in two runs with 0.2 moles initial nitrite and in one run with 0.4 moles initial nitrite. Total hydrogen produced in these last three runs was not higher than the hydrogen produced in some of the 0.65 mole initial nitrite runs without a second hydrogen release. Peak hydrogen generation rates did correlate to the second hydrogen release.)

4) Hydrogen production increased as formic acid added increased.

5) Peak hydrogen generation rate for various tests ranged from $0-5 \mathrm{lb} . / \mathrm{hr}$ DWPF scale (6000 gallons).

6) An SRTC "empirical formula" for minimum acid requirement was critiqued. PNNL found that manganese solubility was $\sim 80 \%$ at $\mathrm{pH} 4$, the $\mathrm{pH}$ that gave the SRTC target nickel solubility of $30 \%$. The target SRTC manganese solubility of 50\% was observed at $\mathrm{pH}$ 6. At this $\mathrm{pH}$ nickel was barely solubilized. (The only worthwhile point seems to be that SRTC and DWPF should not necessarily expect $50 \% \mathrm{Mn}$ and $30 \% \mathrm{Ni}$ solubility to occur simultaneously.) 
The third conclusion could be related to a series of scoping experiments performed by Lambert and Boley, WSRC-NB-97-240. These suggest that at least some nitrite is necessary to produce the maximum catalytic activity. Too little, and this maximum is not reached, but too much and the hydrogen generation reaction is inhibited. The fifth conclusion indicates hydrogen generation at nearly eight times the DWPF SRAT limit. The role of nitrite ion is probably more complicated than simply needing to eliminate it before seeing hydrogen generation.

\subsubsection{Wet Oxidation of Formic Acid}

There were some papers related to formate decomposition that were not directly related to hydrogen generation, but instead described the catalytic oxidation of wet formic acid, i.e. the formation of carbon dioxide and water from formic acid. There is no hydrogen generation associated with wet oxidation of formic acid. Most of the reactions were being studied at temperatures in excess of $150^{\circ} \mathrm{C}$. Noble metals and copper were catalysts for the oxidation reaction. Some noble metals were active at $80^{\circ} \mathrm{C}$. Silver required fairly high temperatures to be significantly active, typically greater than $200^{\circ} \mathrm{C}$. All organic molecules are susceptible to catalytic wet air oxidation, including the DWPF antifoam chemicals. A paper dealing with palladium focused on ultrathin films on electrodes. This was difficult to relate to SRAT conditions. Four references are given below:

1) Baldauf and Kolb, J. Phys. Chem., 1996, 100, 11375-11381.

2) Shende and Mahajani, Ind. Eng. Chem. Res., 1997, 36, 4809-4814.

3) Cordi and Falconer, Applied Catalysis A: General, 1997, 151, 179-191.

4) Lee and Kim, Catalysis Today, 2000, 63, 249-255.

This topic is relevant to control of the SRAT acid addition to achieve a target iron in glass redox. Some amount of catalytic oxidation of formic acid to carbon dioxide and water could easily occur in the SRAT. The loss of oxygen associated with this reaction would be hard to detect in the laboratory using the GC on samples of the prototypical air purge. Furthermore, the bench-scale experiment is small in size, and it would be considerably easier to keep oxygen levels up in the sludge than in a 7-8000 gallon system. This is due to the nine inch distance from the free surface to the bottom of the kettle. Catalytic wet air oxidation competes with hydrogen generation for formate and formic acid molecules and may also compete for the same catalytic reaction sites. The latter would be more significant, since formate ion holds at a fairly high concentration throughout processing, i.e. pseudo steady state.

\subsection{SRTC Work Reviewed (Next Five Sections)}

The next five sections discuss work done at or for the Savannah River Site in support of the DWPF. Collecting hydrogen generation data was often not the only objective in a majority of the site studies. Many studies were modified flowsheet validations. The main purpose was to establish that a flowsheet modification was acceptable, rather than to understand the mechanisms of hydrogen generation. Consequently, it may appear that these reports sometimes duplicated findings with respect to hydrogen generation, e.g. that more noble metals or more acid led to more hydrogen generation. Most site studies report the hydrogen generation rates of any SRAT or SRAT/SME simulations, but there were few comparisons made to prior work. This was one of the reasons for performing this review, i.e. to bring together the various bits of information obtained in the past into a single document and to summarize the outstanding issues with respect to hydrogen generation.

The reader of these next five sections is cautioned as follows. First, there will be a number of tables that present a basis composition for noble metals, such as the Purex basis or the HM basis. These basis values changed over time. The tables generally show the basis compositions used at the time of the study, i.e. 
the compositions cited in the study. There were two other simulants studied at this time. These were referred to as "Blend" and as "Batch 1". Blend was as simulated nominal blend of Purex and HM wastes, while Batch 1 had a simulated composition corresponding to the first sludge batch planned for the DWPF. Batch 1 became Sludge Batch 1A (SB1A), also known as Macrobatch one. The most recent noble metal composition bases are given in Table 1. These date from the period near the end of the IDMS runs discussed in Section 2.5.

Table 1 - Mercury and Noble Metal Bases for DWPF Sludges

\begin{tabular}{|l|c|c|c|}
\hline Compound & $\begin{array}{c}\text { Blend } \\
\text { Wt. \% }\end{array}$ & $\begin{array}{c}\text { PUREX } \\
\text { Wt. \% }\end{array}$ & $\begin{array}{c}\text { HM } \\
\text { Wt. \% }\end{array}$ \\
\hline $\mathrm{Ag}$ & 0.014 & 0.014 & 0.014 \\
\hline $\mathrm{Pd}$ & 0.045 & 0.026 & 0.079 \\
\hline $\mathrm{Rh}$ & 0.018 & 0.008 & 0.038 \\
\hline $\mathrm{Ru}$ & 0.100 & 0.028 & 0.217 \\
\hline $\mathrm{Hg}$ & 1.588 & 0.102 & 3.263 \\
\hline
\end{tabular}

Second, there has not been a unified approach to presenting the hydrogen generation results within the SRTC work. This will be apparent in reading summaries below. Hydrogen concentration in the off-gas was determined using gas chromatography. Some researchers reported volume \% (the raw data), some reported peak grams hydrogen/liter sludge, some reported peak $\mathrm{lb} . / \mathrm{hr}$ hydrogen at "DWPF scale" (typically 6000 gallons of fresh sludge), and some further scaled their hydrogen generation rate results to the DWPF sludge maximum wt. \% total solids of 19\%. (Data were not found that would indicate that a 19 wt. \% total solids SRAT peak hydrogen generation rate would be (19/16) times that obtained in a run at $16 \mathrm{wt}$. \% total solids.) Recent reports typically give a plot of volume \% hydrogen versus processing time, and most convert these data to equivalent DWPF lbs/hr hydrogen for comparison to the DWPF SRAT limit of 0.65

Third, many experiments were conducted prior to the finalization of the DWPF design bases. SRAT purge rates were primarily at the discretion of the researcher during 1990-1993. Purging was sometimes with nitrogen, with argon, or with air. Most later simulant work attempted to use a scaled air purge prototypical of the design nominal DWPF air purge, $188 \mathrm{scfm}$ in the SRAT.

Fourth, the current SRAT acid calculation algorithm was not in use for the early work. Data that would constitute the critical inputs to the acid calculation (wt. \% solids, pH 7 base equivalents, TIC, Mn, nitrite, and mercury) were generally incomplete. It appears to be impossible to reconstruct the predicted acid stoichiometries by the current algorithm for SRAT tests before 1995 in most cases. The period of intense study from 1990-1993 was particularly affected. There were many SRAT runs in this period, and it would have been beneficial to have put the data on a contemporary basis.

An attempt has been made in this report to recalculate experimental hydrogen generation rates and/or volume \%'s to a standard full-scale system containing 6000 gallons of fresh sludge in a nominal air purge flow by standard cubic feet per minute (rather than $\mathrm{lb} / \mathrm{hr}$, since air was not always used). Original data (lab notebooks) were consulted to a large extent before attempting this, but there is always a chance that this recalculation might introduce some additional error to the data. Generation rates were not adjusted for variations in wt. \% total solids of the sludge. 


\subsection{Simulant Work by C.W. Hsu et al.}

\subsubsection{WSRC-RP-90-664}

WSRC-RP-90-664, by C. W. Hsu describes scoping studies with DWPF sludge slurry simulants containing nominal mercury and worst case noble metals. Three experiments were run. One contained mercury and no noble metals, one contained noble metals and no mercury, and the third had both noble metals and mercury. Formic acid was added to the sludge at $93^{\circ} \mathrm{C}$, and then the system was brought to boiling and refluxed. There was no gas purge, and the system was air-tight. Hydrogen production appears to have been higher in the run with no mercury (there was no hydrogen production in the run without noble metals).

The three earliest available lab notebooks assigned to Hsu were retrieved from Records and examined. The WSRC-RP-90-664 data are earlier than anything recorded there, so this reported data could not be critically reviewed against the raw data. It appears from the apparatus sketch that mercury may have been refluxed with water in this early apparatus. The form of the noble metal trim chemicals added is not given. The sludge basis noble metal composition was:

Table 2 - Noble Metal Basis for 1990 Hsu Scoping Work

\begin{tabular}{|l|l|l|l|}
\hline Element & $\begin{array}{c}\text { Hsu } \\
\text { Scoping }\end{array}$ & Purex Basis & HM Basis \\
\hline $\mathrm{Hg}$ & $1.2 \%$ & $0.0036 \%$ & $1.166 \%$ \\
\hline $\mathrm{Ag}$ & $0.014 \%$ & $0.014 \%$ & $0.014 \%$ \\
\hline $\mathrm{Pd}$ & $0.079 \%$ & $0.026 \%$ & $0.079 \%$ \\
\hline $\mathrm{Rh}$ & $0.038 \%$ & $0.008 \%$ & $0.038 \%$ \\
\hline $\mathrm{Ru}$ & $0.22 \%$ & $0.028 \%$ & $0.217 \%$ \\
\hline
\end{tabular}

The then-current Purex and HM basis concentrations are shown for comparison. One interesting feature is the presence of silver, which was not included in much of the later work by Hsu. "Worst case" concentrations for rhodium, palladium, and mercury were increased in later tests. The justification for this was not found.

\subsubsection{SRL-PTD-90-0082}

Hsu did a literature search on the hydrogen concern in the SRAT. She mentioned that SEM and x-ray analyses indicate the presence of $\mathrm{Pd}-\mathrm{Ag}, \mathrm{Pd}-\mathrm{Hg}, \mathrm{Ag}-\mathrm{Hg}$ (alloys or amalgams), and of pure $\mathrm{Pd}$ in sludge. The source for this information was not referenced.

\subsubsection{WSRC-MS-92-270}

The next series of tests by Hsu was reported in WSRC-MS-92-270, and the supporting original data were found in WSRC-NB-90-182. The apparatus schematic suggests that mercury was still being refluxed along with condensate (discussions with R. E. Eibling, however, suggest that there was a small dimple in the bottom of the condenser which tended to retain some of the stripped mercury). Improvements included a continuous purge gas flow (nitrogen in all this work) and an on-line gas chromatograph.

The scope of this work included testing of individual noble metals, of various levels of acid addition, and of the effects of subsequent additions of sodium hydroxide and/or nitric acid on hydrogen evolution during reflux. The base run used two liters of Purex sludge simulant to which varying amounts of trim noble metals were added, followed by the addition of varying amounts of formic acid at $93^{\circ} \mathrm{C}$ and then by refluxing. All of these tests used high molarity formic acid exclusively for the SRAT cycle. There was 
no nitric acid addition (except in one special test) or PHA addition. This work predates the nitric acid flowsheet. The testing used a $15 \mathrm{wt}$ \% total solids Purex simulant with the following base case composition for trim species (revised Hsu basis column):

Table 3 - Revised Noble Metal Basis for Hsu Simulant Tests

\begin{tabular}{|l|c|c|c|c|}
\hline Element & $\begin{array}{c}\text { Rev. Hsu } \\
\text { Basis }\end{array}$ & Purex Basis & $\begin{array}{c}\text { HM Basis } \\
\text { then }\end{array}$ & $\begin{array}{c}\text { HM Basis } \\
\text { today }\end{array}$ \\
\hline $\mathrm{Hg}$ & none & $0.0036 \%$ & $1.166 \%$ & $3.263 \%$ \\
\hline $\mathrm{Ag}$ & none & $0.014 \%$ & $0.014 \%$ & $0.014 \%$ \\
\hline $\mathrm{Pd}$ & $0.0935 \%$ & $0.026 \%$ & $0.079 \%$ & $0.079 \%$ \\
\hline $\mathrm{Rh}$ & $0.0437 \%$ & $0.008 \%$ & $0.038 \%$ & $0.038 \%$ \\
\hline $\mathrm{Ru}$ & $0.216 \%$ & $0.028 \%$ & $0.217 \%$ & $0.217 \%$ \\
\hline
\end{tabular}

There was 2.46 wt. $\% \mathrm{NaNO}_{2}$ on a dry solids basis in the Purex sludge simulant. Table 4 below summarizes Hsu's tests documented in WSRC-NB-90-182. Maximum hydrogen volume percents were algebraically rescaled to a present-day DWPF purge rate dilution without recourse to a sophisticated dynamic model. These Hsu SRAT tests were conducted between 5/23/91 and 11/15/91.

Table 4 - Summary of WSRC-NB-90-182 SRAT Tests

\begin{tabular}{|c|c|c|c|c|c|c|c|}
\hline $\begin{array}{l}\text { Run } \\
\text { Name }\end{array}$ & \begin{tabular}{|l|} 
Formic \\
Acid, $\mathrm{ml}$ \\
\end{tabular} & Rh-\% & $\mathrm{Ru}-\%$ & $\mathrm{Pd}-\%$ & $\begin{array}{l}\text { Purge, } \\
\text { sccm }\end{array}$ & $\begin{array}{l}\mathrm{Max} \mathrm{H}_{2} \\
\text { vol. \% }\end{array}$ & $\begin{array}{l}\text { DWPF } \\
\text { vol. } \%\end{array}$ \\
\hline 1 & 62 & 0 & 0 & 0 & 50 & $<0.01$ & $<0.01$ \\
\hline 2 & 62 & 0 & 0 & 0 & 50 & $\sim 0.01$ & $\sim 0.01$ \\
\hline 3 & 80 & $0.044 ?$ & 0 & 0 & 100 & 1. & 0.22 \\
\hline 4 & 62 & $0.038 ?$ & $0.22 ?$ & $0.08 ?$ & 100 & 0.03 & 0.01 \\
\hline 5 & 80 & 0 & 0 & $0.096 ?$ & 100 & 0.04 & 0.01 \\
\hline 6 & 84 & 0 & $0.23 ?$ & 0 & 100 & 0.90 & 0.20 \\
\hline NMPX2 & 80 & 0.0437 & 0.216 & 0.0935 & 100 & 1.75 & 0.38 \\
\hline NMPX HC & & & & & $100 ?$ & 1.9 & $0.41 ?$ \\
\hline NMPX3 & 120 & 0.0437 & 0.216 & 0.0935 & 200 & 6.6 & 2.9 \\
\hline NMPX4 & 100 & 0.0437 & 0.216 & 0.0935 & 200 & 2.9 & 1.3 \\
\hline NMPX5 & 121 & 0.0437 & 0.216 & $\begin{array}{l}0.09-0.18 \\
?\end{array}$ & 300 & 5.5 & 3.6 \\
\hline NMPX6 & 120 & 0.0437 & $\begin{array}{l}0.216- \\
0.375 ?\end{array}$ & 0.0935 & 300 & 5.5 & 3.6 \\
\hline NMPX6AC & - & - & - & - & - & - & - \\
\hline NMPX7 & 60 & 0.0437 & 0.216 & 0.0935 & 200 & 0.3 & 0.13 \\
\hline NMPX8 & $\sim 80$ & $0.0437 ?$ & $0.216 ?$ & $0.0935 ?$ & 200 & 0.7 & 0.30 \\
\hline NMPX9 & 100 & 0.0437 & 0.216 & 0.0935 & 200 & 4.2 & 1.8 \\
\hline NMPX10 & 120 & 0.0437 & 0 & 0 & 300 & 5. & 3.3 \\
\hline NMPX11 & 120 & 0 & 0.216 & 0 & $300 ?$ & $\sim 4$. & $2.6 ?$ \\
\hline NMPX12 & 120 & 0 & 0 & 0.0935 & 300 & 0.02 & 0.01 \\
\hline NMPX13 & 120 & 0.0876 & 0 & 0 & 300 & 11. & 7.2 \\
\hline PXNTA1 & $120 ?$ & $0.0437 ?$ & $0.216 ?$ & $0.0935 ?$ & $300 ?$ & 1.5 & $1.0 ?$ \\
\hline
\end{tabular}

Question marks indicate places where the notebook information was not $100 \%$ certain. This was typically an issue with the wt. \% dry solids in the sludge or the wt. \% noble metal content of a trim chemical 
relative to the computation of the wt. $\%$ noble metal in the dry sludge. In two cases there was no readily identifiable record of the purge gas flow. Runs 1, 2, and 4 used an HM sludge simulant. All of the other runs used a Purex sludge simulant. Run 4 had a heel. Run 4 was also the only run to contain silver. There was no mercury added in any of these tests. No additional nitrite ion source was added to the sludge (the Purex sludge appears to have been fairly low in nitrite). Nitrite was associated with ammonium nitrate and nitrated organics at the time. Run 4 and Run NMPX HC had a PHA addition phase. The other runs apparently did not have a PHA step (100\% of the acid used was $~ 90 \%$ formic acid; there was no nitric acid flowsheet at this time). NMPX6AC took the NMPX6 SRAT contents and subjected them to a series of small nitric acid additions. NMPX5 had some sodium hydroxide additions. PXNTA1 had 5 grams of NTA added to it.

One major issue in relating this data to present day processing was the use of the formic acid flowsheet. Another issue was the potential effect of an inert purge gas on the results. The purge ranged from 100$300 \mathrm{sccm}$ nitrogen in the runs with noble metals. A nominal DWPF SRAT purge would be about 460 sccm air. Unambiguous conclusions from this data include:

1) Rhodium in the absence of the other two noble metals activated quickly and was almost certainly responsible for the peak generation rate seen in tests with blended noble metals. Rhodium also began to lose activity shortly after the peak rate, while the $\mathrm{pH}$ of the sludge was still quite acidic, i.e. there was still plenty of formic acid available. Hydrogen concentration peaked near 4-5\% in a $300 \mathrm{sccm}$ purge flow $(\sim 2.7-3.3 \%$ in a nominal purge). Sludge $\mathrm{pH}$ ranged from just below 4 to just above 4 during the test. When rhodium was doubled (no other noble metals present), the peak generation rate was claimed to have increased by $\sim 2.5$ times, and the peak hydrogen concentration was near $11 \%$ in a $300 \mathrm{sccm}$ purge flow.

2) Ruthenium alone activated more slowly than rhodium, but ultimately appeared to produce more total hydrogen. The ruthenium-derived hydrogen generation rate peaked at roughly one-third the generation rate achieved by rhodium. Hydrogen concentration peaked near $1 \%$ in a $300 \mathrm{sccm}$ purge flow. The sludge $\mathrm{pH}$ rose from just below 4 to above 6 during the refluxing period, i.e. significant formic acid destruction occurred.

3) Palladium alone was a weak catalyst. Hydrogen concentration peaked at about $0.02 \%$. Palladium activated quickly and did not appear to be deactivating. No mercury was present, so any potential mercury poisoning or enhancement was suppressed. Sludge $\mathrm{pH}$ remained constant at 4 during refluxing. (Based on outside work with simple test solutions, it is quite likely that palladium metal in the SRAT forms in the active state before there is much formic acid to convert to hydrogen, and is essentially deactivated by one or more of the proposed mechanisms before the rhodium peak generation.)

4) Increasing the amount of formic acid added led to higher hydrogen generation peak rates, higher peak hydrogen concentrations, higher total hydrogen generation when generation rate was integrated over time, and higher final sludge $\mathrm{pH}$ (increased loss of formic acid).

The finding that adding more total acid can produce a higher final SRAT product $\mathrm{pH}$ has been observed in other simulant tests. This may be seen as somewhat counter-intuitive. It appears that formic acid promotes its own destruction.

\subsubsection{Commentary on 2.3.1 and 2.3.2 and 2.3.3}

One issue with some of the data interpretation was the method for calculation of peak hydrogen generation rate (true for all such calculations up to the present, not just those reviewed in this report). Hsu's experimental apparatus contained over 2000 cubic centimeters of dead volume between the sludge 
and the gas chromatograph. With a $300 \mathrm{sccm}$ purge, there was both a significant dead time and a damping effect on the measured hydrogen concentration and flow relative to the evolved hydrogen rate.

Actual generation rates in the bench-scale SRAT must be higher than those being calculated from raw GC data based on qualitative dynamical considerations. The off-gas equipment should not be treated as in plug flow. Consequently, hydrogen being evolved during the period of increasing generation is partially diverted into diluting the other gases held within the system. The more rapid the rate of rise in generation rate, the greater the dilution requirement.

The present-day use of the helium internal standard mitigates some of the process dynamic effects such as fluctuations in boil-up rate. Changes in the boil-up rate affect the dynamics between the SRAT and the condenser. Spikes in boil-up rate tend to purge accumulated gases from the apparatus. Furthermore, the dynamic responses of a steady flow, e.g. He, and a changing flow, e.g. $\mathrm{H}_{2}$, to such upsets are not identical. The internal standard does allow for a reasonable estimation of total hydrogen mass produced by simultaneously providing a fairly good indication of exit flow rate and composition. Simulations with intermittent boil-up, e.g. IDMS runs that suffered from numerous interlocks that shut down the steam flow, present major challenges to the calculation of maximum hydrogen generation rate.

It is necessary to understand the impact of these dynamic factors on the observable quantities and to correct for them before attempting to calculate reaction order or an accurate hydrogen generation rate within the sludge mass. This understanding is also necessary before comparing data between different scales or in different equipment configurations.

In Hsu's study on the effect of total acid, there were lower purge flows in low acid runs and higher purge flows in high acid runs. Noble metals were at the nominal levels in Table 5 above. Only one of the four acid levels had truly replicate trials. It is doubtful that the order of the reaction with respect to formic acid mass acid could be more than roughly approximated from the data.

Hsu reports data for three concentrations of rhodium (no Ru or Pd) at constant formic acid in her report, but only two concentrations could be found in the lab notebook where the related data were recorded. That makes it impossible to speak to issues that were not discussed in the report such as variations in purge gas flow, etc. Even if that extra data were available, the conclusion that the reaction was 1.4 order in rhodium concentration must only be considered a preliminary estimate.

It is likely that the reaction is linear, or first order, in the total rhodium surface area (under the assumption that the reaction is heterogeneous). The rate constant would include the dependence on rhodium, and rate constants are usually present as linear terms. The surface area is potentially changing over time, but even the initial surface area, following reduction to the metal, is probably not a linear function of concentration.

Hsu also reported on the addition of nitriloacetic acid (NTA), the addition of incremental amounts of nitric acid, and the addition of incremental amounts of caustic to the sludge under reflux. NTA was added at $1.6 \mathrm{wt}$. \% on a dry sludge basis. It lengthened the catalyst induction period and reduced the peak hydrogen generation rate. In a certain sense it made rhodium behave more like ruthenium, which has a longer induction period and a reduced peak generation rate relative to rhodium. The amount of NTA added was not trivial.

In two other tests, small additions of nitric acid to the refluxing sludge caused bursts of increased hydrogen generation (seven additions made). Much of the formic acid added had already gone to sodium formate (presumably ionized), and most of the rest was molecular formic acid. The equilibrium shift would be to higher formic acid and lower formate ion concentrations. While this might indicate that it is 
formic acid rather than formate ion that is decomposing, it could just as easily indicate a dependence of noble metal floccing on $\mathrm{pH}$ or a dependence of generation rate on solution redox potential (see WSRCMS-90-363). The onset of reflux could be expected to be similar to a small addition of acid, since the MWWT contains nitrate and formate at low $\mathrm{pH}$. Bursts in the hydrogen generation rate do not typically accompany the onset of reflux in recent tests.

Small additions of sodium hydroxide initially led to a reduction in hydrogen generation rate. This was the reverse of the above observation for small acid additions. Caustic additions had little impact once sludge $\mathrm{pH}$ neared 7. Hydrogen generation continued above $\mathrm{pH}$ 7. Hydrogen generation was still observed at $\mathrm{pH}$ 8 .

No silver was added in any of the above work in this report. Data suggest that silver-noble metal alloys may exist in the sludge, and outside work indicates that the silver alloys are less active than the pure metals. Sodium nitrite was maintained at a fairly low level in the Purex sludge simulant, and it was not spiked upwards. PNNL work by K.D. Wiemers suggested that initial nitrite may effect the induction times of the noble metals.

In the following year, it became standard practice for Hsu to add sodium nitrite to the simulant. No mercury was added to the simulant in the above tests, perhaps because Hsu's first study showed mercury was an inhibiting factor and that its absence would be conservative (unfortunately, some later work indicated that mercury could enhance the hydrogen generation rate).

\subsubsection{WSRC-RP-92-1194}

Subsequent bench-scale work by Hsu et al. was more flowsheet specific than the above work. In WSRCRP-92-1194, results were reported on the impact of switching from the HAN/FA (hydroxyl ammonium nitrate/formic acid) precipitate hydrolysis flowsheet to the NA/LW (Nitric Acid/Late Wash) flowsheet. Maximum hydrogen generation rates (probably PXNA58 in Table 6 below) were reported as one-sixth the recommended design basis hydrogen generation rate of $0.024 \mathrm{lb} / \mathrm{hr}$.

There appeared to be a potential error in the documentation. $1.5 \mathrm{lbs} / \mathrm{hr}$ hydrogen at DWPF scale was the recommended design basis peak for the HAN flowsheet, based on IDMS worst case testing. $0.65 \mathrm{lbs} / \mathrm{hr}$ was the corresponding basis for NA/LW. The numbers in this report differed by about 60x, suggesting units given in the report perhaps should have been $\mathrm{lbs} / \mathrm{min}$ instead of $\mathrm{lbs} / \mathrm{hr}$. The scaling factor is roughly 10,000 from bench-scale to DWPF-scale.

This test succeeded as a sanity check for the proposed new flowsheet. It added little new information to the understanding of hydrogen generation. This was the first of the Hsu studies in which hydrogen generation shifted from during acid addition (which was now nitric acid instead of formic acid) to during PHA addition, i.e. a coupled process flowsheet.

\subsubsection{WSRC-RP-92-1213}

In WSRC-RP-92-1213 Hsu studied various aspects of hydrogen generation during coupled operation with the NA/LW flowsheet. The raw data were generally found in WSRC-NB-91-205, but some of the data may have been recorded elsewhere (there is a gap between 12/91 and 5/92, and test numbers jump from PXNA3 to PXNA14, while Hsu tended to use consecutive numbering elsewhere). PXNA appears to be shorthand for Purex-Nitric Acid. Major findings included:

1) The induction period appeared to be longer than in the formic acid simulations.

2) The peak hydrogen generation rate and concentration were lower. 
3) The presence of mercury increased the hydrogen generation rate significantly (seven-fold reported, and unquestionably a significant effect).

4) Generation rates from an irradiated slurry were lower than for an unirradiated slurry (one-third reported, but, again, clearly a significant drop).

5) Slower PHA addition, coupled with slower evaporation rate, reduced the peak hydrogen generation rate (by $2.5 \mathrm{x}$, and here, surely, the reduced boiling rate impacted the calculated peak hydrogen generation rate by changing the background dynamics).

The tests detailed in WSRC-NB-91-205 are summarized in Table 5. Tests used the NA/LW flowsheet. All runs were with Purex sludge. This was probably an IDMS Purex sludge. In one place the Purex sludge was referred to as Purex II: "PXNA14 was 2400g Purex II at $12.6 \mathrm{wt}$ \% total solids". Each PXNA run was accompanied by a PXPHA run with a matching number. The second half of the SRAT cycle, covering PHA addition, was coded with PXPHA numbers instead of the original PXNA. The PXPHA code for the second phase of the SRAT tests is ignored in the tabular listing below.

Raw data for mercury content suggest a lack of precise knowledge for this parameter. The notebook reports that damp/moist $\mathrm{Hg}\left(\mathrm{NO}_{3}\right)_{2}$ was used to trim the mercury to the desired concentration. The mass is given for each run. The tabulated numbers for $\mathrm{Hg}$ wt. $\%$ in the dry sludge, Table 5, assume $15 \mathrm{wt} \%$ total solids Purex sludge, with approximately the expected concentration of mercury based on an identical mass of $\mathrm{Hg}\left(\mathrm{NO}_{3}\right)_{2} \cdot \mathrm{H}_{2} \mathrm{O}$ and no additional moisture (upper bound in the sense of mercury mass, though not necessarily with respect to the sludge solids).

The three noble metals, $\mathrm{Pd}, \mathrm{Rh}$, and $\mathrm{Ru}$, were held at fixed concentrations throughout. No information on their relative importance could be obtained. The raw data do bear on the issues of mercury and nitrite ion effects on hydrogen generation. The complicating factor was the PHA characterization and addition rate relative to the peak hydrogen generation rate. 
Table 5 - Summary of WSRC-NB-91-205 SRAT Tests

\begin{tabular}{|l|c|l|c|c|c|c|c|c|c|}
\hline $\begin{array}{l}\text { Run } \\
\text { Name }\end{array}$ & $\begin{array}{c}\text { Nitric } \\
\text { Acid, } \\
\text { ml }\end{array}$ & Rh-\% & Ru-\% & Pd-\% & Hg-\% & $\begin{array}{c}\text { NaNO }_{2} \\
\text { grams }\end{array}$ & $\begin{array}{c}\text { PHA, } \\
\text { ml }\end{array}$ & $\begin{array}{c}\text { Max } \mathrm{H}_{2} \\
\text { vol. \% } \\
\text { lab }\end{array}$ & $\begin{array}{c}\mathrm{Max}_{2} \\
\text { vol. \% } \\
\text { DWPF }\end{array}$ \\
\hline PXNA2 & 140 & 0.0437 & 0.216 & 0.0935 & 0 & 0 & 3000 & 0.05 & 0.01 \\
\hline PXNA3 & 150 & 0.0437 & 0.216 & 0.0935 & $1.17 ?$ & 0 & $3100 ?$ & 0.06 & 0.01 \\
\hline PXNA14 & 95 & 0.0437 & 0.216 & 0.0935 & 0 & 9.6 & 4000 & 0.90 & 0.20 \\
\hline PXNA15 & 62 & 0.0437 & 0.216 & 0.0935 & 0 & 9.6 & 4000 & 0.35 & 0.07 \\
\hline PXNA16 & 95 & 0.0437 & 0.216 & 0.0935 & 0 & 9.6 & 4000 & 0.04 & 0.01 \\
\hline PXNA18 & 40 & 0.0437 & 0.216 & 0.0935 & 0 & 9.6 & 4000 & 0.15 & 0.03 \\
\hline PXNA19 & 61 & 0.0437 & 0.216 & 0.0935 & 3.53 & 9.6 & 4000 & 2 & 0.41 \\
\hline PXNA20 & 61 & 0.0437 & 0.216 & 0.0935 & 3.53 & 9.6 & 4000 & 1 & 0.20 \\
\hline PXNA21 & 62 & $?$ & $?$ & $?$ & $?$ & 9.6 & 4000 & 0.02 & 0.01 \\
\hline PXNA22 & 62 & 0.0437 & 0.216 & 0.0935 & 3.53 & 9.6 & 4000 & 0.80 & 0.16 \\
\hline PXNA23 & 130 & $?$ & $?$ & $?$ & $?$ & 9.6 & - & - & - \\
\hline PXNA24 & 55 & 0.0437 & 0.216 & 0.0935 & 3.53 & 9.6 & 4000 & 3.60 & 0.74 \\
\hline PXNA25 & 92 & 0.0437 & 0.216 & 0.0935 & 3.53 & 9.6 & 4000 & 1.90 & 0.39 \\
\hline PXNA26 & 31 & 0.0437 & 0.216 & 0.0935 & 3.53 & 4.8 & 2000 & 0.85 & 0.35 \\
\hline PXNA27 & 46 & 0.0437 & 0.216 & 0.0935 & 3.53 & 4.8 & 2000 & 1.2 & 0.61 \\
\hline PXNA28 & 54.7 & 0.0437 & 0.216 & 0.0935 & 3.53 & 4.8 & 1600 & 0.7 & 0.29 \\
\hline PXFA29 & 19.76 & 0.0437 & 0.216 & 0.0935 & 3.53 & 4.8 & 0 & 1.3 & 0.53 \\
\hline PXNA30 & 73.6 & 0.0437 & 0.216 & 0.0935 & 3.53 & 4.8 & $?$ & $?$ & $?$ \\
\hline
\end{tabular}

PXFA29 used formic acid rather than nitric acid. PXNA2 \& 3 used 7.5M nitric acid. Generally, neither the nitric acid molarity nor the sludge wt. \% total solids were reported. Maximum hydrogen occurred during the PHA addition/reflux phase in all runs. The first two runs were $2260 \mathrm{~g}$ sludge, the next 11 were $2400 \mathrm{~g}$ sludge, and the last five were $1200 \mathrm{~g}$ sludge (separated by bold lines in Table 5). No data were found for nitrite concentration in this notebook. No acid calculations were given in the modern sense of the word, i.e. as a function of basicity, carbonate, manganese, nitrite, and mercury.

PHA addition nominally averaged $5 \mathrm{ml} / \mathrm{min}( \pm 20 \%)$ for the two liter runs, but it varied considerably from run to run. The notebook documents quite a number of process interruptions during PHA addition. The PHA addition rate appeared to be nominally about half as fast in the one liter runs, i.e. was properly scaled down. In 2-L PXNA20, the addition rate was intentionally reduced to $1 \mathrm{~mL} / \mathrm{min}$. In PXNA21 the PHA was doped with formic acid (31g at $90 \mathrm{wt} . \%$ ) to raise the acid molarity to $0.29 \mathrm{M}$ (but the noble metal information was not located). The amount of formic acid needed in precipitate hydrolysis was under study at this time, and it was increasing. All purges during PHA addition/reflux were $100 \mathrm{sccm}$ of nitrogen. This was true for all of the runs, even the last five runs with only half as much sludge. The implication would be that the last five (PXNA26-30) hydrogen concentrations should be doubled for comparison with the earlier concentrations.

PXNA19 and PXNA22 seem very similar, but there is a large difference in peak hydrogen volume percent. PXNA20 added PHA at about one-fifth the rate of the other two. This produced a significant reduction in peak hydrogen compared to PXNA19, but was of no consequence compared to PXNA22.

PXNA15 compares to both PXNA19 and PXNA22. PXNA15, however, has no mercury. Peak hydrogen concentration was much less in the run without mercury. This was opposite to previous trends for the effect of mercury on hydrogen generation. PXNA15 had a broad hydrogen evolution profile with two 
peaks. The second peak was higher than the first. PXNA19 and 22 had broad hydrogen evolution profiles with a single maximum fairly early on.

PXNA2 vs. PXNA3, conversely, seemed to show that mercury was a weak factor or non-factor in peak hydrogen concentration. Further examination showed that the hydrogen evolution profiles for PXNA2 and PXNA3 were nearly identical over the entire 35 hour period documented, not just at the peak.

A first pass assessment of Table 5 with respect to the effect of nitrite ion would support the claim that increased initial nitrite ion concentration promotes increased peak hydrogen concentration. Note, however, that the runs without increased nitrite ion also generally had less mercury.

Caution to the reader: The reevaluation of past data can be complicated by not knowing the thoughts of the researcher at the time of the tests, or what information was readily available elsewhere at the time, but was not recorded, or by not knowing that a certain test or result was "suspect" for some reason that might not have been recorded in a notebook (accidentally forgot to add a noble metal, GC went out of calibration, etc.).

There is nothing either in the lab notebook or Hsu's reports and manuscripts to indicate that there were any test runs numbered PXNA4-PXNA13 recorded elsewhere. Five months, however, passed between PXNA3 and PXNA14. There were data for a PHA addition to a run numbered 17, but there were no data for a prior acid addition, type of sludge, or level of noble metals. There were data for acid addition for PXNA23, but no data for the PHA addition, i.e. no hydrogen data. The notebook entries ended during PXNA30, and it is not clear if that run was completed. The next notebook (chronologically) located for Hsu did not contain a continuation of PXNA30. It started with PXNA49.

The third Hsu notebook, WSRC-NB-92-99, had several further runs with the nitric acid flowsheet. The purge was switched to air from nitrogen. The runs with hydrogen were being purged at $100 \mathrm{sccm}$ at the time of maximum hydrogen generation. Runs were nominally at $\mathrm{HM}$ levels of $\mathrm{Rh}, \mathrm{Ru}, \mathrm{Pd}$, and $\mathrm{Hg}$. There generally was no silver present.

Table 6 - Summary of WSRC-NB-92-99 SRAT Tests

\begin{tabular}{|l|c|l|l|l|l|l|l|c|c|}
\hline $\begin{array}{l}\text { Run } \\
\text { Name }\end{array}$ & $\begin{array}{c}\text { Nitric } \\
\text { Acid, } \mathrm{ml}\end{array}$ & $\mathrm{Rh}$-\% & $\mathrm{Ru}-\%$ & $\mathrm{Pd}-\%$ & $\mathrm{Hg}-\%$ & $\begin{array}{c}\mathrm{NaNO}_{2} \\
\text { grams }\end{array}$ & PHA, ml & $\begin{array}{c}\text { Max } \mathrm{H}_{2} \\
\text { vol. \% } \\
\text { lab }\end{array}$ & $\begin{array}{c}\text { Max } \mathrm{H}_{2} \\
\text { vol. \% } \\
\text { DWPF }\end{array}$ \\
\hline PXNA49 & 109 & 0 & 0 & 0 & 3.53 & 57.6 & 4000 & 0.0 & 0.0 \\
\hline PXNA50 & 109 & 0 & 0 & 0 & 3.53 & 57.6 & 4000 & 0.0 & 0.0 \\
\hline PXNA51 & 163.4 & 0.045 & 0.22 & 0.10 & 3.53 & 63.4 & 3450 & 0.6 & 0.13 \\
\hline PXNA52 & 34.75 & 0.047 & 0.22 & 0.093 & 3.53 & 15.85 & 1780 & 0.11 & 0.05 \\
\hline PXNA53 & 36.13 & 0.049 & 0.242 & 0.105 & 3.53 & 4.8 & 2000 & 0.5 & 0.21 \\
\hline PXNA54 & 36.13 & 0.049 & 0.242 & 0.105 & 3.53 & 4.8 & 2000 & 1.2 & 0.50 \\
\hline PXNA55 & 37.75 & 0.049 & 0.242 & 0.105 & 3.53 & 4.8 & 2110 & 1.5 & 0.63 \\
\hline PXNA56 & 37.75 & 0.049 & 0.242 & 0.105 & 3.53 & 4.8 & 2110 & 0.5 & 0.21 \\
\hline PXNA57 & 53.14 & $?$ & $?$ & $?$ & $?$ & 23.5 & 2340 & 0.05 & 0.02 \\
\hline PXNA58 & 62.28 & $?$ & $?$ & $?$ & $?$ & $?$ & 1800 & 0.02 & 0.01 \\
\hline 56 SME & $3.52 \mathrm{~g}^{*}$ & - & - & - & - & - & - & No data & No data \\
\hline 58 SME & $3.32 \mathrm{~g}^{*}$ & - & - & - & - & - & - & 0.18 & $?$ \\
\hline
\end{tabular}

* The SME grams acid are for $90 \mathrm{wt}$ \% formic acid added with the frit, not nitric acid. 
The DWPF hydrogen volume percent was scaled by the volume of the starting sludge and lab purge rate compared to a 6000 gallon sludge charge and a nominal purge, $188 \mathrm{scfm}$. PXNA49-51 were two liter runs with Purex sludge simulant. PXNA51 had added silver. This was the only run with any silver. PXNA52 and PXNA57 used S-area blend sludge simulant. They were spiked differently for nitrite than the Purex runs. PXNA52 used 1321 grams, while PXNA57 used 1200 grams. PXNA53, 54, 55, 56, and 58 used $1200 \mathrm{~g}$ of Purex sludge. PXNA58 further claimed to be PX7 sludge (the last IDMS run was PX7, section 2.5). PXNA51 suffered from excessive foaming that was traced to out-of-date antifoam. PXNA54 used PHEF PHA trimmed to 0.29M. PXNA55 PHA was trimmed to 0.30M. PXNA57 PHA was trimmed to $0.31 \mathrm{M}$.

\subsubsection{WSRC-RP-92-1236}

WSRC-RP-92-1236 bridges between the above work and IDMS runs. Bench-scale and IDMS results were discussed. The bench-scale results were from the report above, WSRC-RP-92-1213. IDMS peak hydrogen generation rates from IDMS runs PX4 and PX5 were 0.21 and $0.67 \mathrm{lb} / \mathrm{hr}$ (DWPF scale). These were reported as $86 \%$ and $55 \%$ decreases in the peak hydrogen generation rate compared to the Formic Acid/HAN flowsheet design basis. (IDMS runs are discussed separately in this report in section 2.5.)

\subsubsection{WSRC-TR-94-0513}

This report covers hydrogen evolution for the LW/NA flowsheet. At this time the DWPF design basis for peak hydrogen generation in the SRAT was being cut from $1.5 \mathrm{lb} / \mathrm{hr}$ to $0.65 \mathrm{lb} / \mathrm{hr}$ based on the results of IDMS run PX5. Two tests were run with IDMS Purex sludge simulant. One test used 0.3M acidity PHA at $1070 \mathrm{ppm}$ copper prepared in the lab. This PHA was irradiated to 200MRad and processed through a simulated Late Wash Cycle. The second test used 0.3M acidity PHA containing $950 \mathrm{ppm}$ copper prepared in PHEF (run \#70). The study was concerned with the question of whether or not interlocks during IDMS PX5 operation had led to an understated peak hydrogen generation rate.

Bench-scale process simulations were made with IDMS PX5 extremes (21\% excess nitric acid, 30\% excess PHA, rapid PHA addition at $0.3 \mathrm{M}$ ). HM levels of mercury were probably present. Noble metals were present at $0.044 \% \mathrm{Rh}, 0.095 \% \mathrm{Pd}$, and $0.217 \% \mathrm{Ru}$. Nitrite was adjusted to $0.06 \mathrm{M}$ in the Purex sludge. The higher hydrogen generation rates were seen in the test with PHEF PHA. SRAT hydrogen peaked at $0.55 \mathrm{lb} / \mathrm{hr}$ DWPF scale during PHA reflux (1.37 vol. \% in a $100 \mathrm{sccm}$ purge that was running $130 \mathrm{sccm}$ at the condenser outlet at the time). In the test with irradiated PHA, SRAT hydrogen peaked at $0.18 \mathrm{lb} / \mathrm{hr}$ which was below both the SRAT and SME hydrogen design bases.

\subsubsection{Commentary on 2.3.4, 2.3.5, 2.3.6 and 2.3.7}

As the simulant work became more flowsheet specific, the data that were generated also became less general than the earlier data that Hsu obtained. Trends found in the earlier work were generally substantiated, e.g. more acid leads to more hydrogen, higher noble metal concentrations leads to more hydrogen, etc. One unusual finding was the enhanced hydrogen generation associated with increasing mercury content of the starting sludge. An opposite effect was observed in other tests.

\subsection{Work at the University of Georgia by King et al.}

The work by R. B. King, A. D. King, N. K. Bhattacharyya, Y.-H. Lim, G. Vemparala, V. Vemparala, L. Colletti were summarized in monthly technical reports. Testing was done at the University of Georgia (UGa). The reports are titled "Elucidation of Noble Metal/Formic Acid Chemistry During DWPF Feed Preparation". The reports start in March 1991 and end in January 1992. The reports are numbered from 1-11. Some presentation slide material was found in addition to the written reports. 
Most of the UGa testing was conducted on closed systems, i.e. no purge flow. The resulting concentration-time plots are equivalent to a time integral of the SRNL exit composition-time plot data for continuously purged tests. UGa reported "turnover number", or millimoles $\mathrm{H}_{2} /$ millimole catalyst/24 hours. Unfortunately, the turnover number does not seem to be a constant throughout a given test. Summing the hydrogen evolved over the duration of the tests and converting to turnover number doesn't provide the maximum, or peak, hydrogen generation rate for a given test. Another complication in analysis of the UGa data was that hydrogen generation was on-going at the end of some tests, but nearly non-existent at the end of other tests. Consequently, turnover number is not a reliable measure of potential total hydrogen generation either.

\subsubsection{Report 1 - March 1991}

Various noble metals were evaluated as catalysts for the decomposition/dehydration/oxidation of formic acid in the presence of air. The predominant reaction under these conditions $\left(88 \%\right.$ formic acid at $80^{\circ} \mathrm{C}$ ) was formic acid oxidation by air.

$$
2 \mathrm{HCOOH}+\mathrm{O}_{2} \rightarrow 2 \mathrm{H}_{2} \mathrm{O}+2 \mathrm{CO}_{2}
$$

The marker for this reaction is a depletion of oxygen one half as great as the production of carbon dioxide. (Oxygen depletion has been noted recently during $\mathrm{CO}_{2}$ production periods in simulant tests. It is difficult to track oxygen-depletion with the GC when the depletion is small relative to the oxygen content of air.) UGa tests used one noble metal at a time.

Ruthenium-produced $\mathrm{CO}_{2}$ was distributed roughly as 55\% from oxidation, $37 \%$ from noble metal reduction, and $8 \%$ from decomposition to hydrogen. Rhodium-produced $\mathrm{CO}_{2}$ was virtually $100 \%$ from oxidation (though roughly $4 \%$ must have been derived from noble metal reduction). Palladium-produced $\mathrm{CO}_{2}$ was distributed roughly as $67 \%$ from oxidation and $33 \%$ from noble metal reduction (negligible hydrogen). Silver-produced $\mathrm{CO}_{2}$ was distributed roughly as $44 \%$ from oxidation and $56 \%$ from noble metal reduction (negligible hydrogen).

\subsubsection{Report 2 - April 1991}

The first test reported was the reaction of sodium nitrate with formic acid under an argon blanket. No hydrogen was reported, but $\mathrm{N}_{2} \mathrm{O}, \mathrm{CO}_{2}$, and $\mathrm{CO}$ were produced. The apparatus was either poorly purged or poorly sealed since molecular nitrogen was detected. The second test reported was also the reaction of sodium nitrite with formic acid under an argon blanket. No hydrogen was reported, but $\mathrm{N}_{2} \mathrm{O}$ and $\mathrm{CO}_{2}$ were produced. No CO was detected. A small quantity of "IDMS Sludge" (probably an HM sludge simulant) was added to formic acid at $0^{\circ} \mathrm{C}$ in the third test. No hydrogen was detected. No noble metals were added. $\mathrm{CO}_{2}$ and $\mathrm{N}_{2} \mathrm{O}$ were detected. A small amount of $\mathrm{CO}$ was detected later when the mixture was heated. A larger quantity of IDMS sludge was added to formic acid along with some hydrated ruthenium chloride. Hydrogen production was negligible.

\subsubsection{Report 3 - May 1991}

A description of the "IDMS Sludge" was given. The composition was $25 \% \mathrm{Al}(\mathrm{OH})_{3}, 26 \% \mathrm{Fe}(\mathrm{OH})_{3}, 12 \%$ $\mathrm{NaNO}_{2}, 9.5 \%$ zeolites, $6.6 \% \mathrm{MnO}_{2}, 5 \% \mathrm{SiO}_{2}$ plus a couple dozen minor components. The high nitrite concentration is noteworthy. Tests were run with sludge and $88 \%$ formic acid with a single noble metal chloride trim chemical added. Tests were initially at $\sim 0^{\circ} \mathrm{C}$. Test vessels were initially purged with argon. It appears that the temperature was then increased gradually.

In the run with $\mathrm{RuCl}_{3}$, no significant hydrogen was produced (based on other information, this may have been due to the prolonged induction period of this species, especially when nitrite ion is present). In runs with $\mathrm{PdCl}_{2}$ there was considerable $\mathrm{CO}_{2}$ but only small quantities of other gases including hydrogen. In 
the run with $\mathrm{RhCl}_{3}$ large amounts of $\mathrm{CO}$ and $\mathrm{H}_{2}$ were produced along with various oxides of nitrogen when the temperature neared $80^{\circ} \mathrm{C}$. They then reported that no significant hydrogen was observed in an anaerobic experiment with $\mathrm{RhCl}_{3}$. These two statements appear to be a contradiction, since the original, purportedly argon purged experiment was also anaerobic (free of oxygen). In a further test, doping the system with tin chloride had no inhibiting effect on the hydrogen produced.

\subsubsection{Report 4 - June 1991, Rev. 0 and Rev. 1}

The abstract claims rhodium was active in the presence of nitrite ion. The activity of rhodium was a "surprise" to the UGa researchers. Palladium was active in basic systems. A new IDMS Sludge was described in Rev. 0. The composition was $12 \% \mathrm{Al}(\mathrm{OH})_{3}, 51 \% \mathrm{Fe}(\mathrm{OH})_{3}, 2.5 \% \mathrm{NaNO}_{2}, 1.6 \%$ zeolites, $7.3 \% \mathrm{MnO}_{2}, 3.8 \% \mathrm{ZrO}_{2}, 1.7 \% \mathrm{SiO}_{2}$ plus a couple dozen minor components. (This is obviously a very different sludge from Report 3.) In Revision 1 of Report 4, the composition was changed back to that in Report 3. The following results at $\sim 80^{\circ} \mathrm{C}$ were reported (active means active in producing hydrogen):

1) Ruthenium was active in strong formic acid, dilute formic acid, dilute formic acid/sodium nitrite solutions, and in sodium formate solutions, but activity was not detected in the IDMS sludge.

2) Rhodium was inactive in strong and dilute formic acid, very active in dilute formic acid/sodium nitrite solution and in IDMS sludge, and somewhat active in sodium formate solution.

3) Palladium was inactive in strong formic acid, somewhat active in dilute formic acid, IDMS sludge, and dilute formic acid/sodium nitrite solution, and quite active in sodium formate solution.

EDTA, ethylenediaminetetraacetic acid, complexed the rhodium at a ratio of two moles EDTA per mole rhodium. Mercury, at 7.5 moles $\mathrm{Hg} / \mathrm{mole} \mathrm{Rh}$, significantly reduced hydrogen generated in IDMS sludge versus no mercury. Both palladium and rhodium gave black precipitates in the experiments in dilute formic acid, while the experiment with ruthenium produced a clear yellow-green solution. Palladium and rhodium behaved similarly in the tests with formic acid and nitrite ion (black precipitates), but the ruthenium solution was clear and light red.

All three noble metals gave a black precipitate in the experiments with sodium formate solutions. Adding EDTA to the sodium formate solution appears to have prevented ruthenium precipitation via complexation. Palladium precipitated immediately with and without EDTA present. Rhodium plus EDTA was not tested in sodium formate.

\subsubsection{Report 5 - July 1991}

Low nitrite Purex Sludge simulant was obtained for testing. It was that sludge described in Report 4, Rev. 0, above. The previously used "IDMS Sludge" is now referred to as HM Sludge. The hydrogen turnover number increased by a factor of about 20 from $80^{\circ}$ to $90^{\circ} \mathrm{C}$ in a rhodium catalyzed system. EDTA poisoned $\mathrm{Rh}$ at a mole ratio of 107:1, but was only partially effective at poisoning $\mathrm{Rh}$ at 11:1. Reducing the $\mathrm{Rh}$ addition by a factor of 35 only resulted in $61 \%$ reduction in total hydrogen produced.

Translating these observations to peak hydrogen generations in DWPF is problematic. The hydrogen generation rate was not being measured by UGa. It also appears that hydrogen generation does not start for 25-60 minutes after the clock was started, but this could as easily be the heat-up to temperature time as it could be an induction time. The tests usually ran for about 5-6 hours, but hydrogen was still being generated in many of the tests. The data were adversely affected by the short duration of the tests. No results for ruthenium, palladium, or silver were reported this month. 


\subsubsection{Report 6 - August 1991}

UGa's assessment of the literature and their experimental data were that rhodium-catalyzed decomposition of formic acid was a heterogeneous process. The former hypothesis had been that rhodium was active as a nitro-rhodium complex, such as $\mathrm{Rh}\left(\mathrm{NO}_{2}\right)_{6}{ }^{3-}$.

Eight tests were conducted at $94^{\circ} \mathrm{C}$ on the system $\mathrm{HCOOH} / \mathrm{RhCl}_{3} / \mathrm{NaNO}_{2}$. The ratio $\mathrm{NaNO}_{2} / \mathrm{Rh}$ was varied as follows: 1, 2, 3, 4, 6, $10,20,100$. The reported (average?) hydrogen turnover rate increased with increasing nitrite ion. Hydrogen was primarily evolved in bursts that did not permit rate of generation measurements.

Another interesting finding reported this month was that aeration of the sludge affected the induction period of the rhodium. Fresh, unaerated sludge activated in about two hours. Sludge that had been exposed to air for 6 and 8 days, as well as fresh sludge which was deliberately aerated for 9 days, activated after about seven hours. Simulated Purex sludge was deliberately aerated for further tests.

In a third model system, nitrite ion was found to decompose in formic acid with varying ratios of $\mathrm{NO} / \mathrm{N}_{2} \mathrm{O}$. This system was constructed to assess the relative significance of conversion of nitrite to nitrate (NO produced) versus reduction of nitrite $\left(\mathrm{N}_{2} \mathrm{O}\right.$ produced).

$$
\begin{gathered}
\text { Decomposition: } \\
3 \mathrm{HNO}_{2} \leftrightarrow \mathrm{HNO}_{3}+2 \mathrm{NO}+\mathrm{H}_{2} \mathrm{O} \\
\text { Reduction: } \\
2 \mathrm{HCOOH}+2 \mathrm{HNO}_{2} \leftrightarrow \mathrm{N}_{2} \mathrm{O}+2 \mathrm{CO}_{2}+3 \mathrm{H}_{2} \mathrm{O}
\end{gathered}
$$

In one test with a model system $\mathrm{N}_{2} \mathrm{O}$ exceeded NO. In a second test with some Purex sludge present, NO exceeded $\mathrm{N}_{2} \mathrm{O}$ initially, but ultimately $\mathrm{N}_{2} \mathrm{O}$ exceeded $\mathrm{NO}$. (The above model is now believed to be too simple. Other routes exist to form $\mathrm{NO}$ and $\mathrm{CO}_{2}$ in addition to these.)

\subsubsection{Report 7 - September 1991}

This report was presented orally to TNX personnel. The report was in the form of overhead transparencies copied on paper. Much of the presentation was a summary of Reports 1-6. One new item: nitrilotriacetic acid (NTA) appeared to be a more effective poison than EDTA. EDTA poisoned Rh effectively at about 19:1 mole ratio EDTA/Rh. NTA poisoned effectively at about 6:1 mole ratio NTA/Rh.

The "observations" suggesting rhodium was acting as a heterogeneous catalyst rather than a homogeneous catalyst were summarized as:

- Poor reproducibility of tests

- Variable induction periods

- Apparently random inhomogeneities

\subsubsection{Report 8 - October 1991}

This report further documented results from the testing of NTA poisoning that were presented orally in September. 


\subsubsection{Report 9 - November 1991}

The report discussed work by others, especially Müller (1926, 1929). It recommended a study on using flocculating agents to accelerate colloidal rhodium metal agglomeration into larger, less active particles. (Müller's work has already been discussed in the present document, section 2.1.2.)

\subsubsection{Report 10 - December 1991}

New tests were conducted starting with a nitrite-free simulant sludge. Results were compared to previous tests with HM and Purex sludge simulants containing high and low nitrite ion respectively.

Rhodium was active in the nitrite-free sludge, but the hydrogen produced in the burst of activity increased with increasing initial nitrite ion concentration. Rhodium became active after about one hour in the nitrite-free sludge.

Ruthenium was more active than rhodium in the absence of nitrite ion. Ruthenium activity was only 10$30 \%$ that of rhodium in Purex and HM sludges at the same molar loading (Ru concentration is expected to exceed $\mathrm{Rh}$ concentration in real waste by a factor of 3-4). Ruthenium became active after a long time, $\sim 20$ hours.

Palladium was more active than rhodium in tests with nitrite-free sludge. Palladium became active after about one hour. Palladium was essentially inactive in Purex and HM sludges.

\subsubsection{Report 11 - January 1992}

The issue of homogeneous vs. heterogeneous rhodium catalysis was put back into the unresolved column.

\subsubsection{PNL Slide Presentation - July 7, 1992}

Noble Metal Fission Products as Catalysts for Hydrogen Evolution from Formic Acid used in Nuclear Waste Treatment

This was the title of a presentation given by R. Bruce King to Pacific Northwest Laboratories. A Hanford waste simulant recipe was generated. Sludge simulants were intentionally produced with missing components, e.g. no nitrite; no nitrite and nitrate; no iron; no iron and nitrite; no aluminum; or no aluminum, nitrite, and nitrate. The results:

- $\mathrm{Rh}$ is more active when nitrite ion is present initially.

- Nitrite and nitrate both inhibit Ru activity for hydrogen generation.

- Nitrate has little effect on Ru activity in a nitrite-free system.

- Nitrite and nitrate both inhibit Pd activity for hydrogen generation. Nitrite inhibits better than nitrate.

- $\mathrm{Rh}$ is more active when an iron species is present.

- Uranium $\left(\mathrm{UO}_{2}\left(\mathrm{NO}_{3}\right)_{2} \cdot 6 \mathrm{H}_{2} \mathrm{O}\right)$ was not relevant to hydrogen generation by rhodium.

- The surface of hydrous aluminum oxide enhances the activity of Rh.

- The surface of hydrous aluminum oxide has a negligible effect on Pd activity.

- The surface of hydrous aluminum oxide has a negligible effect on Ru activity.

- $\mathrm{N}_{2} \mathrm{O}$ was found in the palladium-catalyzed system with no initial nitrite, suggesting that Pd catalyzed the reduction of nitrate ion (Note: might this have been denitration by formic acid instead?).

- The activity for ammonia production was $\mathrm{Rh}>\mathrm{Ru}>\mathrm{Pd}$. The overall range of total ammonia production was about a factor of five. 
- When formic acid was metered in, the hydrogen did not appear until after the $\mathrm{N}_{2} \mathrm{O}$ production phase (nitrite destruction) had ended using $\mathrm{Rh}$ as a catalyst. (No comment was included covering the issue that all of the earlier UGa data indicated that Rh was more active when nitrite was present than when it was absent.)

- When formic acid was metered in, the hydrogen appeared as above using Pd as a catalyst, but the amount produced was much less. (No comment was included covering the issue that all of the earlier UGa data indicated Pd was essentially inactive.)

- The buffered system $\mathrm{HCOOH}-\mathrm{HCOONa}-\mathrm{NaNO}_{2}$ produced $\mathrm{CO}_{2}$ and $\mathrm{N}_{2} \mathrm{O}$ when heated, but no NO. Hydrogen appeared when $\mathrm{RhCl}_{3}$ was added following four hours of heating. NO still did not appear.

- Conversely, the buffered system $\mathrm{HCOOH}-\mathrm{HCOONa}-\mathrm{CH}_{3} \mathrm{COOH}-\mathrm{CH}_{3} \mathrm{COONa}-\mathrm{NaNO}_{2}$ (acetic acid and sodium acetate are the two new components) was found to produce both $\mathrm{NO}$ and $\mathrm{N}_{2} \mathrm{O}$ when heated. Hydrogen appeared when $\mathrm{RhCl}_{3}$ was added following four hours of heating.

It is not stated who funded these additional experiments that must have been performed in the spring of 1992. Nonetheless, they significantly expand on the results reported in the eleven monthly technical reports.

\subsubsection{Chemical Pretreatment of Nuclear Waste, (King et al.)}

This book is a proceedings from an American Chemical Society meeting held in August of 1992. There is a chapter titled "Noble Metal Fission Products as Catalysts for Hydrogen Evolution from Formic Acid Used in Nuclear Waste Management" by R. B. King, A. D. King Jr., N. K. Bhattacharyya, C. M. King, and L. F. Landon. It summarizes many of the findings in the eleven monthly reports discussed above.

\subsubsection{Inorganica Chimica Acta, 237, 1995 (King and Bhattacharyya)}

This paper continues the documentation of work at UGa. The title is "Catalytic reactions of formate 4. A nitrite-promoted rhodium (III) catalyst for hydrogen generation from formic acid in aqueous solution". (The third article in the series was not obtained, but it was submitted to Transition Met. Chem.) The fourth paper details evidence that the addition of $\mathrm{RhCl}_{3} \cdot 3 \mathrm{H}_{2} \mathrm{O}$ can lead to the formation of $\mathrm{Rh}\left(\mathrm{NO}_{2}\right)_{6}{ }^{3-}$. This species was active toward the catalytic decomposition of formic acid. The kinetics were pseudo-first order in Rh, supporting a homogeneous catalyst more than a heterogeneous catalyst. A color change was observed adding orange $\mathrm{RhCl}_{3} \cdot 3 \mathrm{H}_{2} \mathrm{O}$ in water to formic acid giving a clear final solution. Loss of activity toward hydrogen generation was attributed to the conversion of the nitrorhodium complex to less active metallic rhodium. Three of the six groups on the nitrorhodium complex are "labile", i.e. readily interchangeable with other ligands. The authors argue that formate ion occupies one of the sites during decomposition. The presence of soluble copper as $\mathrm{Cu}^{2+}$ altered the mixture of nitrogen oxides formed and somewhat inhibited hydrogen formation (argon inert atmosphere).

\subsubsection{Env. Sci. and Tech., 30, 1996 (King, Bhattacharyya, and Wiemers)}

In this paper the work of Karen Wiemers, section 2.1.6, merges with that being done at the University of Georgia. There are three papers in this group. The title of this one was "Noble Metal Catalyzed Hydrogen Generation from Formic Acid in Nitrite-Containing Simulated Nuclear Waste Media". A very simple NCAW simulant was used. The authors conclude through careful titration and off-gas monitoring that carbonate destruction precedes nitrite ion reduction which precedes hydrogen generation. (This is consistent with results of WSRC tests on SRS wastes.) The authors present data indicating that palladium is an active catalyst for the reduction of nitrate to $\mathrm{N}_{2} \mathrm{O}$ via formic acid. This occurred only after nitrite ion was destroyed or when it was never added to the simulant. 
The authors report that stoichiometric amounts of nitrite are sufficient to form the nitrorhodium catalyst described in the previous article (six nitrite ions per rhodium atom). No excess nitrite is required. The rate of hydrogen generation was roughly three times higher at $94^{\circ} \mathrm{C}$ than at $89^{\circ} \mathrm{C}$ or $88^{\circ} \mathrm{C}$. Experiments starting with hydrated ruthenium chloride showed negligible hydrogen production over 15 hours at temperature. Hydrogen was only seen with $\mathrm{Ru}$ when nitrite was not included in the sludge.

\subsubsection{Env. Sci. and Tech., 31, 1997 (King, Bhattacharyya, Smith, and Wiemers)}

This paper primarily deals with ammonia generation. The title is "Noble Metal-Catalyzed Ammonia Generation by Formic Acid Reduction of Nitrate in Simulated Nuclear Waste Media". The authors' findings conclude that

1) The investigation was prompted by the formation of unexplainably large amounts of carbon dioxide compared to the requirements for acid neutralization, nitrite destruction, manganese reduction, and hydrogen formation.

2) Nitrate ion, rather than nitrite ion, is the primary source of nitrogen in ammonia.

3) When ammonia forms, it is at the expense of hydrogen.

4) Supported metallic rhodium is a more active catalyst than nitrorhodium complexes. The complexes did not appear to be particularly reactive toward ammonia formation.

5) Final $\mathrm{pH}$ was generally higher when ammonia was formed (nearer to 7 than 4 ).

6) Conditions for the nearly full reduction of $\mathrm{Fe}(\mathrm{III})$ to $\mathrm{Fe}(\mathrm{II})$ were found when using rhodium supported on carbon as a catalyst.

Some of the above is interesting from the standpoint of the 2001-2002 simulant work with Sludge Batch 2 (Macrobatch 3) and fairly high noble metal loadings, section 2.7.6. In these runs there was generally an unusual amount of carbon dioxide formation and the SRAT product $\mathrm{pH}$ was around 7 . The SRAT product, however, was not checked for ammonia/ammonium ion. Ammonia was not found in Sludge Batch 1B simulant tests.

\subsubsection{Env. Sci. and Tech., 32, 1998 (King, Bhattacharyya, Smith, and Wiemers)}

This paper, entitled "Redox Potential Monitoring as a Method to Control Unwanted Noble MetalCatalyzed Hydrogen Generation from Formic Acid Treatment of Simulated Nuclear Waste Media", was the last of the three found in this journal. The authors noted that hydrogen generation did not commence until the redox potential relative to the $\mathrm{Ag} / \mathrm{AgCl}$ electrode fell from about $+400 \mathrm{mV}$ to less than $0 \mathrm{mV}$. They suggest that limiting acid addition based on redox potential could be a way of limiting hydrogen generation.

\subsubsection{Commentary on Relevant UGa Findings}

The issue of which noble metal is critical and in what form remains open, but $\mathrm{Rh}$ is the leading candidate with $\mathrm{Rh}\left(\mathrm{NO}_{2}\right)_{6}{ }^{-3}$ being the potentially most active form. A complex role for nitrite was indicated at any level near or above six moles nitrite per mole Rh. This situation typically prevails in the SRAT during acid addition and into the boiling period. Pd was seen as least active in a sludge matrix, consistent with C. W. Hsu's single noble metal tests using formic acid only. Restrictions on Ru activity related to nitrite ion concentration. These might support Ru becoming active after long processing times that effectively eliminate all nitrite. Sludge aeration time was cited as a potential factor in setting the induction time of $\mathrm{Rh}$. 
Tests with metered acid addition showed hydrogen appearing after the $\mathrm{N}_{2} \mathrm{O}$ had been generated, which is consistent with historical SRNL data. In addition to hydrogen generation, UGa observed reactions that are now collectively referred to as catalytic wet air oxidation. The complexing agents EDTA and NTA were investigated as two potential catalyst poisons. The quantities required to effectively poison the noble metals were considerably higher in a sludge matrix than in an aqueous solution. This may be due to competition for the complexing agents from other metal ions.

Report 4 cites mercury as a poison for hydrogen generation. This is the opposite of the result found by Hsu, Section 2.3.5. The discussion of palladium as a catalyst for ammonia formation is unique. The link between nitrate, palladium, and ammonia is significant. Some testing showed little hydrogen generation when $\mathrm{Pd}$ was present without $\mathrm{Rh}$ and $\mathrm{Ru}$, but testing in pure formic acid showed Pd was more active than either. Nitrate in SRS sludge may be inhibiting Pd from acting as a decomposition catalyst for hydrogen.

\subsection{Simulant Work in IDMS}

Early IDMS runs were primarily summarized in the "Integrated DWPF Melter System (IDMS) Campaign Reports". Later IDMS runs were summarized in topical reports addressing a specific concern such as mercury, ammonia, the Late Wash/Nitric Acid flowsheet, etc. IDMS test runs were given shorthand names. These were comprised of two-four letters followed by a number.

A brief list of IDMS test run code letters:

$\begin{array}{ll}\text { BL } & \text { blended sludge run (blend of Purex and HM simulants) } \\ \text { HG } & \text { mercury test run } \\ \text { PHA } & \text { run with PHA addition (HAN/Formic Acid flowsheet) } \\ \text { PX } & \text { Purex sludge run } \\ \text { HM } & \text { HM sludge run } \\ \text { HWVP } & \text { Hanford Waste Vitrification Plant run }\end{array}$

Table 7 is an attempt to reconstruct the sequence of runs in IDMS using site waste simulants. The two special runs with Hanford waste simulant are given last although they occurred in the middle of the DWPF test sequence. 
Table 7 - IDMS Run Summary

\begin{tabular}{|l|c|c|c|c|l|}
\hline \multicolumn{1}{|c|}{ Run } & Date & $\begin{array}{c}\text { Noble } \\
\text { Metals }\end{array}$ & $\begin{array}{c}\text { Peak H2, } \\
\text { pph DWPF }\end{array}$ & Flowsheet & Comments \\
\hline Sludge1 & & none & - & no PHA & Start-up tests \\
\hline Sludge2 & & none & - & no PHA & Start-up tests \\
\hline PHA1 & $\sim 4 / 89$ & none & - & HAN-FA & Coupled process demo \\
\hline PHA2 & & none & - & HAN-FA & Coupled process demo \\
\hline PHA3 & $\sim 12 / 89$ & none & - & HAN-FA & Coupled process demo \\
\hline HG1 & & none & - & HAN-FA & \\
\hline HG2 & & none & - & HAN-FA & \\
\hline HG3 & & none & - & HAN-FA & \\
\hline BL1 & 990 & Blend & $<0.015$ & HAN-FA & \\
\hline BL2 & $990-91$ & Blend & 0.91 & HAN-FA & SME heel present \\
\hline BL3 & $4 / 91$ & none & - & HAN-FA & DWPF cold run demo \\
\hline HM1 & $5 / 91$ & none & - & HAN-FA & DWPF cold run demo \\
\hline HM2 & 991 & HM & 0.29 & HAN-FA & \\
\hline HM3 & 991 & HM & 0.07 & HAN-FA & 22 vol. \% SME heel \\
\hline PX1 & $' 91$ & PX & 0.85 & HAN-FA & \\
\hline PX2 & $' 91$ & HM & 1.5 & HAN-FA & 25\% acid overbatching; \\
& & & & & des. basis for HAN-FA \\
\hline HM4 & $2-3 / 92$ & HM & 0.07 & HAN-NA & \\
\hline PX3 & $5 / 92$ & HM & 0.11 & HAN-NA & \\
\hline PX4 & $7 / 92$ & HM & 0.20 & LW-NA & "nominal" \\
\hline PX5 & $10 / 92$ & HM & 0.64 & LW-NA & max credible deviations; \\
& & & & Lesign basis for LW-NA \\
\hline PX6 & $12 / 93$ & HM & 0.24 & LW-NA & "nominal", hi NO ${ }_{2}^{-}$ \\
\hline PX7 & $12 / 94$ & HM & $?$ & LW-NA & "nominal", hi NO ${ }_{2}^{-}$ \\
\hline HWVP1 & $11 / 91$ & NCAW'91 & 1 & Hanford & Hanford Waste, lo NO ${ }_{2}^{-}$ \\
\hline HWVP2 & $12 / 91$ & NCAW'91 & 0.04 & Hanford & Hanford Waste, hi NO ${ }_{2}^{-}$ \\
\hline
\end{tabular}

The original HM and Purex worst case noble metal bases for IDMS sludge simulants were nearly identical. The reference for the noble metal bases is J. R. Fowler, 1987, DPST-87-0713 as late as PX6. It was not clear why some of the noble metal bases were adjusted from the original values of early 1991 for HM and Purex sludges to the HM worst case basis concentrations that became standard in the later IDMS runs. It is clear that there was a desire to document hydrogen generation rates at the worst case noble metal concentrations.

Sludge1-Sludge2 are documented in WSRC-RP-89-0321. PHA1-PHA3 are documented in WSRC-TR90-131. HG1-HG3 are documented in WSRC-TR-91-0363. BL3 and HM1 were DWPF cold run demonstrations without noble metals documented in WSRC-RP-93-593. BL1 and BL2 were the first two IDMS runs with noble metals, WSRC-TR-91-400. Hanford simulant runs HWVP1 and HWVP2 were documented in WSRC-TR-92-0403, Rev. 1. It appears that two bench-scale and two IDMS runs were performed with noble metals at the NCAW'91 basis values. The HWVP runs followed PX2 and preceded HM4 in the IDMS run chronology.

The noble metal basis changed during the period of IDMS operation. Table 8 below gives some data. 
WSRC-TR-2002-00034

Revision 0

Table 8 - Changing Noble Metal Bases During IDMS Campaigns, wt. \% Dry

\begin{tabular}{|l|l|l|l|l|l|l|}
\hline Element & $\begin{array}{c}\text { HM Re- } \\
\text { revised }^{2}\end{array}$ & $\begin{array}{c}\text { Purex } \\
\text { Revised }^{1}\end{array}$ & $\begin{array}{c}\text { HM } \\
\text { Revised }^{1}\end{array}$ & $\begin{array}{c}\text { Blend } \\
\text { Basis }^{1}\end{array}$ & Purex Basis & HM Basis \\
\hline $\mathrm{Hg}$ & 3.263 & 0 & 0 & 1.588 & 0.0036 & 1.166 \\
\hline $\mathrm{Ag}$ & 0.014 & 0.014 & 0.015 & 0.014 & 0.014 & 0.014 \\
\hline $\mathrm{Pd}$ & 0.079 & 0.079 & 0.085 & 0.045 & 0.026 & 0.079 \\
\hline $\mathrm{Rh}$ & 0.038 & 0.038 & 0.041 & 0.018 & 0.008 & 0.038 \\
\hline $\mathrm{Ru}$ & 0.217 & 0.239 & 0.217 & 0.100 & 0.028 & 0.217 \\
\hline
\end{tabular}

1 - WSRC-MS-92-017

2 - WSRC-TR-94-0556

The three right-hand columns seem to be the original bases for the three types of waste simulant. The Purex basis was also "re-revised" like the HM basis to include mercury at 0.102 wt. \%. The "re-revised" HM ruthenium apparently was returned to $0.217 \%$ later. Table 9 details the mercury and noble metal concentrations in those IDMS runs that included noble metals.

Table 9 - Noble Metals, Mercury, and Nitrite in Selected IDMS Runs

\begin{tabular}{|l|c|c|c|c|c|c|c|}
\hline Run & $\begin{array}{c}\text { Rh } \\
\text { wt. \% }\end{array}$ & $\begin{array}{c}\text { Ru } \\
\text { Wt. \% }\end{array}$ & $\begin{array}{c}\text { Pd } \\
\text { wt. \% }\end{array}$ & $\begin{array}{c}\mathrm{Ag} \\
\text { wt. \% }\end{array}$ & $\begin{array}{c}\mathrm{Hg} \\
\text { wt. \% }\end{array}$ & $\begin{array}{c}\mathrm{NO}_{2} \text {-init } \\
\text { ppm }\end{array}$ & $\begin{array}{c}\text { Sludge } \\
\text { init-gal }\end{array}$ \\
\hline BL1 & 0.0186 & 0.104 & 0.046 & 0.015 & 1.02 & 15000 & 1170 \\
\hline BL2 & 0.0189 & 0.105 & 0.045 & 0.014 & 1.03 & 12000 & 1100 \\
\hline HM2 & $(0.041)$ & $(0.217)$ & $(0.085)$ & $(0.015)$ & $(0)$ & $(14000)$ & 1100 \\
\hline HM3 & $(0.041)$ & $(0.217)$ & $(0.085)$ & $(0.015)$ & $(0)$ & $(14000)$ & 1420 \\
\hline PX1 & $(0.038)$ & $(0.239)$ & $(0.079)$ & $(0.014)$ & $(0)$ & $(3000)$ & 1030 \\
\hline PX2 & 0.038 & 0.22 & 0.079 & 0.014 & 0 & $\sim 3000$ & 1140 \\
\hline HM4 & 0.038 & 0.239 & 0.079 & 0.014 & 3.2 & $\sim 12000$ & 1100 \\
\hline PX3 & 0.038 & 0.239 & 0.079 & 0.014 & 3.2 & 0 & 1100 \\
\hline PX4 & 0.039 & $0.23 \pm$ & 0.080 & 0.014 & $3.2-3.5$ & $\sim 4000$ & 1100 \\
\hline PX5 & 0.038 & 0.239 & 0.079 & 0.014 & $3.2-3.5$ & $\sim 3000$ & 1100 \\
\hline PX6 & 0.038 & 0.217 & 0.079 & 0.014 & 3.263 & $\sim 17000$ & 1100 \\
\hline PX7 & 0.038 & 0.217 & 0.079 & 0.014 & 3.263 & $\sim 17000$ & 1100 \\
\hline HWVP1 & 0.064 & 0.268 & 0.080 & 0.085 & 0 & 3782 & $(1100)$ \\
\hline HWVP2 & 0.064 & 0.268 & 0.080 & 0.085 & 0 & 18514 & $(1100)$ \\
\hline
\end{tabular}

Numbers in parentheses indicate "nominal values" for a given sludge, that were not confirmed by any of the individual run information located during this search. Some information for PX6 and PX7 gave nitrite as $0.398 \mathrm{M}$ and $0.389 \mathrm{M}$ respectively (possible transcription error). Some data for PX7 suggest that noble metals were actually $0.8453^{*} \mathrm{Rh}, 0.846^{*} \mathrm{Ru}, 0.76^{*} \mathrm{Pd}, 0.845^{*} \mathrm{Ag}$, and $0.908^{*} \mathrm{Hg}$ in Table 9 above. Initial volumes of sludge were by various measures (or averages of various measures). Various measures for PX6 batch size range from 1007-1180 gallons. Similar data for PX7 vary from 1061-1250 gallons.

The information/data found on the various IDMS runs varied greatly in content, particularly in the level of detail that was discussed. The following information, Table 10, was collected in case there was a reason to attempt a calculation of the acid stoichiometry using the contemporary spreadsheet calculations. Peak hydrogen was originally reported at DWPF scale, so no further conversions were required. 
Table 10 - Peak Hydrogen, Nitrite, and Acid Additions

\begin{tabular}{|c|c|c|c|c|c|c|}
\hline Run & $\begin{array}{c}\text { Peak } \mathrm{H}_{2} \\
\text { lb./hr }\end{array}$ & $\begin{array}{l}\mathrm{NO}_{2} \text {-init } \\
\text { ppm }\end{array}$ & $\begin{array}{l}\text { Formic } \\
\text { gallons }\end{array}$ & $\begin{array}{l}\text { Nitric } \\
\text { gallons }\end{array}$ & $\begin{array}{c}\text { PHA } \\
\text { gallons }\end{array}$ & Hydrogen Peaked ${ }^{3}$ \\
\hline BL1 & $<0.015$ & 15000 & 32 & 0 & 1983 & (no data for P, PR) \\
\hline BL2 & 0.91 & 12000 & 60 & 0 & 1330 & $+13 \mathrm{hrs}, \mathrm{R}$ \\
\hline HM2 & 0.29 & (14000) & 31 & 0 & $?$ & +22 hrs?, PR \\
\hline HM3 & 0.07 & (14000) & 26 & 0 & $?$ & +37 hrs?, PR \\
\hline PX1 & 0.85 & (3000) & 36 & 0 & $?$ & +14 hrs?, P? \\
\hline PX2 & 1.5 & $\sim 3000$ & 45 & 0 & $?$ & +28 hrs?, PR? \\
\hline HM4 & 0.07 & $\sim 12000$ & 0 & 69 & 2150 & $+125 \mathrm{hrs}, \mathrm{PR}$ \\
\hline PX3 & 0.11 & 0 & 0 & $?$ & $?$ & no time resolved data \\
\hline PX4 & 0.20 & $\sim 4000$ & 0 & 35 & 2000 & +79 hrs, $\mathrm{P}$ \\
\hline PX5 & 0.64 & $\sim 3000$ & 0 & $38-45$ & $2075^{1}$ & $+44 \mathrm{hrs}, \mathrm{PR}$ \\
\hline PX6 & 0.24 & $\sim 17000$ & 0 & 63.4 & $?$ & $+50 \mathrm{hrs}, \mathrm{P} / \mathrm{PR}$ \\
\hline PX7 & $?$ & $\sim 17000$ & 0 & 46 & $?$ & $?$ \\
\hline HWVP1 & 1 & 3782 & $38^{2}$ & $\overline{0}$ & 0 & $+8 \mathrm{hrs}, \mathrm{R}$ \\
\hline HWVP2 & 0.04 & 18514 & $56^{2}$ & 0 & 0 & $+10 \mathrm{hrs}, \mathrm{R}$ \\
\hline
\end{tabular}

Formic acid was nominally 90 wt. \%. Nitric acid may have been 8M in HM4 and in PX3-PX5. PX6 used $11 \mathrm{M}$ nitric acid. PX7 used a mixture of 10.5M and 11M nitric acid. HM3 had a heel leftover from HM2. The PHA used in PX3 was spiked with additional formic acid. PX7 PHA was spiked with ammonium nitrate. PX4 used late wash PHA.

Too much of the run data collected was from second-hand sources, such as manuscripts for conferences, etc. It does not appear to be possible to reconstruct the stoichiometric acid volume for most of the runs from these data sources, or to calculate a percent acid stoichiometric excess. Too often one or two necessary pieces of information were missing, e.g. sludge composition (wt. \% solids or Mn), acid molarity, PHA molarity, or volume PHA added, etc.

What is clear is that PX2 and PX5 were intended to be bounding cases for hydrogen generation, PX2 for the HAN/Formic Acid flowsheet, and PX5 for the Late Wash/Nitric Acid flowsheet. WSRC-RP-93-1039 describes the preliminary plan for PX6 and PX7. Both runs were originally envisioned as nominal runs under identical conditions to test the reproducibility of data. These conditions were to include HM levels of mercury and noble metals, plus high nitrite ion concentration.

Notable features of the two Hanford simulant tests include both the lack of mercury and the high noble metal concentrations (above HM levels). HWVP1 was 0.1M nitrite and HWVP2 was 0.37M nitrite. There were small differences in manganese, nickel hydroxide, etc. between the two runs as well. The acid addition for the second run was actually a lower percent excess acid than the first run, in spite of the larger volume. The HWVP1 peak hydrogen generation rate agreed well with the two supporting benchscale results at similar initial nitrite concentration and two different acid loadings. These scaled to 0.14 and $0.54 \mathrm{lb} / \mathrm{hr}$ for the same basis. The HWVP runs were different from either the HAN/FA or Late Wash/NA flowsheets used in the DWPF simulant tests. For example, they included a recycle waste stream addition sometime after formic acid addition. 
SRAT/SME simulant testing immediately following the conclusion of the IDMS campaigns shifted to bench-scale work, discussed in section 2.7.1 and following, and to the $1 / 200^{\text {th }}$ scale SRAT in 672-T also discussed in section 2.7.1. The $1 / 200^{\text {th }}$ scale SRAT was a metal mini-pilot plant built in a lab hood to give a larger-scale capability than typical bench top work. One document was found concerning testing in this facility, WSRC-RP-94-819. This reported on the impact of the change from copper formate to copper nitrate in hydrolysis operations to SRAT processing. The test(s) were with Purex sludge containing mercury and HM levels of noble metals. Hydrogen generation data were not reported in the document above.

\subsubsection{Commentary on IDMS Hydrogen Data}

IDMS testing confirmed that hydrogen generation is as significant at larger scales as it is at laboratory scales. Data from IDMS were used to set some of the design bases for DWPF. Extracting fundamental information about hydrogen generation from this data would be hindered by certain operational aspects of the IDMS control system. In particular, the control interlock between the two GC's that were sampling the off-gas in parallel triggered numerous steam flow interruptions that disrupted the off-gas evolution as a function of time. Such issues make each run unique. Bench-scale studies using simpler equipment avoid such issues most of the time. This makes a given bench-scale SRAT/SME simulation potentially more reproducible. The enhanced reproducibility of bench-scale runs strengthens conclusions drawn from comparisons between two or more runs.

\subsection{Shielded Cells Testing}

This section discusses process simulations made in the SRTC Shielded Cells facility, or in the course of developing equipment for these runs. There were two main periods of testing. The first was from 19911992. The second was the period of sludge batch qualification work. Some minor testing was performed between these two periods.

Twenty four SRAT runs were made with $100 \mathrm{~mL}$ volumes of sludge in 1991-1992, sections 2.6 .1 and 2.6.2. All but a few of these runs were made in the Shielded Cells facility in SRNL (some simulant demonstration runs were made outside the Cells before the apparatus was moved into the Cells). The radioactive runs included fourteen SRAT cycles with waste samples from Tanks 4, 11, 15, and 51. There were ten SRAT cycles with simulated sludge. The first eighteen runs were based on the HAN/FA flowsheet. They occurred in 1991. The last six runs were intended to demonstrate the LW/NA flowsheet. They occurred in 1992. Laboratory notebooks detailing these 24 runs were being kept by Daro Ferrara. Relevant notebook numbers are listed throughout the discussion that follows. Every run had noble metals and detectable hydrogen evolution.

These 24 runs were purged with $10 \mathrm{sccm}$ of argon. This was about $43 \%$ of the scaled nominal $188 \mathrm{scfm}$ air purge. A $1 \%$ hydrogen concentration at this scale and air purge corresponds to $0.270 \mathrm{lbs} / \mathrm{hr}$ when scaled to 6000 gallons. (Some researchers have made a second correction to the scaled DWPF hydrogen generation rate by multiplying by the ratio of ( $19 \mathrm{wt}$. $\%$ solids $) /($ actual wt. $\%$ solids $)$. That would be a fairly significant adjustment to some of the real waste data below that was processed at $<10 \mathrm{wt}$. $\%$ total solids.)

These tests were followed by some interim tests, section 2.6.3. Additional tests were conducted in support of each sludge batch processed in DWPF. This report covers testing for sludge batches 1A, 1B, and 2 in sections $2.6 .4,2.6 .5$, and 2.6.6 respectively.

Data from radioactive sludges are used to set the noble metal concentrations in simulant work. N. E. Bibler, WSRC-TR-2005-00098, has documented the proportions of the three major noble metals that 
were expected as ${ }^{235} \mathrm{U}$ fission products. These are in the proportions of $3.7 \mathrm{Ru}$ to $1.0 \mathrm{Rh}$ to $0.54 \mathrm{Pd}$ by mass based on their fission yields. This assumes that there are no other sources for the noble metals besides ${ }^{235} \mathrm{U}$ fission. These yields were in turn based on the $15^{\text {th }}$ edition of Parrington et al.'s Chart of the Nuclides (1996).

The palladium content of sludge seems to be more affected by post-neutralization decanting or washing operations in the tank farm than the other two noble metals, WSRC-TR-2004-00196. Palladium seems to fall below 0.54 relative to $\mathrm{Rh}$ in waste sludge due to its higher solubility. Conversely, $\mathrm{Pd}$ may be enriched in the salt tanks relative to $\mathrm{Ru}$ and $\mathrm{Rh}$.

Noble metals in the real waste sludges have been analyzed by both ICP-MS and ICP-AES (see Table 11, Table 13, and Table 14 below). These data support a Ru to Rh ratio of about four. The Purex and HM design bases, Table 8 , have a $\mathrm{Ru} / \mathrm{Rh}$ ratio of about six for simulant work. This could tend to understate $\mathrm{Rh}$ or overstate $\mathrm{Ru}$. The two design bases also have a Pd to $\mathrm{Rh}$ ratio of about two, instead of a $\mathrm{Rh}$ to $\mathrm{Pd}$ ratio of about two. The fission yields and the analytical data below do not support a four-fold increase in $\mathrm{Pd}$ relative to $\mathrm{Rh}$.

\subsubsection{Program One, 1991}

The first 18 runs were overseen by B. C. Ha, WSRC-NB-91-142, WSRC-NB-92-138, and WSRC-NB-92260. All runs used formic acid plus a PHA simulant stream. In one run the PHA was added first, and the formic acid was added second. Otherwise, formic acid was metered in at $93-95^{\circ} \mathrm{C}$, the SRAT was then boiled for about six hours, then PHA was added at boiling in increments over several hours, and finally the SRAT was refluxed, generally at least until the hydrogen generation rate had peaked and started to fall.

The measured compositions, wt. \% dry sludge basis, of two of the real sludges were given in WSRC-MS92-109 and again in WSRC-MS-92-109X: 
Table 11 - Sludge Compositions for Two of the Sludges Used in 1991 Tests

\begin{tabular}{|l|c|c|}
\hline Species & Tank 4 & Tank 15 \\
\hline $\mathrm{Fe}$ & 24.3 & 4.9 \\
\hline $\mathrm{Al}$ & 1.8 & 30.8 \\
\hline $\mathrm{Na}$ & 12.1 & 2.4 \\
\hline $\mathrm{Mn}$ & 1.4 & 2.5 \\
\hline $\mathrm{U}$ & 6.2 & 0.045 \\
\hline $\mathrm{Ca}$ & 0.64 & 0.21 \\
\hline $\mathrm{Mg}$ & 0.06 & 0.15 \\
\hline $\mathrm{Si}$ & 0.02 & 0.19 \\
\hline $\mathrm{P}$ & 0.29 & 0.3 \\
\hline $\mathrm{Ni}$ & 5.2 & 0.46 \\
\hline $\mathrm{Ti}$ & 0.01 & 0.02 \\
\hline $\mathrm{Cr}$ & 0.12 & 0.02 \\
\hline $\mathrm{Hg}$ & 0.03 & 2.5 or 4.5 \\
\hline $\mathrm{Th}$ & 0.001 & 0.23 \\
\hline $\mathrm{Ag}$ & 0.002 & 0.0003 or 0.0007 \\
\hline $\mathrm{Pd}$ & 0.006 & 0.002 or 0.005 \\
\hline $\mathrm{Rh}$ & 0.025 & 0.013 or 0.030 \\
\hline $\mathrm{Ru}$ & 0.115 & 0.064 or 0.10 \\
\hline
\end{tabular}

The Tank 15 "or" numbers came from WSRC-MS-92-109X. (The Tank 4 numbers matched between the two reports.) The ten runs with simulant sludges are characterized in Table 12 below, and the eight runs with radioactive sludge are described later, Table 13. The PHA used in these tests contained the equivalent of $0.08 \mathrm{M}$ formic acid and $13,000 \mathrm{ppm}$ of formate. 
WSRC-TR-2002-00034

Revision 0

Table 12 - Small Scale SRAT Tests With Simulants in 773-A, 1991

\begin{tabular}{|l|c|c|c|c|c|c|c|c|c|c|}
\hline Sludge & Purex & HM2 & Purex & HM & Purex & HM & HM2 & Purex & Purex & Purex \\
\hline Solids, wt. \% & 12 & 14 & 12 & 14 & 12 & 14 & 14 & 12 & 12 & 12 \\
\hline${\mathrm{M}, \mathrm{OH}^{-}}^{-}$ & 0.11 & 0.06 & 0.11 & 0.06 & $0.6^{1}$ & 0.06 & 0.06 & 0.11 & 0.029 & $0.53^{2}$ \\
\hline${\mathrm{M}, \mathrm{NO}_{2}^{-}}^{-}$ & 0.072 & 0.33 & 0.072 & 0.33 & 0.32 & 0.33 & 0.33 & 0.072 & 0.32 & 0.07 \\
\hline $\mathrm{Hg}$, wt. \% & 0 & 0 & 0 & 0 & 0 & 0 & 0 & 0 & 0 & 0 \\
\hline $\mathrm{Ag}$, wt. \% & 0.013 & 0.013 & 0.013 & 0.013 & 0.013 & 0.013 & 0.013 & 0.013 & 0.013 & 0.013 \\
\hline Pd, wt. \% & 0.073 & 0.073 & 0.073 & 0.073 & 0.073 & 0.073 & 0.073 & 0.073 & 0.073 & 0.073 \\
\hline Rh, wt. \% & 0.035 & 0.035 & 0.035 & 0.035 & 0.035 & 0.035 & 0.035 & 0.035 & 0.035 & 0.035 \\
\hline Ru, wt. \% & 0.22 & 0.22 & 0.22 & 0.22 & 0.22 & 0.22 & 0.22 & 0.22 & 0.22 & 0.22 \\
\hline Acid, ml & 3.2 & 3.0 & 3.2 & 2.6 & $6 / 7.5$ & 3 & 3 & 3.1 & 4.5 & 6.2 \\
\hline PHA, ml & 120 & $120^{3}$ & 120 & 120 & 120 & 120 & 118 & 120 & 120 & 120 \\
\hline Max H, vol\% & 0.54 & 0.585 & 0.67 & 0.795 & 0.86 & 1.2 & 1.2 & 1.3 & 1.3 & 1.6 \\
\hline Max flow, pph & 0.15 & 0.16 & 0.18 & 0.21 & 0.23 & 0.32 & 0.32 & 0.35 & 0.35 & 0.43 \\
\hline Max Time, hr & 21 & 16 & 18 & 14 & 20 & 3.2 & 16 & 13 & 15 & 14 \\
\hline Max pH & - & 5.49 & 5.6 & - & 6.4 & - & 4.9 & - & 4.2 & 6.8 \\
\hline Min SRAT pH & - & 3.4 & 3.7 & - & 4.4 & - & 3 & - & 3.8 & 4.7 \\
\hline Final SRAT pH & 6.3 & 5.7 & 5.6 & 7.3 & 6.5 & 7.3 & 5.36 & 6.9 & 4.5 & 7.1 \\
\hline Code: HY-91- & 14 & $26^{3}$ & 15 & 10 & $23^{1}$ & 9 & 25 & 11 & 21 & $13^{2}$ \\
\hline
\end{tabular}

1 - Spiked with $\mathrm{NaOH}$ and $\mathrm{NaNO}_{2}$, maximum hydrogen was the last data point.

2 - Spiked with $\mathrm{NaOH}$.

3 - This PHA was added first, and the formic acid was added second.

4 - DWPF scale, calculated by author, and not adjusted for wt. \% solids.

WSRC-RP-92-109X gives the typical simulant noble metal concentrations as $0.015 \% \mathrm{Ag}, 0.075 \% \mathrm{Pd}$, $0.048 \% \mathrm{Rh}$, and $0.18 \% \mathrm{Ru}$. These are close to the above values. HM2 sludge was IDMS sludge used in the HM2 run of IDMS. The SRAT test runs occurred chronologically in ascending code number order (last row of table). This applies both to Table 12 and Table 13. HY-91-9 was first. HY-91-29, Table 13, was last.

The Tank 11 and 15 real sludges were untreated in early runs. In later runs these two sludges were treated with $\mathrm{NaOH}$ and washed with inhibited water to remove aluminum. Tank 4 and 51 sludges do not appear to have been treated in this manner. Table 13 summarizes the eight 1991 test runs with radioactive sludge waste. (The maximum hydrogen flow, pph, row was calculated for this report by adjusting the other data to DWPF scale.) 
WSRC-TR-2002-00034

Revision 0

Table 13 - Small Scale SRAT Tests With Real Waste in 773-A, 1991

\begin{tabular}{|l|c|c|c|c|c|c|c|c|}
\hline Sludge & Tk 51 & Tk 15 & Tk 15 & Tk 15 & Tk 11 & Tk 11 & Tk 11 & Tk 4 \\
\hline Solids, wt. \% & 12.5 & 13 & 8.7 & 13 & 9 & 9 & 12 & 13 \\
\hline${\mathrm{M}, \mathrm{OH}^{-}}^{-}$ & 0.033 & 0.7 & 0.24 & $0.05-6$ & 0.12 & 0.1 & 0.62 & 0.09 \\
\hline${\mathrm{M}, \mathrm{NO}_{2}}^{-}$ & 0.055 & 0.3 & 0.37 & 0.3 & 0.32 & 0.32 & 0.33 & 0.1 \\
\hline $\mathrm{Hg}$, wt. \% & 0.02 & 2.5 & 2.5 & 2.5 & 4.5 & 4.5 & 4.5 & 0.03 \\
\hline $\mathrm{Ag}$, wt. \% & 0.01 & 0.0003 & 0.0007 & 0.0003 & 0.0007 & 0.0007 & 0.0007 & 0.002 \\
\hline Pd, wt. \% & 0.0004 & 0.002 & 0.005 & 0.002 & 0.006 & 0.006 & 0.006 & 0.006 \\
\hline Rh, wt. \% & 0.001 & 0.013 & 0.030 & 0.013 & 0.03 & 0.03 & 0.03 & 0.025 \\
\hline Ru, wt. \% & 0.005 & 0.064 & 0.10 & 0.064 & 0.1 & 0.1 & 0.1 & 0.12 \\
\hline Acid, ml & 1.5 & 6 & 3.7 & 2.9 & 2.1 & 3.5 & 4.6 & 2.5 \\
\hline PHA, ml & 120 & 120 & 145 & 120 & 120 & 120 & 120 & $120 ?$ \\
\hline Max $\mathrm{H}_{2}$, vol\% & $0.012^{1}$ & 0.05 & 0.32 & $0.62^{1}$ & 0.064 & 2.5 & $5.5^{1}$ & $0.39^{1}$ \\
\hline Max flow, pph & 0.003 & 0.01 & 0.09 & 0.17 & 0.02 & 0.68 & 1.49 & 0.11 \\
\hline $\mathrm{H}_{2}$ Time, hr & 7.9 & $32^{7}$ & $22.5^{6}$ & $23.3^{8}$ & $32^{4}$ & $9^{3}$ & $3.5^{5}$ & $25^{2}$ \\
\hline Max $\mathrm{H}_{2}$ pH & 2.9 & 5.7 & 5.6 & 3.9 & 6.2 & 4.6 & 5.5 & 5.2 \\
\hline Min SRAT pH & 2.6 & 3.6 & 4.2 & 3.7 & 3.6 & 3.1 & 3.7 & 3.3 \\
\hline Final SRAT pH & 4 & 5.7 & 5.8 & 4 & 6.4 & 5.9 & 8.4 & 6.1 \\
\hline Code: HY-91- & 22 & $24^{7}$ & $28^{6}$ & $19^{8}$ & $27^{4}$ & $29^{3}$ & $18^{5}$ & $17^{2}$ \\
\hline
\end{tabular}

1. Denote runs discussed in WSRC-MS-92-109.

2. There was a mini-peak right after acid addition, then there was a double humped peak, with the second hump larger than the first (at 18 and 25 hours).

3. Hydrogen was running about $0.9 \%$ when there was a rapid drop in $\mathrm{pH}$ from about 7.5 to 4.5 . Hydrogen then jumped to $2.5 \%$ over about a two hour period.

4. There was no surge in hydrogen generation when the $\mathrm{pH}$ fell rapidly from about 6.5 to 4 . Eight hours later hydrogen began increasing steadily to about $0.04 \%$, held there for several hours, dipped, then jumped to $0.05 \%$, and a couple hours later spiked briefly at $0.06 \%$.

5. The $\mathrm{pH}$ fell from 11 to 4 at about 1.5 hours, hydrogen appeared at 2 hours, peaked at 3.5 hours, and almost immediately began to fall. At 5 hours the hydrogen was at about $1.5 \%$, and at 10 hours it was at about $0.6 \%$. The $\mathrm{pH}$ rose equally fast and was at 7 at about the fifth hour of the test ( 1.5 hours after the peak $\mathrm{H}_{2}$ ).

6. The Tank 15 waste in this run only (of the runs above) was washed with $\mathrm{NaOH}$ to reduce aluminum content. Hydrogen appeared shortly after the $\mathrm{pH}$ fell from acid addition, but only at about $0.02 \%$. A second drop in $\mathrm{pH}$ occurred after 6-7 hours, and hydrogen generation rate increased more or less steadily over the next 12 hours before it started to fall off.

7. Negligible hydrogen appeared after formic acid addition. After PHA addition and the second drop in $\mathrm{pH}$, the hydrogen generation rate rose continuously for 19 hours to its maximum, then began to slowly fall off.

8. Hydrogen generation went above $0.1 \%$ after formic acid addition and increased during PHA addition, but started to fall before PHA was all added. Near the end of PHA addition the hydrogen generation rate picked up and reached a maximum about three hours after addition ended.

Ha reports (on old presentation slides obtained from D. Ferrara), that results of IDMS HM2 sludge were reproduced inside the Shielded Cells, but results of IDMS Purex sludges were not reproduced inside the Shielded Cells. Graphs of the hydrogen exit flow rate versus time are also available for all of the simulant runs, even though this summary only gives descriptions for the real waste runs.

\subsubsection{Program Two, 1992}

Six more SRAT simulations were performed in 1992 to test the LW/NA flowsheet. All used PHA with about 22,000 ppm formate. The run details are in WSRC-NB-92-138 and WSRC-NB-92-260 (both were in D. M. Ferrara's possession in 2002). These runs were made with $100 \mathrm{~mL}$ of sludge under a $10 \mathrm{sccm}$ argon purge like the 1991 runs above. 
The six runs form three natural pairs. The first pair tested simulated Purex sludge with both the HAN/FA and LW/NA flowsheets, the second pair tested Tank 15 sludge with both the HAN/FA and LW/NA flowsheets, and the third pair tested Tank 11 sludge using the LW/NA flowsheet with either irradiated or unirradiated PHA (technically, the salt simulant from which the PHA was prepared was subjected to irradiation, not the PHA stream itself) The compositions below for Tank 11 and Tank 15 sludges used in 1992 are given in WSRC-RP-92-1137, while the composition for Tanks 4 and 51 are from WSRC-TR-91396:

Table 14 - Sludge Compositions for the Sludges Used in 1992 Tests

\begin{tabular}{|l|c|c|c|c|}
\hline Species & Tank 4 & Tank 51 & Tank 11 & Tank 15 \\
\hline $\mathrm{Fe}$ & 24.3 & 23.1 & 5.3 & 6.2 \\
\hline $\mathrm{Al}$ & 1.8 & 6.4 & 18.3 & 17.2 \\
\hline $\mathrm{Na}$ & 12.4 & 3.4 & 9.7 & 9.0 \\
\hline $\mathrm{Mn}$ & 1.4 & 2.3 & 2.6 & 3.9 \\
\hline $\mathrm{Mg}$ & 0.06 & 0.85 & 0.22 & 0.24 \\
\hline $\mathrm{Ca}$ & 0.64 & 1.7 & 0.27 & 0.45 \\
\hline $\mathrm{Hg}$ & 0.03 & 0.02 & 5.7 & $5.3^{2}$ \\
\hline $\mathrm{U}$ & 6.2 & 2.1 & 0.02 & 0.02 \\
\hline $\mathrm{Th}$ & 0.001 & 0.03 & 0.008 & 1.3 \\
\hline $\mathrm{Ag}$ & $0.002 / 0.002$ & $0.010 / 0.014$ & 0.0013 & 0.003 \\
\hline $\mathrm{Pd}{ }^{1}$ & $0.006 /<0.02$ & $0.0004 /<0.002$ & 0.002 & 0.002 \\
\hline $\mathrm{Rh}^{1}$ & $0.025 / 0.030$ & $0.0008 / 0.002$ & 0.025 & 0.036 \\
\hline $\mathrm{Ru}$ & $0.115 / 0.119$ & $0.005 / 0.002$ & 0.082 & 0.13 \\
\hline $\mathrm{Ni}$ & 5.2 & 0.32 & 1.1 & 0.67 \\
\hline $\mathrm{Cr}$ & 0.12 & 0.14 & 0.16 & 0 \\
\hline $\mathrm{Zn}$ & - & - & 0.35 & 0.34 \\
\hline $\mathrm{Ba}$ & - & - & 0.11 & 0.06 \\
\hline $\mathrm{Soluble} \mathrm{Na}$ & - & - & $0.55 \mathrm{M}$ & $0.44 \mathrm{M}$ \\
\hline $\mathrm{Nitrate}$ & - & - & $0.002 \mathrm{M}$ & $0.004 \mathrm{M}$ \\
\hline
\end{tabular}

1 - When two values are given, the first noble metal result is ICP-MS, and the second is ICP-AES.

2 - There is considerable variation in the mercury results for Tank 15 (1991-1992)

The compositions in Table 14 appear to be fresh analytical results with respect to the results given in Table 11 for the 1991 test sludge compositions for Tanks 11 and 15. No 1992 SRAT tests with Tank 4 or Tank 51 were found, and it may be that this composition data applied originally to the 1991 tests with those two Purex sludges. The Tank 11 and 15 sludges were treated with $4-5 \mathrm{M} \mathrm{NaOH}$ at $80^{\circ} \mathrm{C}$ to dissolve aluminum, and then washed with $0.01 \mathrm{M} \mathrm{NaOH}$. The solids were increased targeting $12 \%$ by settling and decanting (WSRC-RP-92-1137). That was only moderately successful (8.3\% and 17\% instead of $12 \%)$. WSRC-TR-91-396 also has results for Tanks 11 and 15 at 23.6 and 30.8\% aluminum respectively.

Untreated Tank 11 noble metals by the two ICP methods were: 0.0007 wt. \% Ag by ICP-MS $/<0.002$ wt. $\%$ Ag by ICP-AES, 0.005 wt. \% Pd by ICP-MS/ $<0.02$ wt. \% Pd by ICP-AES, 0.022 wt. \% Rh by ICPMS/0.035 wt. \% Rh by ICP-AES, and 0.099 wt. \% Ru by ICP-MS/0.093 wt. \% Ru by ICP-AES. Untreated Tank 15 noble metals by the two ICP methods were: $0.0003 / 0.004$ wt. \% Ag, 0.002/0.15 wt. \% $\mathrm{Pd}, 0.013 / 0.055$ wt. \% Rh, and 0.064/0.077 wt. \% Ru. These results seem consistent with those given in 
Table 14, once an allowance is made for the concentration effect due to the aluminum removal and washing.

Six 1992 runs are detailed in Table 15 below. HAN/FA runs have an $\mathrm{F}$ in the acid row, while LW/NA runs have an $\mathrm{N}$ in the acid row. Both the formic acid and nitric acid were $6 \mathrm{M}$ for the first two pairs. The third pair (Tank 11) tested PHA simulant versus irradiated PHA simulant. Concentrated nitric acid, 16.1M, was used in the two Tank 11 runs. The unirradiated PHA was $0.22 \mathrm{M}$ acid, while the irradiated PHA was $0.31 \mathrm{M}$ acid. Run inputs and results are summarized in Table 15 . The maximum hydrogen flow rate row is at DWPF scale.

Table 15 - Small Scale SRAT Tests of the Late Wash/Nitric Acid Flowsheet

\begin{tabular}{|l|c|c|c|c|c|c|}
\hline Sludge & Purex $^{1}$ & Purex $^{1}$ & Tk 15 & Tk 15 & Tk 11 & Tk 11 \\
\hline Solids, wt. \% & 14 & 14 & 8.3 & 8.3 & 17 & 17 \\
\hline${\mathrm{M}, \mathrm{OH}^{-}}^{-}$ & $?$ & $?$ & $0.05^{6}$ & $0.05^{6}$ & $0.22^{6}$ & $0.22^{6}$ \\
\hline${\mathrm{M}, \mathrm{NO}_{2}^{-}}^{-}$ & $?$ & $?$ & $0.29^{6}$ & $0.29^{6}$ & $0.34^{6}$ & $0.34^{6}$ \\
\hline $\mathrm{Hg}$, wt. \% & $0.5 / 3.8$ & $0.5 / 3.8$ & 2.5 & 2.5 & 4.5 & 4.5 \\
\hline $\mathrm{Ag}$, wt. \% & 0 & 0 & 0.0003 & 0.0003 & 0.0007 & 0.0007 \\
\hline Pd, wt. \% & $0.02 ?$ & $0.02 ?$ & 0.002 & 0.002 & 0.006 & 0.006 \\
\hline Rh, wt. \% & $0.006 ?$ & $0.006 ?$ & 0.013 & 0.013 & 0.03 & 0.03 \\
\hline Ru, wt. \% & $0.03 ?$ & $0.03 ?$ & 0.064 & 0.064 & 0.1 & 0.1 \\
\hline Acid, ml & $2.6-\mathrm{N}$ & $2.6-\mathrm{F}$ & $2.1-\mathrm{F}$ & $2.1-\mathrm{N}$ & $1.1-\mathrm{N}^{5}$ & $2.1-\mathrm{N}^{5}$ \\
\hline $\mathrm{PHA}, \mathrm{ml}$ & 200 & 200 & 200 & 200 & $\sim 195^{4}$ & $152+$ \\
\hline Max H, vol\% & $0.92^{2}$ & $1.6^{3}$ & 0.14 & 0.13 & $<0.01$ & $0.68^{8}$ \\
\hline Max H flow, pph & 0.25 & 0.43 & 0.04 & 0.04 & $<0.003$ & 0.18 \\
\hline $\mathrm{H}_{2}$ Time, hr & 17.5 & 13.5 & 34 & $38^{7}$ & - & 11 \\
\hline Max H2 $\mathrm{HH}_{2}$ & 6.6 & 6.7 & 5.3 & 6.4 & - & 5.7 \\
\hline Min SRAT pH & 5.0 & 6.1 & 4.4 & 5.1 & 4.3 & 4.2 \\
\hline Final SRAT pH & 7.3 & 7.4 & 5.5 & 6.6 & 5.2 & 5.4 \\
\hline Code: HY-92- & 1 & 2 & 3 & 4 & & \\
\hline
\end{tabular}

1. IDMS Purex simulant was doped with $0.0040 \mathrm{~g} \mathrm{NaNO}_{2} / \mathrm{g}$ sludge slurry. Mercury and noble metal composition were reconstructed from recipe data in a lab notebook. Apparently $2400 \mathrm{~g}$ of Purex sludge were trimmed all at once. Conflicting figures were found for $\mathrm{Hg}$.

2. After rising to the maximum, hydrogen dipped to $0.8 \%$, then started to rise again.

3. The peak occurred shortly after PHA addition was complete.

4. This run used the irradiated PHA.

5. Concentrated nitric acid, $16.1 \mathrm{M}$, was used instead of $6 \mathrm{M}$.

6. These numbers could be pre-washed results.

7. Hydrogen rose to a peak of $0.10 \%$ at 21 hours (a few hours after PHA was all in), then fell slightly, and rose later to the maximum reported in Table 15.

8. Hydrogen rose to a sharp peak during PHA addition, and then fell to nearly zero. Hydrogen rose later to about $0.04 \%$ at 20 hours and died off slowly.

9. $\mathrm{F}$ and $\mathrm{N}$ stand for formic and nitric acid in the acid volume row, not for formality and normality.

The time measurement was calculated from when the SRAT vessel was first heated until the peak hydrogen concentration occurred. PHA was added at a rate of $15 \mathrm{ml} /$ hour in the LW/NA runs, and at a rate of $25 \mathrm{~mL} / 10$ minutes in the HAN/FA runs. The hydrogen concentration versus time curves for the 
two Tank 15 runs above were extremely similar. The calculated hydrogen flows agree well with those reported in WSRC-RP-92-1137.

The above results for the six runs raised many questions. The final $\mathrm{pH}$ of both simulant runs suggested that the acid addition wasn't overly generous. Results for nitrite destruction were not found. Hydrogen generation peaked sooner and at a higher concentration in the HAN/FA test than in the LW/NA test. Presumably this was related to the greater availability of formic acid/formate running this flow sheet. Only a minor difference was noted between the two flowsheets using real Tank 15 waste sludge. The significantly higher final $\mathrm{pH}$ of the LW/NA Tank 15 test suggests that there may have been issues of different loadings of the sludge in the two tests, since the acid additions and formate loss to hydrogen were essentially the same in both runs.

Earlier tests with Tank 11 showed that the hydrogen generation was linked to acid quantity. Hydrogen generation could be quite significant. Hydrogen was detected in the test with irradiated PHA, but the maximum reading was only about $0.008 \%$. Perhaps something in the irradiated PHA acted like a catalyst poison. There were some questions in the raw data about exactly how much PHA was eventually added to both Tank 11 tests. Neither run followed the run plan as originally documented.

It appeared from the raw data and lab notebook that the original plan was to add $2.1 \mathrm{~mL}$ of $6 \mathrm{M}$ acid plus $200 \mathrm{~mL}$ of PHA. When only $16.1 \mathrm{M}$ acid was available, the amount was cut to $1.1 \mathrm{ml}$, but this corresponds to $2.95 \mathrm{~mL}$ of $6 \mathrm{M}$. Apparently, $2.1 \mathrm{~mL}$ were added to the second Tank 11 run instead. That volume was the desired amount of $6 \mathrm{M}$, but $16.1 \mathrm{M}$ apparently was used instead. The data for the tail end of both Tank 11 PHA additions are difficult to interpret. It appears PHA was being added either to reach an end point $\mathrm{pH}$, or perhaps was added at a different rate because there was less available than expected.

In WSRC-RP-92-1137, the Tank 15 LW/NA data were compared to the second Tank 15 run in Table 13 above (HAN/FA), rather than to the Tank 15 HAN/FA run done at the time of the study. This choice made the LW/NA flowsheet maximum hydrogen appear to be about three times lower than the HAN/FA flowsheet maximum hydrogen. The other comparison would not have shown this large difference. The comparison of Tank 11 results with unirradiated PHA (last column in Table 15 above, and the middle Tank 11 result from Table 13 above) suggest a similar reduction in maximum hydrogen generation of a factor of about three. The authors were probably in the best position to pick the runs that matched most closely in processing conditions. It is also clear that there were enough factors changing from run to run that making these comparisons between runs was difficult.

The Shielded Cells data alone do not conclusively prove that the Late Wash/Nitric Acid flowsheet led to lower hydrogen production than the HAN/Formic Acid flowsheet. However, if that conclusion was proved elsewhere, e.g. in the controlled study with simulants by Hsu, then the Shielded Cells data here could be taken as a conditional confirmation of a trend. The researchers did not observe an increase in induction period with nitrite concentration or an effect from using Purex versus HM sludge at a given noble metal concentration.

It was not at all clear whether or not mercury was effectively removed in any of the above 24 SRAT tests (no SRAT product $\mathrm{Hg}$ data found). Refluxing was done with a condenser directly back into the SRAT. There was no mercury water wash tank separator, but small amounts of mercury typically attach to parts of the glass condenser surface in such tests. The researchers concluded that the studies did not support mercury acting as a poison. The data support that mercury was not an effective poison, i.e. an eliminator of catalytic activity, but do not establish any degree of intermediate effect on catalytic activity.

Hsu reported in WSRC-RP-92-1236 that two radioactive sludges were treated according to the Nitric Acid/Late Wash flowsheet and produced peak hydrogen evolution rates of 0.038 and $0.20 \mathrm{lb} / \mathrm{hr}$ at DWPF 
scale. These peak rates were a factor of 2.5 and 3.4 lower than for the HAN hydrolysis flowsheets for Tank 15 and Tank 11 respectively. This reference to radioactive sludge data must refer to the 1991-1992 tests above.

\subsubsection{Interim Tests}

There were some mini-SRAT runs made about February-March 1994 reported in WSRC-NB-94-60 (D. M. Ferrara). These runs had less than $100 \mathrm{~mL}$ of sludge $(20-90 \mathrm{ml})$. Some of these runs used an air purge instead of argon. Apparently there also was a large Shielded Cells SRAT run that used 22 liters of Batch 1 sludge in 1995. It used the Late Wash/Nitric Acid flowsheet with PHA. SRAT hydrogen peaked at $0.02 \%$, and SME hydrogen peaked at $0.003 \%$. There was a $50 \mathrm{sccm}$ argon purge, which was raised to $100 \mathrm{sccm}$ at some point late in the run. This run is documented in WSRC-NB-95-24 (D. M. Ferrara). These argon purges are at least a factor of ten below scaled nominal DWPF purge rates. Reports on the work described in this section were not found in the search of WSRC Records.

\subsubsection{Sludge Batch 1A (Macrobatch One)}

The next documented Shielded Cells test was the qualification run for Sludge Batch 1A (SB1A), using the sludge-only flowsheet. This run included both SRAT and SME cycles. It is described in WSRC-TR-950481, Ferrara et al. The run apparently occurred about 11/4/95. The washed Tank 51 noble metal concentrations were reported as $0.014 \mathrm{wt}$. \% Ag, $0.00054 \mathrm{wt}$ \% Pd, $0.00075 \mathrm{wt}$ \% $\mathrm{Rh}$, and $0.0028 \mathrm{wt}$ \% $\mathrm{Ru}$ in the dried solids. The SRAT test used $100 \mathrm{ml}$ of $17 \mathrm{wt}$ \% total solids Tank 51 waste sludge. The purge gas was argon at $10 \mathrm{sccm}$ (same sludge volume and purge as in Ha and Ferrara's work discussed earlier). The purge was $\sim 43 \%$ of a nominal $188 \mathrm{scfm}$ air purge.

After nitric acid addition, $0.24 \mathrm{M}$ formic acid was added slowly to simulate PHA addition. The SRAT pH fell below seven after about 6-7 hours (measured from the start of nitric acid addition). This gives a sense of the rate of formic acid addition. The $\mathrm{pH}$ ultimately fell to between 4.5 and 5.0 and remained there until the SRAT cycle was terminated at 19 hours. A small SRAT hydrogen peak was mentioned in the report with the phrase "never high enough to quantify". WSRC-NB-95-188 seems to contain the appropriate raw data, and a peak of $0.012 \%$ hydrogen was observed which declined slowly during SRAT dilute formic acid addition to about $0.007 \%$, and continued falling to $0.001 \%$ during reflux.

Nitrite ion was barely destroyed (from the standpoint of noble metal activation). The SRAT product slurry contained about $450 \mathrm{ppm}$ nitrite. Hydrogen peaked in the SME cycle at 1.7 vol. $\%$ after about six hours (and both frit additions). The hydrogen concentration exceeded 1\% for about 1.2-1.3 hours. There were simultaneous peaks in carbon dioxide and $\mathrm{N}_{2} \mathrm{O}$. The $\mathrm{pH}$ was about 6.5. There is no indication that this was an effect due to adding acid to simulate a redox adjustment. The observation came without interruption during the SME cycle boil down period. The hydrogen concentration decreased over the next three hours to about $0.2 \mathrm{wt}$. \%. SME product nitrite was still about $250 \mathrm{ppm}$ on a slurry basis. WSRCTR-96-0142 reports the peak hydrogen rates for the SRAT and SME as both $<0.003 \mathrm{lb} / \mathrm{hr}$ at DWPF scale (6000 gallons at $20.5 \mathrm{wt}$. \% solids). The SME cycle discrepancy is hard to resolve.

It seems likely that the low nitrite destruction in the SRAT was related to the spike in hydrogen generation in the SME cycle. The supposed logic would be: the noble metals were not activated effectively in the SRAT cycle, therefore they did not get to deactivate (which only seems to follow activation), then the additional formic acid associated with frit addition triggered further nitrite destruction, and the additional nitrite destruction led to some additional catalyst activation which triggered the hydrogen release. It is possible that the noble metals may interact differently with frit than with sludge, if they are not reduced to their elemental state until the SME cycle. 
A test of formic acid remediation of SME product was made, WSRC-TR-96-0142. Hydrogen generation peaked at $0.16 \mathrm{lb} / \mathrm{hr}$ DWPF scale when the temperature was taken from $90^{\circ} \mathrm{C}$ to $100^{\circ} \mathrm{C}$ (actually boiling). No hydrogen was seen below $80^{\circ} \mathrm{C}$. SME product temperature was ramped up at a rate of $10^{\circ} \mathrm{C}$ every two hours until boiling. Again, this appears to be a separate observation from the 1.7 vol. $\%$ observed above during the SME boil down.

Another Shielded Cells run may have been made about 12/95, using either Tank 51 or a Tank 42/Tank 51 sludge blend. This run is referenced in WSRC-NB-95-373 (D. M. Ferrara). It used a $10 \mathrm{sccm}$ air purge. No hydrogen was seen. The run data do not seem to be readily accessible elsewhere. Some information was found in SRT-GTC-96-0042. The hydrogen generation rate was calculated to be $0.0006 \%$ of the DWPF hydrogen design basis flow rate. This compares to $0.0004 \%$ for the Tank 51 run with argon above.

\subsubsection{Sludge Batch 1B (Macrobatch Two)}

The next Shielded Cells test was the confirmation run of the sludge-only flowsheet with Tank 42 radioactive sludge. The SRAT cycle was documented in WSRC-RP-98-00329 (Fellinger et al.). Approximately $350 \mathrm{ml}$ of Tank 42 sludge at $16.0 \mathrm{wt}$. \% solids was used per WSRC-RP-98-00406 (Hay and Bibler). The acid basis was originally $125 \%$ of the calculated stoichiometric requirement, but this was increased to $137.5 \%$ at the request of DWPF Engineering. $12.4 \mathrm{ml}$ of nitric acid and $9.2 \mathrm{ml}$ of formic acid were added. This appears to be a fairly oxidizing ratio of the two acids. The SRAT was refluxed for 12 hours.

The maximum hydrogen generation rate was $0.0035 \mathrm{lb} / \mathrm{hr}$ on a DWPF basis, and the peak concentration was $0.0057 \%$ on a nominal purge DWPF basis. This peak occurred about two hours into reflux. The hydrogen generation rate held fairly steady at roughly $2 / 3$ the maximum rate for the remainder of the reflux period, i.e. significant noble metal deactivation with processing time was not evident. The carbon dioxide generation rate, however, fell steadily during this period, though it was always at least 10x the hydrogen generation rate. SRAT nitrite destruction was from $7240 \mathrm{mg} / \mathrm{L}$ to $<570 \mathrm{mg} / \mathrm{L}(<1 \mathrm{mg} / \mathrm{L}$ in a $1 / 570$ dilution). (Tracking nitrite ion below $100 \mathrm{mg} / \mathrm{L}$ has been a sample dose issue for Shielded Cells testing. Work with simulants has suggested that nitrite destruction, as it relates to full noble metal activation, may require nitrite concentrations of $<10 \mathrm{mg} / \mathrm{L}$.)

A SME cycle was performed following the SRAT cycle. The test was documented in WSRC-RP-9800351 (Fellinger et al.). DWPF-scale hydrogen generation peaked at $0.0029 \mathrm{lb} / \mathrm{hr}$. It was preceded by an $\mathrm{N}_{2} \mathrm{O}$ release, probably attributable to undestroyed nitrite ion left over from the SRAT cycle. (Simulant nitrite ion destruction seems to have occurred faster and at a lower excess acid stoichiometry than radioactive waste nitrite ion destruction.)

\subsubsection{Sludge Batch 2 (Macrobatch Three)}

A Shielded Cells confirmation test based on a sample from Tank 40 was performed. Tank 40 blended with the contents of Tank 8 became Sludge Batch 2 (SB2). Preliminary results are documented in WSRC-RP-2001-00971, Fellinger et al. Final SRAT cycle results are documented in WSRC-TR-200200076. Final SME cycle results are documented in WSRC-TR-2002-00096. The SB2 noble metal content is compared to other work in Table 16: 
Table 16 - Noble Metals in Macrobatch Confirmation Tests

\begin{tabular}{|l|c|l|l|l|l|}
\hline Metal & PUREX & HM & SB1A & $\begin{array}{c}\text { SB1B (1/98 } \\
\text { sample) }\end{array}$ & $\begin{array}{c}\text { SB2 partial } \\
\text { wash }\end{array}$ \\
\hline Ag, wt. \% & 0.014 & 0.014 & 0.032 & 0.036 & 0.0106 \\
\hline Pd, wt. \% & 0.026 & 0.079 & 0.00063 & 0.0021 & 0.000885 \\
\hline Rh, wt. \% & 0.008 & 0.038 & 0.00089 & 0.0051 & 0.00777 \\
\hline Ru, wt. \% & 0.028 & 0.217 & 0.0024 & 0.021 & 0.0332 \\
\hline
\end{tabular}

HM and PUREX noble metals were taken from a late IDMS run summary table (see IDMS discussion in section 2.5). SB1A and SB1B results were taken from the SRAT confirmation run reports cited above. Rhodium in SB2 is higher than either previous sludge batch as is ruthenium.

Hydrogen generation results for Sludge Batches 1A-2 are summarized in below in Table 17.

Table 17 - Hydrogen Generation in Sludge Batches 1A-2

\begin{tabular}{|c|c|c|c|}
\hline Batch & $\begin{array}{c}\text { SRAT } \mathrm{H}_{2}, \\
\mathrm{lbs} / \mathrm{hr}\end{array}$ & $\begin{array}{c}\text { SME H} \\
\mathrm{lbs} / \mathrm{hr}\end{array}$ & $\begin{array}{c}\text { \%Acid } \\
\text { Stoichiometry }\end{array}$ \\
\hline 1A & $<0.003$ & $<0.003$ & not reported \\
\hline 1B & 0.0035 & 0.0029 & 137.5 \\
\hline 2 & 0.00076 & 0.003 & 125 \\
\hline
\end{tabular}

The low SRAT hydrogen generation rate in SB2 may be linked to the relatively mild and late nitrite ion destruction produced by the $125 \%$ acid stoichiometry recommended by the simulant tests (tests described in section 2.7.6). This was also observed in some work with SB1A. The SRAT air purge was also only 0.125 prototypical during the Shielded Cells testing. The significantly lower oxygen availability may have impacted certain chemical processes related to gas generation. Operating at close to the minimum acid stoichiometry for minimum acceptable nitrite ion destruction seems to correlate with lower hydrogen generation rates.

\subsubsection{Commentary on Shielded Cells Testing}

Sludge batch qualification testing has been performed at acid stoichiometries that were predicted to be safely below the DWPF design basis hydrogen limit using data from simulant tests. This has been successful so far. The results are not particularly useful in understanding hydrogen generation, however, since avoiding excessive hydrogen generation was the goal. Specifically, this testing does not help to identify the most active noble metal, it does not help to clarify the relationship between excess acid and peak hydrogen generation, it does not help to clarify the roles of mercury, nitrite, or silver (and their interactions with the noble metals) on hydrogen generation. This testing, however, does help to define the region where excessive hydrogen generation is not an issue. The main accomplishment has been the validation of the simulant test screening process as a predecessor to the single Shielded Cells qualification run.

Table 13 and Table 15 provide examples of radioactive slurries that produced significant quantities of hydrogen. In some cases this exceeded the DWPF design basis for hydrogen in the SRAT cycle. Apparently, all that is required is a modest quantity of noble metals and enough total acid (including some formic acid) to produce hydrogen at or above the design basis limit. This emphasizes the importance of both the Shielded Cells qualification process and of the supporting simulant tests that help to define the acid addition level that is likely to lead to excessive hydrogen generation. The SRNL hydrogen 
generation program also seeks to define the acid addition level that is likely to lead to excessive hydrogen generation in more general (less sludge batch specific) terms.

\subsection{Sludge Batch Supporting Simulant Studies}

The next section discusses simulant tests in support of DWPF Sludge Batches 1A, 1B, and 2. These include flowsheet studies directly supporting the Shielded Cells tests. These also include side issue studies using the same simulants. Examples are tests for an increased SRAT batch volume, tests linked to the Salt Alternatives program, tests related to development of improved antifoam agents, etc.

\subsubsection{Sludge Batch 1A}

WSRC-RP-97-40, Rev. 1, by Lambert et al., covers the alternative Tank 51 sludge-only process development tests for DWPF. The "alternative" was switching from the addition of a dilute formic acidcopper solution to the addition of copper-free, concentrated formic acid in the SRAT. Tests used $\sim 17 \mathrm{wt}$. $\%$ total solids Tank 51 simulant. Thirteen scoping runs were made. These were eight hour long SRAT simulations with various acid stoichiometries. Six runs had added copper and seven runs added no copper.

These runs were followed by four variability study runs (three were planned but one was repeated due to problems with frit batching). The variability study runs were at 1) nominal conditions (125\% acid), 2) acid under-addition (100\%), and 3) formic acid over-batching (500 gallons DWPF scale formic acid added). The bench-scale runs were followed by two runs of the 1:200 SRAT. These made melter feed for the 774-A research melter. The first run was with the then current flowsheet, the second with the alternative flowsheet.

Noble metal concentrations for the tests, as wt. \% in dried sludge, were slightly higher than the Tank 51 values per Table 18 .

Table 18 - Mercury and Noble Metals in Tank 51 Tests

\begin{tabular}{|l|c|c|c|c|}
\hline Element & $\begin{array}{c}\text { Target for } \\
\text { tests }\end{array}$ & Tank 51 & Purex Basis & HM Basis \\
\hline $\mathrm{Hg}$ & 0.192 & 0.15 & 0.102 & 3.263 \\
\hline $\mathrm{Ag}$ & & & 0.014 & 0.014 \\
\hline $\mathrm{Pd}$ & 0.000584 & 0.00051 & 0.026 & 0.079 \\
\hline $\mathrm{Rh}$ & 0.00111 & 0.00069 & 0.008 & 0.038 \\
\hline $\mathrm{Ru}$ & 0.00713 & 0.00260 & 0.028 & 0.217 \\
\hline
\end{tabular}

Even the target values for $\mathrm{Pd}, \mathrm{Rh}$, and $\mathrm{Ru}$ were far below the Purex basis and HM basis concentrations in section 2.5.

Hydrogen generation rates were found to be higher for runs with copper than without copper at the same acid stoichiometry. This finding must be taken in the context of low noble metal concentrations. Maximum generation rates in the scoping tests were $0.0019-0.0052 \mathrm{lb} / \mathrm{hr}$ at DWPF scale at the nominal $125 \%$ acid (both runs had copper). Concentrations at the Formic Acid Vent Condenser (FAVC) outlet were $0.006-0.014 \%$ (two identical runs). The DWPF limit for the SRAT had been set at $0.65 \mathrm{lb} / \mathrm{hr}$ hydrogen. These runs were only at boiling for about five hours. The maximum possible hydrogen 
generation rate was not necessarily reached. This was especially true of low acid runs where nitrite destruction was very slow.

The bench-scale variability studies continued for a longer period of time. The nominal Tank 51 maximum hydrogen generation rate was $0.006 \mathrm{lb} / \mathrm{hr}(0.04 \mathrm{vol} . \%)$. It came at about 16 hours after the initiation of boiling following acid addition. Generation rates reached $0.036 \mathrm{lb} / \mathrm{hr}$ in the maximum formic acid test $(0.23$ vol. \%). A reduction in maximum hydrogen generation rate for the alternative flowsheet was also observed in the 1:200 SRAT. Generation rates with the dilute formic acid/copper flowsheet reached $0.0016 \mathrm{lb} / \mathrm{hr}$, while rates with the alternative flowsheet only reached $0.0006 \mathrm{lb} / \mathrm{hr}$.

\subsubsection{Sludge Batch 1B}

WSRC-RP-98-00149, Rev. 1 by D. P. Lambert and C. S. Boley, covers Tank 42 sludge-only process development for DWPF (Sludge Batch 1B or Macrobatch 2). Six bench-scale runs were conducted with Tank 42 (not Macrobatch 2, but Tank 42 before transfer to Tank 51) simulant. Tank 42 simulants in all simulant work that follows were prepared by trimming Tank 51 Optima simulant left over from cold runs. Trimming was originally based on WSRC-RP-98-00406. Later trimming supplemented that report with information obtained from actual processing of Sludge Batch 1B in DWPF. Five runs used "110\% of Tank 42 noble metals". One run used "HM levels of noble metals". Table 19 below gives actual levels along with the Purex and HM basis levels:

Table 19 - Tank 42 Sludge-Only Process Development Noble Metals

\begin{tabular}{|l|l|l|l|l|}
\hline Element & $\begin{array}{c}110 \% \text { Tank } \\
42\end{array}$ & $\begin{array}{c}\text { HM for } \\
\text { Tank 42 }\end{array}$ & Purex Basis & HM Basis \\
\hline $\mathrm{Hg}$ & $0.99 \%$ & $3.263 \%$ & $0.0036 \%$ & $1.166 \%$ \\
\hline $\mathrm{Ag}$ & $0.016 \%$ & $0.0014 \%$ & $0.014 \%$ & $0.014 \%$ \\
\hline $\mathrm{Pd}$ & $0.0014 \%$ & $0.079 \%$ & $0.026 \%$ & $0.079 \%$ \\
\hline $\mathrm{Rh}$ & $0.0048 \%$ & $0.028 \%$ & $0.008 \%$ & $0.038 \%$ \\
\hline $\mathrm{Ru}$ & $0.020 \%$ & $0.217 \%$ & $0.028 \%$ & $0.217 \%$ \\
\hline
\end{tabular}

The $0.0014 \%$ HM silver concentration is probably a typographical error in the table in WSRC-RP-9600149. The $0.028 \%$ Rh comes from a typo on "Table 6. IDMS Run Summary", copies of which can be found in various files in SRNL. The HM basis for mercury went up to $3.263 \%$ from $1.166 \%$. A precise date for this was not found, but it was probably before 1997. (See IDMS discussion in section 2.5.)

Four tests were at $125 \%$ acid, including the run with HM levels of noble metals and mercury. One test was at $137.5 \%$ acid and one at $254 \%$ (simulated formic acid tank dump). Run 1V used more nitric acid and less formic acid than run $2 \mathrm{~V}$. Runs $5 \mathrm{~V}$ and $6 \mathrm{~V}$ were similar to Run $2 \mathrm{~V}$. Run $6 \mathrm{~V}$ was supposed to reproduce run $2 \mathrm{~V}$. Run $5 \mathrm{~V}$ was run at $137.5 \%$ acid to improve nitrite destruction which was only fair in $2 \mathrm{~V}$.

Only the maximum volume \% hydrogen overall was reported. This occurred during the SME cycle except in run $4 \mathrm{~V}$ as seen in Table 20. 
Table 20 - Tank 42 Simulant Bench-Scale Hydrogen Generation Data

\begin{tabular}{|l|c|c|c|c|c|c|}
\hline Run & $\begin{array}{l}\text { Noble } \\
\text { Metals }\end{array}$ & $\begin{array}{l}\text { Acid, \% } \\
\text { Stoichiom. }\end{array}$ & $\begin{array}{l}\text { SRAT H } \\
\text { max vol \% }\end{array}$ & $\begin{array}{l}\text { Max SRAT } \\
\mathrm{H}_{2}, \mathrm{lb} . / \mathrm{hr}\end{array}$ & $\begin{array}{l}\text { SME } \mathrm{H}_{2}, \\
\text { max vol \% }\end{array}$ & $\begin{array}{l}\text { Max SME } \\
\mathrm{H}_{2}, \mathrm{lb} . / \mathrm{hr}\end{array}$ \\
\hline 1V & 42 & 125 & & 0.010 & 0.158 & 0.059 \\
\hline 2V & 42 & 125 & & 0.001 & 0.001 & 0.000 \\
\hline 3V & $\mathrm{HM}$ & 125 & & 0.104 & 0.368 & 0.167 \\
\hline 4V & 42 & 254 & 0.443 & 0.310 & & 0.162 \\
\hline $5 \mathrm{~V}$ & 42 & 137.5 & & 0.004 & 0.005 & $0.085^{1}$ \\
\hline $6 \mathrm{~V}$ & 42 & 125 & & 0.001 & 0.001 & $0.012^{1}$ \\
\hline
\end{tabular}

1 - These numbers do not seem consistent (too high) with the maximum volume percentages based on the numbers reported for runs $1 \mathrm{~V}$ $4 \mathrm{~V}$.

SRAT maximum hydrogen generation occurred in the formic acid dump test, Run $4 \mathrm{~V}$, at $0.31 \mathrm{lb} / \mathrm{hr}$. The maximum hydrogen generation in the HM level SRAT test, 3V, (at $125 \%$ acid) was $0.104 \mathrm{lb} / \mathrm{hr}$. The SME maximum in that test was $0.167 \mathrm{lb} / \mathrm{hr}$. The maximum SRAT hydrogen generation rate in other four tests was $0.010 \mathrm{lb} / \mathrm{hr}$. The corresponding maximum SME hydrogen generation rate in these four tests was $0.085 \mathrm{lb} / \mathrm{hr}$. The SME maximum occurred in the run at $137.5 \%$ acid. SRAT product nitrite ion concentration exceeded $1000 \mathrm{mg} / \mathrm{L}$ in runs $1 \mathrm{~V}, 2 \mathrm{~V}$, and $6 \mathrm{~V}$. Consequently, Tank 42 processing following this study was conducted primarily at $137.5 \%$ acid instead of $125 \%$ acid stoichiometry.

There was no spike in hydrogen generation shortly after SRAT acid addition, except for the formic acid dump test. Notably, there was no spike in hydrogen generation in the HM noble metal test. The onset of hydrogen generation in the HM test was delayed to about 13 hours into boiling, and the profile resembled a ruthenium hydrogen generation (long induction period, builds to a peak, then dies off very slowly) from C. W. Hsu's tests, section 2.3. The catalyst in the formic acid tank dump test also was not deactivating rapidly. Hydrogen was still at $\sim 50 \%$ of the maximum generation rate after twelve hours of boiling. Nitrite destruction was slow except for the formic acid dump. Nitrite was above $1000 \mathrm{mg} / \mathrm{liter}$ in two or three of the six SRAT samples after 12 hours of boiling.

\subsubsection{Lambert and Boley - unpublished}

WSRC-NB-97-260, along with a three ring binder full of run data, details a series of tests conducted with 0.5-L quantities of sludge trimmed with $\mathrm{Rh}\left(\mathrm{NO}_{3}\right)_{3}$ solution and $\mathrm{NaNO}_{2}$. The rhodium level was held constant for six tests. The sodium nitrite trim was varied. The sludge was a nitrite-free Purex simulant. The tests were air-purged. The acid addition was not prototypical. All acid was added cold, and then the vessel was brought to boiling. Gas flow and composition were measured. GC data are available for these runs. Manually logged data sheets are available for these runs. The data have not been analyzed or reported. There appear to have been two additional simulations using 5\% Rh on an alumina support (two nitrite levels). There also appears to have been one additional simulation using $\mathrm{RuCl}_{3}$ plus one level of sodium nitrite (a small vol. \% of hydrogen was detected, $\sim 0.007 \%$ ).

\subsubsection{WSRC-TR-99-00111}

This is W.E. Daniel's study on increased CPC batch sizes. Testing was conducted with Tank 42 simulant sludge. This work is unusual in the sense that extra time was taken to produce SRAT product for use as a SRAT heel in the four tests. Testing used the sludge-only REDOX adjusted flowsheet. Runs were coded in a manner similar to the previous study (unfortunately complicating comparisons). Details follow in Table 21 and Table 22: 
Table 21 - Large Batch Run Summary at DWPF Scale

\begin{tabular}{|l|c|c|c|c|c|}
\hline Run & $\begin{array}{c}\text { Sludge wt. } \\
\% \text { total } \\
\text { solids }\end{array}$ & $\begin{array}{c}\text { Sludge, } \\
\text { DWPF } \\
\text { scale }\end{array}$ & $\begin{array}{c}\text { Heel, } \\
\text { DWPF } \\
\text { scale }\end{array}$ & $\begin{array}{c}\text { Additional } \\
\text { Sludge after } \\
\text { Concentration }\end{array}$ & $\begin{array}{c}\text { Acid } \\
\text { Requirement } \\
\% \text { Stoich. }\end{array}$ \\
\hline 1V & 22 & $6000 \mathrm{gal}$ & $1500 \mathrm{gal}$ & $1000 \mathrm{gal}$ & 170 \\
\hline $2 \mathrm{~V}$ & 20 & $6000 \mathrm{gal}$ & $1500 \mathrm{gal}$ & $1000 \mathrm{gal}$ & 137.5 \\
\hline $3 \mathrm{~V}$ & 20 & $6000 \mathrm{gal}$ & $1200 \mathrm{gal}$ & $1000 \mathrm{gal}$ & 300 \\
\hline $4 \mathrm{~V}$ & 22 & $6000 \mathrm{gal}$ & $1200 \mathrm{gal}$ & $1000 \mathrm{gal}$ & 150 \\
\hline
\end{tabular}

The SRAT heel was prepared from Optima Tank 51 simulant trimmed to Purex levels of noble metals and mercury. It was refluxed until the mercury content was $0.45 \mathrm{wt} . \%$. The SRAT feed sludge contained $\sim$ Tank 42 levels of mercury and noble metals, $0.04 \% \mathrm{Ag}, 1.14 \% \mathrm{Hg}, 0.01 \% \mathrm{Pd}, 0.01 \% \mathrm{Rh}$, and $0.02 \% \mathrm{Ru}$ (wt. \% in dried sludge). Run $2 \mathrm{~V}$ occurred first. Nitrite destruction was not completed until the SME cycle. Hydrogen was not detected. Acid was increased for the remaining runs. The following results were obtained (flow rates have been calculated at DWPF-scale):

Table 22 - SRAT/SME Hydrogen Generation Rates for Tank 42

\begin{tabular}{|l|l|c|c|c|}
\hline Run & SRAT $_{2}$ & $\mathrm{SRAT} \mathrm{H}_{2}, \mathrm{lb} . / \mathrm{hr}$ & $\mathrm{SME} \mathrm{H}_{2}$ & $\mathrm{SME} \mathrm{H}_{2}, \mathrm{lb} . / \mathrm{hr}$ \\
\hline $1 \mathrm{~V}$ & $0.023 \%$ & 0.015 & $0.125 \%$ & 0.028 \\
\hline $3 \mathrm{~V}$ & $0.591 \%$ & 0.38 & $1.117 \%$ & 0.25 \\
\hline $4 \mathrm{~V}$ & $0.002 \%$ & 0.001 & $0.026 \%$ & 0.006 \\
\hline
\end{tabular}

The $3 \mathrm{~V}$ numbers compare well with the Tank 42 sludge simulant $254 \%$ acid run ("4V") in Boley and Lambert above. There was a sharp peak superimposed on a broad peak in the hydrogen generation profile for $3 \mathrm{~V}$ however. The sharp peak came first, but before it could die out, a second, more enduring hydrogen generation peak came that persisted throughout the SRAT cycle. Nitrite ion was essentially annihilated before either peak. Hydrogen generation was high and fell only slowly with time during the SME cycle.

\subsubsection{Preparation of Melter Feed Containing CST}

There are three reports dealing with hydrogen generation during the preparation of melter feeds containing CST (crystalline silicotitanate sorbent). They are included here because each study included a blank, or run with no CST, i.e. a conventional simulant melter feed preparation. The first (LambertMonson) study made four CPC process simulations using Tank 42 sludge simulant. Three runs used three different sizes of untreated CST blended with sludge. All four runs used HM levels of mercury and noble metals and $125 \%$ acid stoichiometry. These were 2-liter simulations with nominal, scaled DWPF SRAT and SME air purges.

The run without CST would seem to be a repeat of run 3V in the Lambert-Boley study, WSRC-RP-9800149. There was a spike in hydrogen at the onset of boiling in both the SRAT and SME cycle. Vol. \% and DWPF equivalent $\mathrm{lb} / \mathrm{hr}$ were calculated at the spike and away from the spike for both SRAT and SME. 
Table 23 - SRAT/SME Simulations for the CST Salt Alternative

\begin{tabular}{|l|c|c|c|c|}
\hline Run (no CST) & SRAT H $_{2}$ & SRAT H $_{2}, \mathrm{lb} / \mathrm{hr}$ & $\mathrm{SME} \mathrm{H}_{2}$ & $\mathrm{SME} \mathrm{H}_{2}, \mathrm{lb} / \mathrm{hr}$ \\
\hline spike & $0.194 \%$ & 0.125 & $0.773 \%$ & 0.200 \\
\hline no spike & $0.194 \%$ & 0.125 & $0.542 \%$ & 0.128 \\
\hline 3V-Boley & - & 0.104 & $0.368 \%$ & 0.167 \\
\hline
\end{tabular}

This test and the 3V-Boley test were within $20 \%$, which is fair reproducibility. Rates were markedly higher with CST present in the SRAT (more than doubled in one case). Rates were somewhat higher (10$15 \%$ ) with CST present during the SME cycle.

A year later there were another series of 2-liter simulations, WSRC-TR-99-00277. The runs targeted $137.5 \%$ acid but ultimately ended up being at $150 \%$ acid stoichiometry. The 1999 CST had been caustic washed and loaded with noble metals, whereas the CST in 1998 was untreated. Two sizes of CST were tested against a blank run with no CST. Tank 42 sludge simulant was used. Mercury was at Tank 42 levels. Noble metals were at 110\% Tank 42 levels. At about the same time there were some runs of the $1 / 240^{\text {th }}$ scale Glass Feed Preparation System (GFPS) studying antifoam effectiveness and hydrogen generation, WSRC-TR-99-00302. Both test programs used a Tank 42 sludge simulant similar to Macrobatch 2 (data from DWPF SRAT batches 97-102 combined with Tank 42 decant sample analysis). There were two blank runs and two runs with CST sorbent. The CST sorbent runs had two different sizes of CST particles. The 1999 Tank 42 simulants were the same in the bench-scale work and the GFPS, but there were some small differences with the Tank 42 simulant used in the Lambert-Boley study discussed earlier.

Table 24 - Alternative Salt Process Simulations at Baseline Conditions

\begin{tabular}{|l|c|c|c|c|}
\hline Run & SRAT H $_{2}$ & SRAT H $_{2}, \mathrm{lb} . / \mathrm{hr}$ & $\mathrm{SME} \mathrm{H}_{2}$ & $\mathrm{SME} \mathrm{H}_{2}, \mathrm{lb} . / \mathrm{hr}$ \\
\hline No CST & $0.007 \%$ & 0.005 & $0.068 \%$ & 0.016 \\
\hline 5V-Boley & - & 0.004 & $0.005 \%$ & $0.002^{1}$ \\
\hline GFPS & $0.005 \%$ & $<0.004$ & $0.020 \%$ & $<0.011$ \\
\hline
\end{tabular}

1 - this author re-scaled the results in the Lambert-Boley report by hydrogen volume percent using run $1 \mathrm{~V}$ as a basis.

The $5 \mathrm{~V}$ results from Lambert and Boley were at $137.5 \%$ acid stoichiometry. The no CST bench-scale blank was at $150 \%$ acid. Consequently, the higher hydrogen generation rates are not unexpected for the no CST blank compared to $5 \mathrm{~V}$. The GFPS run was at $150 \%$ acid stoichiometry. It does not match $5 \mathrm{~V}$ perfectly, but is reasonably close. \{ The GFPS was charged with 25 gallons of sludge simulant. It used nominal SRAT and SME air purges. A malfunction in one of the MKS gas flow controllers introduced some additional uncertainty into the calculation of the DWPF scale flow rates. If the impact of the malfunction was ignored, then the SRAT and SME GFPS flows would be 0.0034 and $0.0066 \mathrm{lb} / \mathrm{hr}$ respectively (from rev. 0 of the report). $\}$

\subsubsection{Sludge Batch 2}

WSRC-TR-2000-00398 by D. C. Koopman describes $\underline{\text { Sludge } \underline{B} a t c h ~} \underline{2}$ (SB2 or Macrobatch 3) testing. Because of uncertainty as to whether or not Tank 8 would be transferred to Tank 40 in time for Sludge Batch 2, the preliminary testing scope was expanded to include Tank 40 simulant (no Tank 8) and Tank $8 / 40$ blend simulant. Initial noble metal concentration estimates were inaccurate, but conservatively high. Consequently, a considerable amount of hydrogen generation data were obtained at various levels of noble metals between some scoping SRAT tests (6) and the final flowsheet simulations SRAT tests (4). 
Table 25 below summarizes the noble metal and mercury loadings for the Tank 40 tests $(1 \mathrm{~A}, 2 \mathrm{~A}$, and SB2-2) and the Tank 8/40 blend tests (1B through 4B, SB2-1, SB2-3, and SB2-4).

Table 25 - Noble Metals in Sludge Batch 2 Simulant Tests

\begin{tabular}{|c|l|l|l|l|l|l|}
\hline $\begin{array}{c}\text { Run } \\
\text { ID }\end{array}$ & $\begin{array}{c}\text { Ag } \\
\text { wt. \% }\end{array}$ & $\begin{array}{c}\text { Pd } \\
\text { wt. \% }\end{array}$ & $\begin{array}{c}\text { Rh } \\
\text { wt. \% }\end{array}$ & $\begin{array}{c}\text { Ru } \\
\text { wt. \% }\end{array}$ & $\begin{array}{c}\text { Hg } \\
\text { wt. \% }\end{array}$ & $\begin{array}{c}\text { Acid } \\
\text { Stoichiometry }\end{array}$ \\
\hline 1A & 0.320 & 0.241 & 0.0291 & 0.520 & 0.490 & $137.5 \%$ \\
\hline 2A & 0.0131 & 0.0011 & 0.00077 & 0.00232 & 0.491 & $137.5 \%$ \\
\hline 1B & 0.269 & 0.206 & 0.0271 & 0.432 & 0.285 & $137.5 \%$ \\
\hline 2B & 0.127 & 0.0973 & 0.0147 & 0.205 & 0.294 & $137.5 \%$ \\
\hline 3B & 0.127 & 0.0973 & 0.0147 & 0.205 & 0.294 & $125 \%$ \\
\hline 4B & 0.127 & 0.0973 & 0.0147 & 0.205 & 0.294 & $110 \%$ \\
\hline SB2-1 & 0.127 & 0.0973 & 0.0147 & 0.205 & 0.294 & $125 \%$ \\
\hline SB2-2 & 0.0131 & 0.0011 & 0.00077 & 0.00232 & 0.491 & $137.5 \%$ \\
\hline SB2-3 (HM) & 0.0140 & 0.0790 & 0.0280 & 0.217 & 0.294 & $125 \%$ \\
\hline SB2-4 & 0.250 & 0.202 & 0.0297 & 0.424 & 0.294 & $290 \%$ \\
\hline
\end{tabular}

Hydrogen generation results for the Tank 40 SRAT tests are given in Table 26 below. Some Tank 42 simulant test data are included for comparison. Hydrogen generation rates exceeded the DWPF design basis limit of $0.65 \mathrm{lb} / \mathrm{hr}$ in test $1 \mathrm{~A}$ by more than a factor of two. When new analytical results led to a more than ten-fold reduction in noble metals ( $38 \mathrm{x}$ for $\mathrm{Rh}$ ), the hydrogen generation rate issue disappeared for Tank 40 (without Tank 8) sludge simulant. Results for 2A and SB2-2 were more like those given earlier for Tank 42 simulant tests.

Table 26 - Hydrogen Generation for Tank 40 SRAT Tests

\begin{tabular}{|l|c|c|c|}
\hline & $\begin{array}{c}\text { Mass } \mathrm{H}_{2}, \\
\text { lb. }\end{array}$ & $\begin{array}{c}\text { Max. Rate, } \\
\mathrm{H}_{2}, \mathrm{lbs} . / \mathrm{hr}\end{array}$ & $\begin{array}{c}\text { DWPF } \mathrm{H}_{2} \\
\text { Limit, lbs/hr }\end{array}$ \\
\hline 1A & 5.36 & $\mathbf{1 . 6 9}$ & 0.65 \\
\hline 2A & 0.014 & 0.0013 & 0.65 \\
\hline SB2-2 & 0.015 & 0.0018 & 0.65 \\
\hline Tank 42(125\%) & - & 0.001 & 0.65 \\
\hline Tank 42(137.5\%) & - & 0.004 & 0.65 \\
\hline
\end{tabular}

During the simulant work, the best information for Tank 8 noble metal concentrations remained unchanged. Noble metal concentrations were reduced between tests $1 \mathrm{~B}$ and $2 \mathrm{~B}$ because of the revised figures for the Tank 40 portion of the blend. They remained there for the blend tests that followed except for SB2-3 which used the HM noble metal basis (though not the HM mercury basis) given in "Table 6." of the "IDMS run summary" (which, as has been mentioned, contains a typographical error for HM rhodium wt. \%: 0.028 cited, 0.038 actual). Table 27 below summarizes the SRAT hydrogen results for the Tank $8 / 40$ blend simulant tests. The combination of a formic acid tank dump and the high noble metal concentrations produced a peak SRAT hydrogen generation rate that was ten times the DWPF design basis of $0.65 \mathrm{lbs} / \mathrm{hr}$. 
Table 27 - Hydrogen Generation for Blend SRAT Tests

\begin{tabular}{|l|c|c|}
\hline Run (\% acid) & $\begin{array}{c}\text { Mass } \mathrm{H}_{2}, \\
\text { lb. }\end{array}$ & $\begin{array}{c}\text { Max. Rate, } \\
\mathrm{H}_{2}, \mathrm{lb} . / \mathrm{hr}\end{array}$ \\
\hline 1B $(137.5 \%)$ & 3.26 & $\mathbf{1 . 0 4}$ \\
\hline 2B $(137.5 \%)$ & 2.65 & 0.475 \\
\hline 3B $(125 \%)$ & 1.70 & 0.385 \\
\hline 4B $(110 \%)$ & 0.29 & 0.054 \\
\hline SB2-1 (125\%) & 1.95 & 0.355 \\
\hline SB2-3 (125\%) & 1.43 & 0.311 \\
\hline SB2-4 $(290 \%)$ & 34.86 & $\mathbf{6 . 6 7}$ \\
\hline Tank 42(125\%) & - & 0.001 \\
\hline Tank 42(137.5\%) & - & 0.004 \\
\hline
\end{tabular}

Many of the blend tests came close to the DWPF SRAT hydrogen design basis. The $125 \%$ acid tests showed a sharp increase in hydrogen generation following acid addition that rose to a plateau value. Several hours later, following a small $\mathrm{N}_{2} \mathrm{O}$ peak associated with the onset of reflux, there was a second sharp rise in the generation rate above the plateau value, followed by a gradual decline in hydrogen production over the remainder of the boiling period. The sustained activity appears to be typical of ruthenium catalyzed formic acid decomposition, while the rapid increase following acid addition appears to be typical of rhodium catalyzed formic acid decomposition (based on C. W. Hsu's work, section 2.3).

SME cycle data were obtained for the four Sludge Batch 2 variability study runs. Table 28 below summarizes the results.

Table 28 - Macrobatch 3 SME Cycle Hydrogen Generation

\begin{tabular}{|l|c|c|c|c|}
\hline \multicolumn{1}{|c|}{ Run } & SB2-1 & SB2-2 & SB2-3 & SB2-4 \\
\hline Maximum Concentration, vol. \% & 0.682 & 0.0049 & 0.582 & 2.85 \\
\hline Maximum Generation Rate, lb./hr & 0.140 & 0.0010 & 0.122 & $\mathbf{3 . 0 0}$ \\
\hline Total Mass, lb. & 0.659 & 0.0068 & 0.623 & 9.06 \\
\hline
\end{tabular}

The hydrogen generation in SB2-4 continued from the SRAT cycle into the SME cycle at a high level. With the prototypical purge flow reduction, the volume \% hydrogen went up in the SME cycle compared to the end of the SRAT cycle. The two $125 \%$ acid blend tests approached, but did not exceed, the 0.23 $\mathrm{lb} / \mathrm{hr}$ hydrogen DWPF design basis for the SME. Hydrogen generation was a continuation from the end of the SRAT cycle. There was no spike in hydrogen during the SB2-2 SME cycle. Nitrite ion was well destroyed in all four SRAT cycles, so there apparently was no remaining inactive catalyst in the system that could activate during frit addition and produce a SME hydrogen spike.

Many SRAT cycle simulations were run for the Melt Rate Improvement task, both with Sludge Batch 2 sludge and with Sludge Batch 1B sludge simulants. Many of these tests used no noble metals. The tests with noble metals did not use a gas chromatograph, since the acid stoichiometry had previously been demonstrated to not exceed the design basis, which has a considerable margin of safety built into it.

The $1 / 240^{\text {th }}$ Glass Feed Preparation System was run twice with Sludge Batch 2 blend sludge simulant to prepare feed for the Minimelter, SRT-GPD-2001-020. Batching was similar to SB2-1 in the bench-scale tests above, i.e. same acid stoichiometry, same mercury and noble metals, prototypical air purges, etc. GC data have never been critically reviewed, but hydrogen generation rates did not appear to get as high as in the bench-scale work. The reason this might be so is not clear, but may be related to the relatively 
gentle mixing typical of the GFPS runs. Conversely, IDMS runs seemed to be roughly similar to benchscale tests in terms of peak hydrogen generation rates. A second pair of GFPS runs was made with similar hydrogen results to SB2-1, WSRC-TR-2002-00186. (The first set used frit 200 while the second set used frit 320 in the SME cycle.)

\subsubsection{Commentary on Sludge Batch Simulant Tests}

The simulant test programs have provided some insights into hydrogen generation. Tests in SB1A, SB1B, and SB2 work used at least two different acid stoichiometry factors. This allows comparisons between runs within a sludge batch on the amount of hydrogen produced as a function of acid added. It can also provide information on the amount of acid required to take nitrite ion concentration to a low level, which seems to be a prerequisite for significant hydrogen generation. Tests with SB1A and SB1B had relatively low noble metal concentrations, and correspondingly low levels of hydrogen generation. Tests with SB2, as well as future sludge batches, will be at higher noble metal concentrations. These tests had, or are likely to have, more hydrogen generation than SB1A and SB1B for a given quantity of excess acid.

Copper was weakly significant in SB1A relative to the noble metals. The impact of copper at current levels and in the presence of higher noble metal concentrations should be considerably less significant than what was seen in the SB1A tests.

An enhancement in hydrogen generation was seen when CST was added to simulant containing HM levels of noble metals. The effect was not nearly as significant in tests with SB1B concentrations of noble metals. CST may have become the preferred catalyst support for reduced noble metals, and may have somehow provided a more reactive surface than insoluble sludge particles. The potential for this phenomenon should be considered before introducing new solid phases into the SRAT feed. 


\subsection{CONCLUSIONS}

The body of work reviewed above established some consistent points, provided some apparent contradictions, i.e. more data are needed to clarify these, and indicated some areas that are not well understood, i.e. more data are needed to evaluate the significance of these. These three situations are summarized below.

Established Points:

1) Noble metals catalyze the decomposition of formic acid to produce hydrogen.

- $\quad \mathrm{Rh}, \mathrm{Ru}$, and Pd are present in HLW as fission products and are known catalysts for this reaction.

- $\quad \mathrm{Ru}: \mathrm{Rh}: \mathrm{Pd}$ are expected to be present at ratios of about 3.75:1.0:0.52 by fission yield.

- $\quad \mathrm{Ag}$ is present from natural sources.

- $\quad \mathrm{Pt}, \mathrm{Ir}$, Os, and $\mathrm{Au}$ are not ${ }^{235} \mathrm{U}$ fission products, and should not be in SRS waste.

- Negligible hydrogen generation is detected in SRAT runs without noble metals.

2) Elemental copper and nickel are potential additions to the formic acid decomposition catalyst list, but:

- Copper may be irrelevant at the low concentrations seen in sludge only processing today, and may remain of small consequence depending on the final design of the new Salt Waste Processing Facility.

- $\quad$ Nickel is probably not reduced to elemental form during SRAT processing.

3) Silver can interact directly with $\mathrm{Rh}, \mathrm{Ru}$, and $\mathrm{Pd}$.

- Silver alloys with the noble metals seem to have lower activity than systems containing noble metals without silver.

4) Mercury can interact with noble metals.

- $\quad \mathrm{Hg}$ can form amalgams (liquid alloys) with noble metals.

- $\mathrm{Hg}$ apparently impacts the catalytic activity of noble metals.

5) The nitrite ion plays a role in noble metal catalytic activity.

- $\quad$ Delaying nitrite destruction delays the peak hydrogen generation rate.

- $\quad$ Overly delaying nitrite destruction creates the potential for excessive SME cycle hydrogen.

- $\quad$ Lack of nitrite in the feed leads to less hydrogen generation.

6) Hydrogen can be generated over a wide range in $\mathrm{pH}$, perhaps from $\sim 8$ on down.

7) The amount of acid added directly relates to hydrogen generation in the SRAT.

- More total acid gives more total hydrogen.

- Hydrogen is not evolved during nitric acid addition to waste sludge, except from radiolysis.

- More hydrogen is produced when more formic acid is added.

- Additional hydrogen is produced when supplemental additions of nitric acid are made to neutralized sludge containing formate/formic acid.

- Bench-scale simulations of a formic acid tank dump show that the hydrogen generation rate can approach the DWPF design basis for the SRAT, $0.65 \mathrm{lb} / \mathrm{hr}$, with relatively low concentrations of noble metals (Tank 42). 
8) Palladium is the least active of the three noble metals in sludge simulant testing. Palladium was essentially inactive in HM and Purex sludge simulants.

9) Rhodium appears to activate more readily than ruthenium, i.e. Rh begins to produce hydrogen sooner in time than $\mathrm{Ru}$ under identical conditions. $\mathrm{Ru}$ is more active than $\mathrm{Rh}$ in the absence of nitrite.

10) $\mathrm{Rh}$ activity is enhanced by the presence of the iron precipitate.

11) Rh activity is enhanced by the presence of hydrous aluminum oxide.

12) Processes are at work that tend to decrease the activity of the noble metals over time, however one noble metal can become active after another has lost most of its activity.

13) Copper appeared to contribute to hydrogen generation in runs with low levels of noble metals.

14) Hydrogen generation is normally preceded by $\mathrm{N}_{2} \mathrm{O}$ generation in waste sludge tests.

15) Hydrogen generation may be sensitive to experimental scale (equipment selection and operation).

16) Switching to the Nitric Acid/Late Wash flowsheet led to a reduction in hydrogen generation compared to the Formic Acid/HAN flowsheet.

17) Hydrogen and carbon dioxide are the primary products in simple systems. Other products include carbon monoxide and water. CO has only rarely been detected in SRAT cycles at any significant concentration.

18) Formaldehyde and methyl formate are possible catalyst poisons.

19) Increased carbonate content may correlate with longer induction periods for noble metal activation.

20) The complexing agents NTA (nitriloacetic acid) and EDTA (ethylene diamine tetraacetic acid) are catalyst poisons. EDTA may prevent ruthenium precipitation.

21) Shielded Cells tests with real sludges prior to DWPF start-up indicate that hydrogen generation can be much higher (>100 time larger) than what was seen in the first three Shielded Cell qualifications runs for Sludge Batches 1A, 1B, and 2.

22) Flowsheet modifications (HAN/FA to LW/NA to sludge-only with $\mathrm{Cu}$ to sludge-only without $\mathrm{Cu}$ ) appear to have had a net mitigating effect on peak hydrogen generation.

23) SME cycle hydrogen generation depends on SRAT product nitrite, additional frit acid, and hydrogen generation rate at the end of the SRAT cycle in addition to the levels of noble metals.

24) Delaying catalyst activation (extending the induction period) seems to correlate with sustained catalytic activity (extended and slower deactivation).

Apparent contradictions are listed below. In some cases both (all) statements in a group may somehow be true, but the statements may be limited to certain specific instances that do not permit generalization.

1) Mercury is a noble metal catalyst poison. Mercury is a promoter of increased activity. 
2) Rhodium is inactive in the absence of nitrite ion. Rhodium is active with or without nitrite ion.

3) Ruthenium is not active in sludge simulants. Ruthenium is active in sludge simulants. Ruthenium is only active in the absence of nitrite ion.

4) The fission yield gives $\mathrm{Ru}$ to $\mathrm{Rh}$ to $\mathrm{Pd}$ in the ratio of 3.75 to 1.0 to 0.52 . The HM noble metal basis has the ratios as 5.7 to 1.0 to 2.1. The Purex noble metal basis has the ratios as 3.5 to 1.0 to 3.25. Pd is preferentially removed during tank farm operations (precipitation, decanting, and washing) compared to $\mathrm{Rh}$ and $\mathrm{Ru}$. It is typically present below the fission yield relative to $\mathrm{Rh}$.

5) $\mathrm{Rh}$ is a homogeneous catalyst, e.g. in solution or complexed. $\mathrm{Rh}$ is a heterogeneous catalyst, e.g. a solid phase.

6) The relative activity is 1) $\mathrm{Ru}>\mathrm{Pd}>\mathrm{Rh}$ (Bond), 2) $\mathrm{Pd}>\mathrm{Rh}>\mathrm{Ru}$ (Müller), or 3) $\mathrm{Rh}>\mathrm{Ru}>\mathrm{Pd}$ (U. Ga.).

The third list describes some issues for which there are no data available from which to draw any conclusions.

1) The presence of oxygen from air purging may reduce the hydrogen generation rate compared to tests with nitrogen or argon purging. This would apparently be due to the catalytic oxidation of formic acid per the March $1991 \mathrm{U}$. Ga. report. Oxygen depletion is observed during NO production $\left(\mathrm{NO}+1 / 2 \mathrm{O}_{2} \rightarrow \mathrm{NO}_{2}\right.$ ), but only because it is an abrupt and obvious effect. It is harder to track subtle oxygen consumption that occurs over a long period of time (small difference of large numbers). The presence of oxygen may also impact metal ion reduction.

2) The degree of mixing/agitation may affect hydrogen generation rate and total hydrogen produced. It may also affect the dissolved oxygen content of the sludge. Important processes may be occurring whose rates are mass transfer limited (agglomeration of catalyst nanoclusters, transport of formic acid to active sites, poisoning of catalyst sites, etc.).

3) The role of $\mathrm{pH}$, and/or solution potential, on hydrogen generation is not clear. The effect of sludge composition on $\mathrm{pH}$ and solution potential during acid addition is not understood. Half cell reaction potentials indicate that the solution potential must reach a certain range of values before noble-metal catalyzed hydrogen generation is favored. The precise potential is somewhat different for each noble metal.

4) Fully activating $\mathrm{Rh}$ and $\mathrm{Ru}$ in parallel, rather than in series, would seem to be a worst case scenario for hydrogen generation. Some data seem to show two noble metals becoming significantly active close in time, while other data show two noble metals activating at distinctly different times, and still other data seem to show only a single, relatively mild, noble metal activation (although more than one noble metal might be participating).

5) The role of the sludge particles and their surface potentials on noble metal catalysis is not understood. Would changing the sludge particle characteristics effect the morphology (and simultaneously the activity) of reduced noble metal solids formed during reduction?

6) The presence of other anions, e.g. sulfate, chloride, etc., appears to bear on the precise hydrogen generation rate achieved. The magnitude of the effects of these anions at various washed waste levels on hydrogen generation is not understood. A few model system data points suggest that 
WSRC-TR-2002-00034

Revision 0

these may be second-order effects not critical to a first-order understanding of hydrogen generation.

7) The role of silver in promoting the formation of impure noble metal alloys is not understood, but it appears that the alloys are less active than the pure noble metals. 


\subsection{RECOMMENDATIONS/PATH FORWARD}

Two facts are well documented by the cumulative body of past work. Higher noble metal concentrations lead to more hydrogen generation. Larger formic acid additions lead to more hydrogen generation. The issues remaining to be resolved fall into a number of broad groups. These were:

- How the chemical form and quantity of initial $\mathrm{Hg}$ in the sludge impacts the noble metal catalysts?

- How the chemical form and quantity of $\mathrm{Ag}$ affects the noble metal catalysts?

- How does the physical form and quantity of the starting noble metal precipitates in the sludge matrix and/or their reduction products affect hydrogen generation?

- What is the sensitivity of hydrogen generation to the noble metal concentration?

- How does the operation and set up of the bench-scale equipment alter the hydrogen generation results?

- Can a precise correlation between increases in excess acid and increases in hydrogen generation be developed as a function of noble metal concentration?

- What other interactions are there between the final, washed sludge composition and the noble metals, e.g. the roles of nitrite and the other anions, the roles of the other metallic elements, etc. on hydrogen generation.

- How does the heel affect the activity of the noble metals and the fraction of the acid addition that is present in excess (available for hydrogen generation).

Proposals for investigating some of these issues are given below. The ordering of the proposals is such that the ones given first could help to reduce the experimentation required by some of the later proposals. Several of the later proposals are significant projects in their own right, but ideally would not be started until one or more of the earlier proposals had been completed. Most proposals require new experimental work, some require modeling, and some require statistical data analysis.

\section{Exploit Flowsheet Tests for Future Sludge Batches}

Each sludge batch has a different composition, and the flowsheet studies provide a growing database on the effects of changing sludge composition on hydrogen generation. Hydrogen generation data should continue to be gathered during flowsheet simulations for future sludge batches. This data should be used to establish a database of hydrogen generation rates under various processing conditions. Such data could be used to bound new problems that fall within the range of variables covered by the database. (Since this report was first drafted, a considerable body of new data has been obtained for the SB2/3 system. This data should be reviewed and incorporated into this database.) Hydrogen generation data collected from the three years 2002-2004 are being reviewed during the second phase of the hydrogen generation program, and the findings will be included in that report.

\section{Look for Opportunities to Collect Hydrogen Data}

Opportunities periodically present themselves for obtaining data on hydrogen generation in the SRAT and/or SME cycles. For example, some hydrogen generation data were obtained during the study of the impact of the Actinide Removal Process on SRAT processing. An opportunity arose when the team investigating melt rate as a function of whether alkali came from sludge or frit performed SRAT simulations at previously untested conditions. Another opportunity to perform some scoping tests on the effect of mercury arose in late FY04, since mercury was a potential issue for the upcoming studies for the Sludge Batch 4 flowsheet. These tests became the first phase of the experimental program to better understand hydrogen generation. Data from the Actinide Removal Process work and the source of alkali 
work will be reviewed, and the findings will be included in the report summarizing the second phase of the hydrogen generation program. Appropriate resources should be kept available to bring new hydrogen generation information into any database created to support future hydrogen generation studies.

\section{Test the Significance of Trimmed versus Co-Precipitated Noble Metals}

Simulant testing sets bounds on the acid addition window for the Shielded Cells qualification run and DWPF processing. The use of noble metal trim chemicals may be overly conservative from a hydrogen generation standpoint. This conservatism potentially constrains the reported size of the acid window to be unduly small. The real waste noble metals were co-precipitated with the bulk of the insoluble solids. Consequently, they could be significantly more difficult to dissolve, reduce, and/or activate than the trimmed form used in simulant studies.

To test this concept, it was proposed that two identical simulants be prepared. One of the two would have the noble metals co-precipitated with the bulk of the insoluble sludge species, while the other would be made with no noble metals. Analytical and recipe information would be used to bound the concentrations of the noble metals in the co-precipitated simulant. A portion of each simulant would be heat-treated to simulate aging in the Tank Farm. A series of SRAT cycles would be made on the original and heattreated simulants to assess the impact of using trimmed noble metals added to the simulant without noble metals compared to co-precipitated noble metals. This experimental task has become the second phase of the SRNL program to better understand hydrogen generation.

\section{Test for Other Factors Influencing Hydrogen Generation}

A set of small-scale SRAT simulations can be conducted to examine the following issues experimentally:

1) Silver and its effect on peak hydrogen generation.

2) Nitrite and its effect on induction times and peak hydrogen generation rates.

3) Significance of changing individual inputs to the stoichiometric acid calculation, e.g. hydroxide and carbonate.

4) Significance of other anions, e.g. chloride, sulfate, nitrate, on peak hydrogen generation rate.

One area of concern for DWPF is the impact of new streams on the acid addition window. New canyon and salt waste streams are typically caustic. They may contain nitrite, nitrate, carbonate, and other anions such as chloride, oxalate, and sulfate. A significant increase to an input to the acid addition equation, e.g. nitrite, caustic, or carbonate, triggers an increased stoichiometric acid requirement. This is expected to increase the quantity of excess acid in the SRAT if the stoichiometric factor is held constant. A strategy for off-setting the impact of new streams by adjusting the stoichiometric factor is a possible strategy for adapting to changing feed compositions without repeating the full range of flowsheet simulations associated with a new sludge batch.

\section{Analyze the Lambert-Boley Data}

The raw data in WSRC-NB-97-240 could be analyzed to see what it says about the effect of nitrite on rhodium activity and induction time. The advantage to doing this is that the experiments have already been run, so the cost would be limited to analysis time. A decision has been made to include a review of this data in the report summarizing the second phase of the hydrogen generation program in 2005 . 


\section{Investigate Heterogeneous versus Homogeneous Catalysis}

This is another issue related to the how the form of the noble metals may impact peak hydrogen generation rates. The issue of heterogeneous versus homogeneous catalysis may be resolvable by stopping the SRAT in mid-hydrogen generation, filtering the solids from the supernate, and resuming the SRAT cycle with just the supernate. The rate of hydrogen generation following resumption of the SRAT cycle without solids would be an indicator of the extent of heterogeneous vs. homogeneous catalysis. The test would require some deviation from the routine SRAT cycle. If test conditions match one of the tests done in another phase, then data from the runs can be compared up until the time that the SRAT contents are filtered.

\section{Rank the Relative Significance of the Three Noble Metals}

This task also relates to the noble metal issue in the list at the beginning of the section. The formic acid flowsheet SRAT simulation work of C. W. Hsu showed that either rhodium or ruthenium alone can produce significant hydrogen without the other noble metals present, but that palladium alone does not lead to significant hydrogen generation. These tests were under an inert atmosphere. The tests showed that rhodium activated first, while ruthenium activated after several hours at reflux. A new set of experiments is proposed to confirm that the above results are generally valid and not affected by an air purge. The main objective of the experimental work will be to test for noble metal pair affects. A full factorial design for three factors ( $\mathrm{Pd}, \mathrm{Rh}$, and $\mathrm{Ru}$ concentration) at two levels would require eight experiments. This can be reduced to four SRAT simulations by setting one of the levels to zero and making assumptions based on the previous experimental work.

The following hypotheses are of interest:

- Rh is most active, and is not enhanced by the other two noble metals.

- Rh-catalyzed hydrogen peaks early, while Ru-catalyzed hydrogen peaks late.

- The Rh-Pd system and the Ru-Pd system added together look like the Rh-Ru system.

- Palladium does not enhance/inhibit hydrogen generation from $\mathrm{Rh}$ and $\mathrm{Ru}$

Establishing that one noble metal is critical to hydrogen generation would allow experimental programs to de-emphasize the roles of the other two. This includes preparing co-precipitated noble metal simulants. It would be simpler to co-precipitate one key noble metal and track its concentration, than to try to work with two or three simultaneously.

\section{Develop a Dynamic Model for SRAT Off-Gas Equipment}

Various configurations of equipment have been used since C. W. Hsu's early work to perform SRAT/SME simulations. A check should be made on the significance of the parallel process dynamic effects occurring to the helium internal standard and to the SRAT slurry evolved hydrogen. This could be accomplished with some dynamic process modeling. One advantage of such a model would be that it provides a mechanism for back-calculating the true generation rate free of dynamic effects. This would allow future and selected past data to be put on an apparatus dynamics free basis, i.e. make the data more directly comparable. A preliminary model was developed to answer some questions about suitable SRAT air purge rates during bench-scale tests. This model could be enhanced/refined as a predecessor to putting data from different experimental set-ups into a common basis. 


\section{Search for Statistical Correlations in the Hydrogen Generation Database}

All of the available hydrogen generation data could be entered into a single spreadsheet. Certain values could be normalized by the total sludge solids, or by total system volume, etc. Some of the data were taken under conditions that would not be described as prototypical. These data might need to be given additional analysis before they can be incorporated into the database. The data set could be subjected to a thorough search for statistically significant correlations between the variables. Presumably the obvious correlations between increased acid and increased hydrogen, increased noble metals and increased hydrogen, and so forth would show up. Other less obvious correlations might show up that suggest additional directions for experimental tests. This project could tie into generating a database of hydrogen generation rate data, as well as to reviewing hydrogen generation data from the past two years.

\section{Characterize Noble Metals During SRAT Processing}

A study on the nature of noble metal species during the SRAT (and SME) cycle is probably a required step toward gaining a fundamental understanding of hydrogen generation. Noble metals apparently are reduced from their salts or hydroxides, become active (either homogeneously or heterogeneously), and then lose activity (poisoning, agglomeration, etc.). $\mathrm{Ru}, \mathrm{Rh}$, and $\mathrm{Pd}$ may interact with silver and/or mercury and the other sludge solids.

M. C. Duff and D. B. Hunter of the SRNL have led the study of $\mathrm{Pd}, \mathrm{Ru}$, and $\mathrm{Hg}$ catalyzed decomposition of dissolved tetraphenylborate (TPB). Palladium nanoclusters were detected. Hg-Pd solids were detected. $\mathrm{Ru}(\mathrm{III})$ was detected converting to $\mathrm{RuO}_{2}$ nanoclusters. Test samples were taken to Brookhaven National Laboratory (Upton, NY) for X-ray Absorption Near-Edge Structure (XANES) and extended Xray Absorption Fine-Structure (EXAFS) spectroscopic measurements at the National Synchrotron Light Source (NSLS) facility.

A multi-method approach was required to verify the presence, size and spatial distribution of these noble metal solids. This spectroscopic work was supported with scanning electron microscopy (SEM) and high-resolution transmission electron microscopy (TEM) for spatial imaging. Time resolution would be achieved by removing SRAT sludge during a test, and preparing samples so as to quench any on-going processes. At least three months advance notice is required to obtain time at NSLS. The preparation of the samples ought to occur relatively shortly before they would be taken to Brookhaven.

The data analysis and modeling are quite involved. On the positive side, Drs. Duff and Hunter have already researched the SRS waste noble metals, obtained the relevant literature material, have comparison scans of the pure noble metals, and have generated molecular models of noble metal catalysts etc. The test could be done with simulants to establish a baseline. Testing would then need to progress to radioactive samples. The cost of the analysis increases as the number of species to be followed increases. (Nevertheless, it might make sense to list all such fundamental processing questions, e.g. the oxidation state and coordination number of manganese during reduction, dissolution of nickel during $\mathrm{pH}$ adjustment, etc. and try to get it all at once.)

\section{Develop a Model for SRAT Kinetics}

If sufficient experimental data is amassed, it might be possible to relate the SRAT processes leading to hydrogen generation to a set of series and parallel chemical reactions with appropriate kinetic constants. Models of varying sophistication are possible depending on the quality of the data and the requirements or goals for the model results. While this is a worthwhile task, it is given lower priority because it would be inefficient to take this on without completing some of the work given above. Even with the above 
proposed experimental work, it seems likely that more bench-scale SRAT cycles would be required as part of this task in order to adequately fill the outstanding gaps in knowledge before preparing a viable kinetic model.

The simplest model ought to be capable of predicting the onset and magnitude of the initial hydrogen peak as a function of the fewest possible process variables. To achieve a viable model will probably require the ability to predict solution potential as a function of starting composition and masses of acids added. A rigorous model for solution potential might not be feasible (not sure anyone has ever successfully done this for a complex system), but an empirical approach might be sufficient if the ultimate goal is hydrogen generation information.

It is too early to define the experiments for this task. The results of the other proposed work above would help in narrowing the focus. Still, it appears that testing ought to use at least two different sludge simulants, more than two acid stoichiometries, at least two levels of noble metals, possibly some variations in nitrite ion over and above the differences between the nominal sludge concentrations, etc.

\section{Summary}

A number of the above recommendations have already been integrated into a phased approach to improving understanding of catalytic hydrogen generation (as of early 2005). Others will be brought in as the program evolves. The initial follow-up phase to this review was an investigation of mercury-noble metal interactions. The second phase is an investigation on the impact of co-precipitating noble metals compared with using noble metal trim chemicals in a SRAT batch. The second phase also includes reviewing hydrogen generation data from the past three years, i.e. the data generated since this report was first drafted in 2002. 


\subsection{REFERENCES}

Baich, M. A., Summary of $1 / 200^{\text {th }}$ Scale SRAT Batches to Support the Change From Copper Formate to Copper Nitrate in Hydrolysis Operations (U). WSRC-RP-94-819, Rev. 1, Savannah River Site, Aiken, SC 29808 (September 12, 1994).

Baldauf, M. and D. M. Kolb, "Formic Acid Oxidation on Ultrathin Pd Films on Au(hkl) and Pt(hkl) Electrodes". J. Phys. Chem., 100, 11375-11381 (1996).

Bibler, N. E., T. L. Fellinger, and D. T. Hobbs, Technetium-99 Behavior in Savannah River Site High Level Waste Sludges During Waste Processing. WSRC-TR-2004-00196, Savannah River Site, Aiken, SC 29808 (April 2004).

Bibler, N. E., Measuring and Predicting Fission Product Noble Metals in Savannah River Site High Level Waste Sludges. WSRC-TR-2005-00098, Savannah River Site, Aiken, SC 29808 (February 2005).

Bickford, D. F., C. J. Coleman, C. W. Hsu, and R. E. Eibling, Control of High Level Radioactive WasteGlass Melters - Part 6: Noble Metal Catalyzed Formic Acid Decomposition and Formic Acid/Denitration (U). WSRC-MS-90-363, Savannah River Site, Aiken, SC 29808 (April 29, 1991).

Bond, G. C., Catalysis by Metals. Academic Press, New York, 1962.

Coleman, C. J., N. E. Bibler, and D. M. Ferrara, Reaction of Formic and Nitric Acids with Savannah River Site Radioactive HLW Sludge in the DWPF Pretreatment Steps. WSRC-MS-93-563, Savannah River Site, Aiken, SC 29808 (1993).

Cordi, E. M. and J. L. Falconer, "Oxidation of Volatile Organic Compounds on a Ag/A12O3 Catalyst". Applied Catalysis A: General, 151, 179-191 (1997).

Daniel, W. E., Increased CPC Batch Size Study for Tank 42 Sludge in the Defense Waste Processing Facility (DWPF) (U). WSRC-TR-00111, Rev. 0, Savannah River Site, Aiken, SC 29808 (April 6, 1999).

Daniel, W. E., Hydrogen Generation During Melter Feed Preparation of Tank 42 Sludge and Salt Washed Loaded CST in the Defense Waste Processing Facility (DWPF) (U). WSRC-TR-99-00277, Savannah River Site, Aiken, SC 29808 (August 23, 1999).

Eargle, J. C., SRAT Hydrogen Design Scoping Study. DB-90-0820, November 26, 1990 (Contains SRLPTD-90-0066, LEL Control of IDMS SRAT (U), November 2, 1990 by R. A. Jacobs.)

Fellinger, T. L., IDMS PX7 Run Plan (U). SRT-LSE-94-0169, December 5, 1994.

Fellinger, T. L., C. L. Crawford, K. M. Marshall, and N. E. Bibler, Confirmation Run of the DWPF SRAT Cycle Using the Sludge-Only Flowsheet with Tank 42 Radioactive Sludge and Frit 200 in the Shielded Cells Facility (U). WSRC-RP-98-00329, Savannah River Site, Aiken, SC 29808 (June 3, 1998).

Fellinger, T. L., C. L. Crawford, K. M. Marshall, N. E. Bibler, and T. B. Edwards, Confirmation Run of the DWPF SME Cycle Using the Sludge-Only Flowsheet with Tank 42 Radioactive Sludge and Frit 200 in the Shielded Cells Facility (U). WSRC-RP-98-00351, Savannah River Site, Aiken, SC 29808 (June 9, 1998). 
Fellinger, T. L., N. E. Bibler, J. M. Pareizs, A. D. Cozzi, and C. L. Crawford, Macrobatch 3 Acceptance Evaluation - Data from the Shielded Cells Demonstration of Defense Waste Processing Facility's Feed Preparation Cycles for Macrobatch 3 (Sludge Batch 2)(U). WSRC-RP-2001-00971, Savannah River Site, Aiken, SC 29808 (November 1, 2001).

Fellinger, T. L., J. M. Pareizs, N. E. Bibler, A. D. Cozzi, and C. L. Crawford, Confirmation Run of the DWPF SRAT Cycle Using the Sludge-Only Flowsheet with Tank 40 Radioactive Sludge and Frit 200 in the Shielded Cells Facility (U). WSRC-TR-2002-00076, Savannah River Site, Aiken, SC 29808 (2002).

Fellinger, T. L., J. M. Pareizs, N. E. Bibler, A. D. Cozzi, and C. L. Crawford, Confirmation Run of the DWPF SME Cycle Using the Sludge-Only Flowsheet with Tank 40 Radioactive Sludge and Frit 200 in the Shielded Cells Facility (U). WSRC-TR-2002-00096, Savannah River Site, Aiken, SC 29808 (2002).

Ferrara, D. M., N. E. Bibler, and B. C. Ha, Hydrogen Production During Processing of Radioactive Sludge Using the Nitric Acid-Late Wash Flowsheet. WSRC-RP-92-1137, Savannah River Site, Aiken, SC 29808 (October 13, 1992).

Ferrara, D. M., WSRC-NB-94-60, WSRC-NB-95-188, and WSRC-NB-95-373 (laboratory notebooks).

Ferrara, D. M., N. E. Bibler, M. S. Hay, B. C. Ha, and M. K. Andrews, Shielded Cells Batch 1 -Sludge Only Campaign with Tank 51 Sludge and Frit 200 (U). WSRC-TR-95-0481, Savannah River Site, Aiken, SC 29808 (December 10, 1995).

Ferrara, D. M., B. C. Ha, D. P. Lambert, and N. E. Bibler, Technical Assessment of a Sludge-Only Frit 200 Flowsheet with Copper (U). WSRC-TR-96-0142, Savannah River Site, Aiken, SC 29808 (June 7, 1996).

Ha, B. C., D. M. Ferrara, and N. E. Bibler, Hydrogen Production During Processing of Radioactive Sludge Containing Noble Metals (U). WSRC-MS-92-109, Savannah River Site, Aiken, SC 29808 (Aug. 1992).

Ha, B. C., D. M. Ferrara, and N. E. Bibler, Hydrogen Production During Processing of Radioactive Sludge Containing Noble Metals (U). WSRC-MS-92-109X, Savannah River Site, Aiken, SC 29808 (Aug. 1992).

Ha, B. C., WSRC-NB-91-142, WSRC-NB-92-138, and WSRC-NB-92-260 (laboratory notebooks).

Hay, M. S. and N. E. Bibler, Characterization and Decant of Tank 42 Sample ESP-200 (U). WSRC-RP98-00404, Rev. 0, Savannah River Site, Aiken, SC 29808 (May 28, 1998).

Hay, M. S. and N. E. Bibler, Characterization and Decant of Tank 42H Sludge Sample ESP-200 (U). WSRC-RP-98-00406, Rev. 0, Savannah River Site, Aiken, SC 29808 (June 12, 1998).

Hill, S. P. and J. M. Winterbottom, "The Conversion of Polysaccharides to Hydrogen Gas. Part I: The Palladium Catalyzed Decomposition of Formic Acid/Sodium Formate Solutions", J. Chem. Tech. Biotechnol., 41, 121, (1988).

Hsu, C. W., Hydrogen Evolution During the Formic Acid Treatment of Sludge Simulant (U). WSRC-RP90-664, Savannah River Site, Aiken, SC 29808 (July 10, 1990).

Hsu, C. W., Literature Search on Hydrogen Concern in the SRAT. SRL-PTD-90-0082, Nov. 10, 1990. 
Hsu, C. W. and J. A. Ritter, Study on Hydrogen Evolution During Treatment of SRS High Level Radioactive Sludge Simulant with Formic Acid $(U)$. WSRC-MS-92-270, Savannah River Site, Aiken, SC 29808 (August 10, 1992).

Hsu, C. W., Validation of Hydrogen Design Basis for DWPF Cold Chemical Runs with Nitric Acid and Late Washing Flowsheets (U). WSRC-RP-92-1194, Savannah River Site, Aiken, SC 29808 (September 28, 1992).

Hsu, C. W., Hydrogen Generation in SRAT with Nitric Acid and Late Washing (U). WSRC-RP-92-1213, Savannah River Site, Aiken, SC 29808 (October 26, 1992).

Hsu, C. W., Summary Report: Hydrogen Generation In SRAT with Nitric Acid and Late Washing Flowsheets (U). WSRC-RP-92-1236, Savannah River Site, Aiken, SC 29808 (October 22, 1992).

Hsu, C. W., D. M. Ferrara, N. E. Bibler, B. C. Ha, and J. A. Ritter, Development of a Nitric/Formic Acid Process to Reduce Hydrogen Emissions During Sludge Treatment in the DWPF, summary manuscript obtained a copy from D. Ferrara with no Record's number (may have some data for PX6 or PX7, though not labeled as such).

Hsu, C. W., Hydrogen Evolution Rate with the Late Wash and Nitric Acid Flowsheets (U). WSRC-TR94-0513, Savannah River Site, Aiken, SC 29808 (October 17, 1994).

Hsu, C. W., WSRC-NB-90-182, WSRC-NB-91-205, WSRC-NB-92-99 (laboratory notebooks).

Hutson, N. D., et al., Integrated DWPF Melter System (IDMS) Campaign Report: Mercury Operation (U). WSRC-TR-91-0363, Savannah River Site, Aiken, SC 29808 (1991).

Hutson, N. D., J. R. Zamecnik, M. E. Smith, D. H. Miller, and J. A. Ritter, Integrated DWPF Melter System (IDMS) Campaign Report - The First Two Noble Metals Operations (U). WSRC-TR-91-0400, Savannah River Site, Aiken, SC 29808 (June 6, 1991).

Hutson, N. D., An Evaluation of Mercury Removal in the IDMS Using the Nitric Acid Flowsheet (U). WSRC-TR-92-0492, Savannah River Site, Aiken, SC 29808 (October 22, 1992) \{covers IDMS runs HM4, PX3, PX4\}.

Hutson, N. D., Integrated DWPF Melter System (IDMS) Campaign Report: Hanford Waste Vitrification Plant (HWVP) Process Demonstration (U). WSRC-TR-92-0403, Rev. 1, Savannah River Site, Aiken, SC 29808 (June 11, 1993).

Hutson, N. D., IDMS Purex-6 Progress Report, SRTC-LSE-94-0072, March 29, 1994 (no hydrogen data).

Hutson, N. D. and J. R. Zamecnik, Integrated DWPF Melter System (IDMS) Campaign Report: IDMS Purex-6 (PX6) Operation (U). WSRC-TR-94-0556, Savannah River Site, Aiken, SC 29808 (November $15,1994)$.

Jacobs, R. A., LEL Control of IDMS SRAT(U). SRL-PTD-90-0066, November 2, 1990.

King, R. B., A. D. King, Jr., N. K. Bhattacharyya, C. M. King, and L. F. Landon, "Noble Metal Fission Products as Catalysts for Hydrogen Evolution From Formic Acid Used in Nuclear Waste Treatment", in 
Chemical Pretreatment of Nuclear Waste, W. W. Schulz and E. P. Horwitz, eds., Plenum Press, New York, 1995.

King, R. B. and N. K. Bhattacharyya, "Catalytic Reactions of Formate 4. A Nitrite-promoted Rhodium (III) Catalyst for Hydrogen Generation from Formic Acid in Aqueous Solution", Inorganica Chimica Acta, 237, 65-69 (1995).

King, R. B., N. K. Bhattacharyya, and K. D. Wiemers, "Noble Metal Catalyzed Hydrogen Generation from Formic Acid in Nitrite-containing Simulated Nuclear Waste Media”. Environ. Sci. Technol., 30, 1292-1299 (1996).

King, R. B., N. K. Bhattacharyya, H. D. Smith, and K. D. Wiemers, "Noble Metal Catalyzed Ammonia Generation by Formic Acid Reduction of Nitrate in Simulated Nuclear Waste Media", Environ. Sci. Technol., 31, 984-992 (1997).

King, R. B., N. K. Bhattacharyya, H. D. Smith, and K. D. Wiemers, "Redox Potential Monitoring as a Method to Control Unwanted Noble Metal-Catalyzed Hydrogen Generation from Formic Acid Treatment of Simulated Nuclear Waste Media", Environ. Sci. Technol., 32, 3178-3184 (1998).

Koopman, D. C. and D. P. Lambert, Hydrogen Generation and Foaming During Tests in the GFPS Simulating DWPF Operations with Tank 42 Sludge and CST $(U)$. WSRC-TR-99-00302, Rev. 1, Savannah River Site, Aiken, SC 29808 (June 20, 2001).

Koopman, D. C., Sludge Batch 2 (Macrobatch 3) Flowsheet Studies with Simulants (U). WSRC-TR2000-00398, Savannah River Site, Aiken, SC 29808 (October 9, 2000).

Koopman, D. C., Summary of Results from the Preparation of Nominal Tank 8/Tank 40 Melter Feed in the 1/240 ${ }^{\text {th }}$ Glass Feed Preparation System (U). SRT-GPD-2001-020, March 1, 2001.

Koopman, D. C. and D. H. Miller, Production of Simulated Sludge Batch 2 Melter Feed Containing Frit 320 in the 1/240 th Glass Feed Preparation System (U). WSRC-TR-2002-00186, Savannah River Site, Aiken, SC 29808 (2002).

Lambert, D. P., C. S. Boley, and J. R. Zamecnik, Alternative Tank 51 Sludge-Only Process Development for the Defense Waste Processing Facility $(D W P F)(U)$. WSRC-RP-97-40, Rev. 1, Savannah River Site, Aiken, SC 29808 (March 13, 1997).

Lambert, D. P. and C. S. Boley, Alternative Tank 51 Sludge-Only Process Development for the Defense Waste Processing Facility (DWPF) (U). (Interim Report), WSRC-RP-97-40, Rev. 0, Savannah River Site, Aiken, SC 29808 (February 12, 1997).

Lambert, D. P., WSRC-NB-97-240 (lab notebook, issued 8/12/97).

Lambert, D. P. and C. S. Boley, Tank 42 Sludge-Only Process Development for the Defense Waste Processing Facility (DWPF) (U). WSRC-RP-98-00149, Rev. 1, Savannah River Site, Aiken, SC 29808 (September 2, 1998).

Landon, L. F., Hydrogen Flammability Control in the Defense Waste Processing Facility (U). WSRCRP-91-544, Savannah River Site, Aiken, SC 29808 (May 13, 1991) \{covers IDMS runs BL1, BL2\}. 
Langowski, M. H., E. V. Morrey, J. M. Tingey, and M. R. Beckette, Offgas Characterization from the Radioactive Core Sample (102-AZ-1) and Simulant During DWVP Feed Preparation Testing: Letter Report. PNNL-11043, March 1996.

Lee, D-K. and D-S. Kim, "Catalytic Wet Air Oxidation of Carboxylic Acids at Atmospheric Pressure". Catalysis Today, 63, 249-255 (2000).

Müller, E. and W. Loerpabel, "The Catalytic Decomposition of Aqueous Solutions of Formic Acid by the Platinum Metals IV" (in German). Monatshefte für Chemie, 53, 825 (1929).

Müller, E. and H. Hentschel,, Ber. 59, 1854 (1926).

Müller, E. and F. Z. Müller, Elecktrochem., 31, 41-5 (1925).

Müller, E. and F. Z. Müller, Elecktrochem., 30, 493-7 (1924).

Ritter, J. A., N. D. Hutson, and M. E. Smith, Integrated DWPF Melter System (IDMS) Campaign Report - Coupled Feed Operation (U). WSRC-TR-90-131, Savannah River Site, Aiken, SC 29808 (March 1, 1990) \{covers IDMS runs PHA1, PHA2, PHA3\}.

Ritter, J. A., J. R. Zamecnik, and C. W. Hsu, Hydrogen Generation During Treatment of Simulated HighLevel Radioactive Waste with Formic Acid (U). WSRC-MS-92-017, Savannah River Site, Aiken, SC 29808 (April 12, 1992) \{covers IDMS runs BL1, BL2, HM2, HM3, PX1, PX2\}.

Ritter, J. A., Overview of Run Plan for IDMS PX5, SRTC-LSE-92-0037, October 6, 1992.

Ritter, J. A. and C. W. Hsu, DWPF Integrated Chemical Runs: Bench-Scale Study of Hydrogen Evolution from Formic Acid Treated Sludge Simulants $(U)$. WSRC-RP-02-1343, Rev. 1, Savannah River Site, Aiken, SC 29808 (November 30, 1992) \{bench scale support for IDMS runs BL1, HM1, PX1, PX2 and PX3\}.

Ritter, J. A., Late Wash/Nitric Acid Flowsheet Hydrogen Generation Bases for Simulation of a Deflagration/Detonation in the DWPF CPC $(U)$. WSRC-RP-93-0688, Savannah River Site, Aiken, SC 29808 (May 7, 1993) \{covers IDMS PX4, PX5\}.

Ritter, J. A., Hydrogen Generation During IDMS Demonstrations of the Late Washing and Nitric Acid Flowsheets (U). WSRC-RP-92-1237, Savannah River Site, Aiken, SC 29808 (October 19, 1992) \{covers IDMS PX4, PX5\}.

Ruthven, D. M. and R. S. Upadhye, "The Catalytic Decomposition of Aqueous Formic Acid over Suspended Palladium Catalysts”. J. Catalysis, 21, 39 (1971).

Shende, R. V. and V. V. Mahajani, "Kinetics of Wet Oxidation of Formic Acid and Acetic Acid". Ind. Eng. Chem. Res., 36, 4809-4814 (1997).

Smith, D. J. and M. S. Ortman, Effects of Mercury on the Palladium/Hydrogen Reaction, DP-MS-84-34, April 23, 1984.

Smith, M. E., et al., Checkout and Start-up of the Integrated DWPF Melter System (U). WSRC-RP-890321, Savannah River Site, Aiken, SC 29808 (1989). 
SRAT Off-gas Team, Flammability Control Design Criteria for DWPF Radioactive Operation (U). WSRC-RP-91-920, Savannah River Site, Aiken, SC 29808 (September 13, 1991) \{covers IDMS PX2\}.

Wiemers, K. D., Gas Release During Formating of a Simulated Hanford Waste Vitrification Plant Feed. PNL-SA-15965, Pacific Northwest Laboratory (1988).

Wiemers, K. D., M. H. Langowski, M. R. Powell, and D. E. Larson, Evaluation of HWVP Feed Preparation Chemistry for an NCAW Simulant_Fiscal Year 1991: Evaluation of Offgas Generation, Reductant Requirements and Thermal Stability: Technical Report. PNNL-11029, March 1996.

Wiemers, K. D., M. H. Langowski, and M. R. Powell, Detailed Design Data Package: 1.9a Measure Hydrogen Generation During Formating; 1.10a Nitrate Salt Reaction. PNNL-11049, March 1996.

(Contains same data but different discussion than PNNL-11029.)

Zamecnik, J. R., Batching for IDMS PX5 (U). SRTC-LSE-92-36, (October 6, 1992).

Zamecnik, J. R., IDMS PX5 Run Plan Notes (U). SRTC-LSE-92-35, (October 6, 1992).

Zamecnik, J. R., N. D. Hutson, M. E. Smith, D. H. Miller, and J. A. Ritter, Integrated DWPF Melter System (IDMS) Campaign Report - DWPF Cold Run Demonstrations (U). WSRC-TR-93-593, Savannah River Site, Aiken, SC 29808 (April 21, 1993) \{covers IDMS BL3 and HM1 \}.

Zamecnik, J. R., Nitric Acid Flowsheet with Late Wash PHA Testing (U). WSRC-RP-93-1039, Savannah River Site, Aiken, SC 29808 (October 28, 1993).

Zamecnik, J. R., IDMS PX6 Run Plan (U). SRT-LSE-93-0087, (November 29, 1993).

Zamecnik, J. R., Determination of Rate of Change of SME Hydrogen Evolution (U). SRT-LSE-94-102, (May 17, 1994) \{covers IDMS PX2\}. 


\section{Distribution:}

E. W. Holtzscheiter, 773-A

D. A. Crowley, 999-W

S. L. Marra, 999-W

T. B. Calloway, 999-W

N. E. Bibler, 773-A

C. M. Jantzen, 773-A

J. R. Harbour, 773-42A

G. C. Wicks, 773-A

R. E. Eibling, 999-W

M. A. Baich, 999-W

C. C. Herman, 773-42A

T. L. Fellinger, 773-A

M. E. Stone, 999-W

J. R. Zamecnik, 773-41A

J. M. Pareizs, 773-A

M. S. Miller, 704-S

J. E. Occhipinti, 704-S

R. M. Hoeppel, 704-27S

H. H. Elder, 766-H

J. F. Iaukea, 704-30S

J. W. Ray, 704-S

P. M. Patel, 704-27S

F. A. Washburn, 704-27S

M. A. Rios-Armstrong, 766-H

A. B. Sanders, 704-27S

W. B. Van-Pelt, 704-S 